
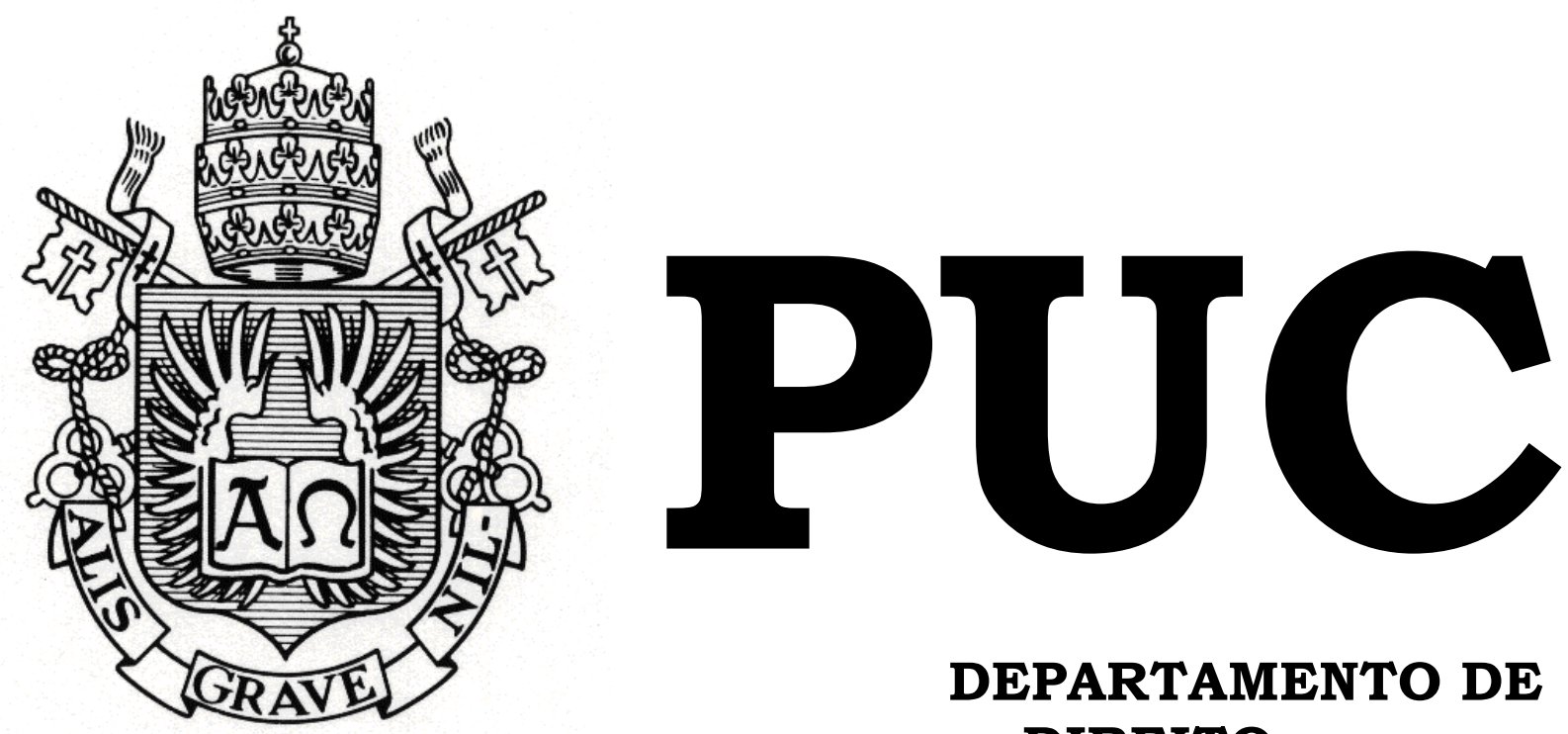

DEPARTAMENTO DE DIREITO

A exploração de oportunidade comercial pelo acionista controlador

por

Frederico Calmon Nogueira da Gama

ORIENTADOR: Marcelo Fernandez Trindade 2017.2

PONTIFÍCIA UNIVERSIDADE CATÓLICA DO RIO DE JANEIRO

RUA MARQUÊS DE SÃO VICENTE, 225 - CEP 22453-900

RIO DE JANEIRO - BRASIL 


\title{
A exploração de oportunidade comercial pelo acionista controlador
}

\author{
por \\ Frederico Calmon Nogueira da Gama
}

Monografia apresentada ao Departamento de Direito da Pontificia Universidade Católica do Rio de Janeiro (PUC-Rio) como requisito parcial para a obtenção do título de Bacharel em Direito.

Orientador: Marcelo Fernandez Trindade 


\section{AGRADECIMENTOS}

Ao final de uma das mais importantes fases na vida de uma pessoa, não posso deixar de agradecer a todos aqueles que me fizeram quem sou e sem os quais não poderia ter chegado aonde estou.

Em primeiro lugar, à minha família. À minha mãe Patricia, por ter me dado o amor e cuidado que só a melhor delas poderia oferecer. À minha irmã Bia, pela paciência e carinho com um irmão mais velho que sempre cumpriu o seu papel de importunar. E, é claro, ao meu pai Guilherme, por ser o maior espelho e exemplo para uma carreira profissional que agora se inicia.

À Veronica. A melhor companheira que nem nos melhores sonhos eu poderia imaginar ter ao meu lado. Obrigado por me proporcionar o sorriso fácil em meu rosto a cada vez que te vejo. Obrigado, ainda, pela minuciosa e fundamental revisão deste trabalho. Não teria conseguido sem você.

Às minhas avós Thereza e Mariinha, pela sabedoria e cuidado na manutenção de famílias tão unidas, independentemente das distâncias que nos separam. Aos meus tios - César, Nino, Teteia, Marcelo e Lilian - e às minhas primas - Débora, Flávia e Raffa - pelos inúmeros momentos em família.

Agradeço aos meus amigos da PUC-RIO, na figura de todos os que fizeram parte da Turma HB. Aos membros do GEADICI - Bruno, Alexandre, Pedro, Carol, Bia, Munique, Fábio, Matheus Drummond e Matheus Oberg por me proporcionarem a melhor experiência acadêmica de toda a faculdade e se tornarem, ao final de tudo, amigos para a vida toda.

Agradeço ao Marcelo Tourinho, ex-chefe e quem me trouxe a inspiração para o tema da presente monografia. Agradeço também à Julia Franco, atual chefe e fonte de aprendizado diário no Cantidiano Advogados. Não poderia deixar de também agradecer ao Dr. Cantidiano que, apesar do breve convívio, deixou sua marca brilhante na minha formação. 
Por fim, deixo registrada minha homenagem às duas pessoas que, em vida, não pouparam esforços para que eu atingisse os meus objetivos. Os valores de honestidade, solidariedade e perseverança estiveram sempre presentes nos seus ensinamentos e são a base para o homem que me tornei. Nunca esquecerei da cobrança pela excelência que deu causa à minha trajetória acadêmica até o momento. Aonde quer que estejam, sei que estarão orgulhosos por este momento. Muito obrigado, vô Tônio e vô Saint-Clair. 


\section{Resumo}

Gama, Frederico Calmon Nogueira da. A exploração de oportunidade comercial pelo acionista controlador. 97 p. Monografia (Graduação em Direito) - Pontifícia Universidade Católica do Rio de Janeiro: Rio de Janeiro, 2017

O presente trabalho tem como objetivo analisar a exploração, por parte de acionistas controladores, de oportunidades comerciais passíveis de aproveitamento pelas companhias por eles controladas. Esta monografia tratará do surgimento e desenvolvimento da corporate oportunity doctrine americana e sua compatibilidade com o regime de responsabilidades do acionista controlador à luz do ordenamento jurídico brasileiro. Será feita comparação entre a lealdade esperada de acionistas controladores e o dever fiduciário de lealdade imposto aos administradores de companhias abertas brasileiras. Será abordada, de forma crítica, a aplicação do instituto da usurpação de oportunidade comercial de acionistas controladores pela Comissão de Valores Mobiliários, com apresentação de histórico e fundamentos de cada um dos casos julgados. Por fim, serão analisados os impactos ao mercado de capitais brasileiro decorrentes da responsabilização de acionistas controladores pela utilização de oportunidades comerciais, sugerindo a correta e completa divulgação de informações como saída para a conciliação do melhor desenvolvimento do mercado de capitais brasileiro com a proteção dos acionistas minoritários.

Palavras-chave: Direito Societário - Mercado de Capitais - Corporate Oportunity Doctrine - Usurpação de Oportunidade Comercial - Acionistas Controladores - Poder de Controle - Responsabilidade Administrativa Deveres Fiduciários - Comissão de Valores Mobiliários. 


\section{Sumário}

INTRODUÇÃ $O$.................................................................................................

CAPÍTULO 1 - DEVERES E RESPONSABILIDADES DO ACIONISTA CONTROLADOR ............................................................ 12

1.1 Regime de responsabilidade do acionista controlador no Direito brasileiro 12

1.1.1 Extensão do dever de lealdade dos administradores ao Acionista Controlador 20

1.1.2 Escolha legislativa pela não repressão da usurpação de oportunidade comercial por acionistas controladores e a livre iniciativa 26

1.2 Forma de apresentação da oportunidade comercial ..............................30

CAPÍTULO 2 - CORPORATE OPPORTUNITY DOCTRINE ................36

2.1 Desenvolvimento da Corporate Opportunity Doctrine - a evolução dos testes de verificação ..................................................................................36

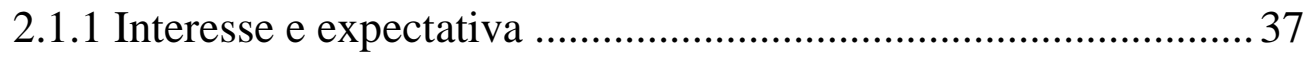

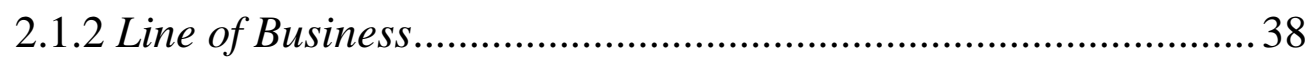

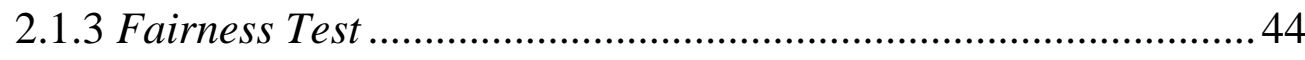

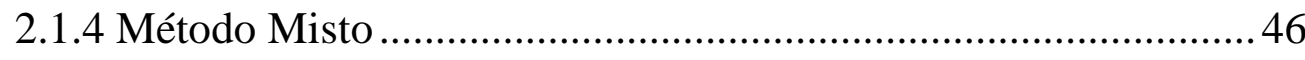

2.2 Responsabilidade do acionista controlador na corporate opportunity doctrine

CAPÍTULO 3 - APLICAÇÃO DA VEDAÇÃO À USURPAÇÃO DE OPORTUNIDADE COMERCIAL NO DIREITO BRASILEIRO .......52

3.1 Jurisprudência da Comissão de Valores Mobiliários............................52

3.1.1 Caso AMBEV (Processo CVM RJ2004/5494) .............................53

3.1.2 Caso M\&G Poliéster (PAS CVM RJ2008/1815)..........................58

3.1.3 Caso CAL (PAS CVM RJ2012/10487) …………………….......66

3.1.4 Caso Inepar (PAS CVM RJ2013/1840) ...................................... 71

3.2 Repressão por meio de Processos Administrativos Sancionadores ...74

3.2.1 Vedação à aplicação retroativa de nova interpretação em processos

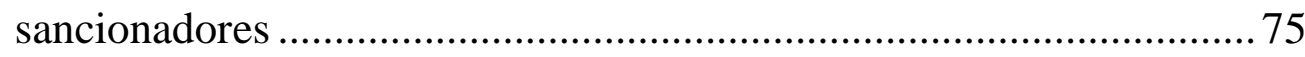

CAPÍTULO 4 - O MELHOR TRATAMENTO DA EXPLORAÇÃO DE OPORTUNIDADE PELO ACIONISTA CONTROLADOR -

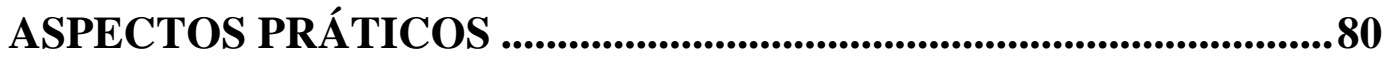

4.1 Inviabilização de modelos de negócio e o desestímulo à abertura de capital 80 
4.1.1 Indústria de private equity e venture capital................................8 80

4.1.2 Controle de riscos pelo acionista controlador .............................. 83

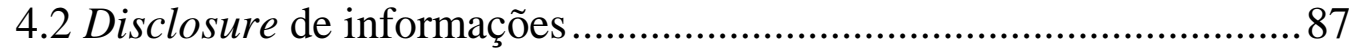

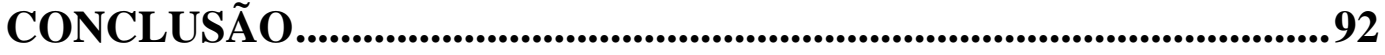

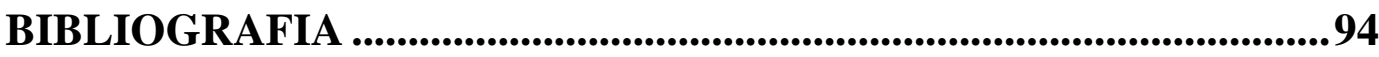




\section{INTRODUÇÃO}

Por diversas vezes a vida em sociedade mostra-se conflituosa. Apesar de o objetivo primordial e final de todos aqueles que decidem empenhar recursos e esforços no desenvolvimento de uma atividade econômica ser sempre o mesmo - a obtenção de lucro -, os meios e as decisões tomadas para a satisfação deste objetivo são o pano de fundo para as maiores discussões societárias.

Ainda que pareçam mais comuns, os conflitos societários não são exclusividade daquelas empresas formadas por um pequeno grupo de sócios, muitas vezes familiares, que trazem para dentro do negócio conflitos advindos de suas relações interpessoais. As sociedades anônimas, comumente marcadas pela falta de relacionamento interpessoal ou relevância entre cada um os acionistas, também passam por profundos conflitos que acabam afetando a condução ideal dos negócios.

Nos casos de sociedades anônimas, especialmente as de capital aberto, é cada vez mais comum o ativismo de acionistas minoritários que, inconformados com decisões negociais impostas exclusivamente pelos acionistas controladores, fazem de tudo para obstaculizar operações com as quais não concordam e buscam a tutela judicial, arbitral ou mesmo administrativa (no caso das companhias abertas, reguladas pela Comissão de Valores Mobiliários) para ver satisfeitos os seus interesses.

No mercado de capitais brasileiro, em razão de seu estágio de desenvolvimento ainda incipiente em relação a mercados mais antigos e robustos como o europeu ou o norte-americano, a figura do acionista controlador recebe grande importância na condução das atividades de companhias abertas, sendo observada a presença de controladores bem 
delimitados na grande maioria das companhias com valores mobiliários admitidos à negociação em nosso país. ${ }^{1}$

Por ser o acionista controlador aquele titular de direitos de sócios que lhe assegurem, de modo permanente, a maioria os votos nas deliberações da assembleia geral e o poder de eleger a maioria dos administradores, com o uso efetivo de seu poder para dirigir as atividades sociais e orientar o funcionamento dos órgãos sociais, é comum que a grande maioria das decisões de competência da Assembleia Geral esteja nas mãos deste acionista ou grupo de acionistas.

E mais. O acionista controlador, em razão de sua capacidade de escolha da maioria dos componentes da administração das companhias, acaba também influenciando indiretamente as decisões que não são de competência dos acionistas, mas destes órgãos da administração. ${ }^{2}$

Junto com o poder de controle e os direitos dele advindos, a legislação brasileira conferiu ao acionista controlador deveres e responsabilidades para com a companhia, os demais acionistas da empresa, os que nela trabalham e para com a comunidade em que atua, cujos direitos e interesses deve lealmente respeitar e atender.

\footnotetext{
${ }^{1}$ Segundo dados apurados na $11^{\mathrm{a}}$ edição do Estudo A Governança Corporativa e o Mercado de Capitais elaborado pela KPMG para o período entre 2016 e 2017, 75\% das companhias abertas brasileiras possuem controle majoritário ou compartilhado. Disponível em $<$ https://assets.kpmg.com/content/dam/kpmg/br/pdf/2016/12/br-estudo-governanca-corporativa2016-2017-11a-edicao-final.pdf $>$. Acesso em: 06 de novembro de 2017.

${ }^{2}$ Sobre o papel do acionista controlador e sua influência sobre os órgãos da administração: "Na companhia em que a Assembleia Geral não exerce todo o poder que a Lei lhe confere, ou que não tem acionista controlador, o Conselho de Administração detêm, de fato, o poder supremo na direção das atividades sociais e fixa a orientação geral dos negócios da companhia, com fundamento do disposto no inciso I do artigo 142; mas se a Assembleia Geral exerce seus poderes de decidir todos os negócios relativos ao objeto social e tomar as resoluções que julgar convenientes à sua defesa e desenvolvimento (art. 121), ou se a companhia tem acionista controlador que usa do poder, que the reconhece o artigo 116, de dirigir as atividades sociais e orientar o funcionamento dos órgãos da companhia, o Conselho de Administração não tem autonomia para fixar soberanamente a orientação geral dos negócios da companhia, pois somente exerce a atribuição do inciso I do artigo 142 segundo a orientação definida pela Assembleia ou pelo acionista controlador.

A mesma observação cabe em relação às demais atribuições legais do Conselho de Administração. Não faz sentido sustentar, por exemplo, que o Conselho de Administração tem autonomia para eleger e destituir diretores, fixar sua remuneração, convocar a Assembleia Geral ou emitir ações e bônus de subscrição (se a companhia tem capital autorizado) contrariando as instruções recebidas do acionista controlador”. (LAMY FILHO, Alfredo. PEDREIRA, José Luiz Bulhões. Direito das Companhias. $2^{\mathrm{a}}$ ed. Rio de Janeiro: Forense, 2017).
} 
Em razão deste regime de responsabilidade imposto aos acionistas controladores, surgiu no Brasil uma discussão acerca da abrangência destes deveres com relação à utilização, por parte do acionista controlador, de oportunidades comerciais que, em princípio, poderiam ser exploradas pelas companhias por eles controladas.

Estão os acionistas controladores obrigados a apresentar à companhia que controlam as oportunidades por ele desenvolvidas ou a ele oferecidas fora do âmbito da companhia? É possível a responsabilização de acionistas controladores por usurpação de oportunidade comercial? A lealdade esperada dos acionistas controladores é a mesma incidente sobre os administradores de companhias? A situação do acionista controlador é diferente quando ele atua também em cargos de administração da companhia?

É a partir destes questionamentos que a usurpação de oportunidade comercial por parte de acionistas controladores passou a ser aventada e questionada por acionistas minoritários em casos concretos envolvendo companhias abertas brasileiras.

O fundamento para as reclamações e processos administrativos instaurados pela Comissão de Valores Mobiliários foi, desde os primórdios, a chamada corporate opportunity doctrine americana, que analisava a conduta de administradores de companhias americanas que utilizavam, em benefício próprio, oportunidades que poderiam ser desenvolvidas pela companhia.

Para os defensores de que a responsabilidade por usurpação de oportunidade comercial também engloba os acionistas controladores, a lealdade que se espera destes acionistas à luz do Direito brasileiro seria a mesma imposta aos administradores por força de seu dever fiduciário legalmente previsto.

Neste sentido, a corporate opportunity doctrine se aplicaria também aos acionistas controladores no Brasil, ensejando a possibilidade de 
responsabilização destes por usurpação de oportunidades comerciais de suas controladas.

O Capítulo 1 desta monografia analisará o regime de responsabilidades do acionista controlador no ordenamento jurídico brasileiro e os deveres a ele impostos. Este Capítulo também terá por objeto estudar a possível existência de deveres fiduciários do acionista controlador, especialmente a possibilidade de se estender a ele o regime imposto aos administradores quanto ao dever de lealdade.

A corporate opportunity doctrine americana é utilizada pela maior parte da doutrina brasileira e por alguns dos precedentes julgados pela Comissão de Valores Mobiliários - CVM como fundamento para a vedação à usurpação de oportunidade comercial por parte de acionistas controladores, razão pela qual o Capítulo 2 da presente monografia analisará justamente a origem e desenvolvimento da corporate opportunity doctrine.

Serão analisadas as fases de evolução da doutrina americana, passando pelas diferentes propostas de testes de verificação da conduta dos administradores e descrevendo em detalhes os casos paradigmáticos que nortearam tal evolução.

Por sua vez, o Capítulo 3 estudará a aplicação da vedação à usurpação de oportunidades comerciais aos acionistas controladores pelas autoridades brasileiras, notadamente pela Comissão de Valores Mobiliários - CVM. Serão analisados todos os casos já julgados pela CVM sobre o assunto e o fundamento na corporate opportunity doctrine para a repressão desta prática.

Também será feita análise crítica da utilização do processo administrativo sancionador como meio utilizado pela CVM para a repressão da usurpação de oportunidade comercial por acionistas controladores, apresentando suposta violação ao princípio da vedação à aplicação retroativa de nova interpretação em processos sancionadores.

O Capítulo 4, e último, apresentará proposta para o correto tratamento a ser dado sobre o aproveitamento de oportunidade comercial por parte do 
acionista controlador, indicando a melhora da qualidade informacional como o melhor tratamento para a proteção dos acionistas minoritários.

Por fim, tentar-se-á demonstrar os efeitos negativos, para o mercado de capitais brasileiro, da forma como a CVM vem atuando na repressão desta prática, com o desestímulo à abertura de capital e a inviabilização de modelos de negócios baseados na exploração de novos projetos fora do âmbito de companhias abertas. 


\section{CAPÍTULO 1 - DEVERES E RESPONSABILIDADES DO ACIONISTA CONTROLADOR}

Como não poderia deixar de ser, a análise da legalidade da exploração de oportunidades comerciais por acionistas controladores passa pelo estudo do regime de responsabilidade destes agentes no âmbito do ordenamento jurídico brasileiro.

É preciso entender o papel desenvolvido pelo acionista controlador nas companhias brasileiras e os deveres a que este acionista está sujeito, a fim de concluir se o mesmo deve ou não ser responsabilizado por não apresentar à companhia oportunidade comercial que desenvolveu ou que the foi oferecida.

\subsection{Regime de responsabilidade do acionista controlador no Direito brasileiro}

O regime de responsabilidade do acionista controlador no ordenamento jurídico brasileiro é fundado na Lei das Sociedades por Ações ("LSA"). A interpretação dos dispositivos atinentes a esse regime, essencialmente os arts. 116 e 117 da lei, mostra que o legislador teve clara preocupação com a atuação da empresa no meio em que está inserida.

O fundamento para a responsabilidade do acionista controlador está na obrigação de exercer o seu poder de controle de forma a fazer com que a companhia realize o seu objeto social e cumpra sua função social, respeitando os interesses de todos que, de certa forma, sejam impactados pelas atividades por ela desempenhadas.

É com esta preocupação que foi pensado o parágrafo único do art. 116 da LSA, base legal para todo o regime de responsabilidade do acionista controlador:

Parágrafo único. O acionista controlador deve usar o poder com o fim de fazer a companhia realizar o seu objeto e cumprir sua função social, e tem deveres e 
responsabilidades para com os demais acionistas da empresa, os que nela trabalham e para com a comunidade em que atua, cujos direitos e interesses deve lealmente respeitar e atender. ${ }^{3}$

A comprovação da intenção do legislador com este regime está na exposição de motivos da LSA, que assim dispõe:

O princípio básico adotado pelo Projeto, e que constitui o padrão para apreciar o comportamento do acionista controlador, é o de que o exercício do poder de controle só é legítimo para fazer a companhia realizar o seu objeto e cumprir sua função social, e enquanto respeita e atende lealmente aos direitos e interesses de todos aqueles vinculados à empresa - os que nela trabalham, os acionistas minoritários, os investidores do mercado e os membros da comunidade em que atua. ${ }^{4}$

Resta claro, portanto, que o legislador pensou no acionista controlador como titular de direitos e obrigações diferentes dos demais acionistas da Companhia.

A instituição de um acionista controlador titular de direitos e obrigações específicas, diferentes dos demais acionistas, modificou o critério de controle antes utilizado pelo Decreto-Lei $n^{\circ} 2.627$, de 1940. De acordo com o diploma legal de 1940, as responsabilidades específicas eram previstas apenas para os administradores e prevalecia, quantos aos acionistas, o critério do acionista majoritário ${ }^{5}$.

Na mesma linha, o eminente Professor Fábio Konder Comparato comenta a inovação de nossa Lei de Sociedades por Ações com relação aos diplomas legais anteriores em nossa legislação:

A nova lei de sociedades por ações, preenchendo sensível lacuna do direito anterior, colocou o poder de controle no centro da economia societária. Superou, com isto, a persistente ficção do anonimato acionário. Doravante, reconhecem-se os títulos de poder, no seio das companhias; aceita-se o direito

\footnotetext{
${ }^{3}$ Lei n. 6.404, de 15 de dezembro de 1976. Dispõe sobre as Sociedades por Ações. Disponível em:<http://www.planalto.gov.br/ccivil_03/leis/L6404consol.htm>. Acesso em: 07 nov. 2017.

${ }^{4}$ Exposição de motivos n. 196, de 24 de junho de 1976, do Ministério da Fazenda. Disponível em: http://www.cvm.gov.br/export/sites/cvm/legislacao/leis-decretos/anexos/EM196-Lei6404.pdf. Acesso em: 07 nov. 2017

${ }^{5}$ CARVALHOSA, Modesto. Comentários à lei de sociedades anônimas, $2^{\circ}$ volume: artigos 75 a 137. $4^{\mathrm{a}}$ ed. São Paulo: Saraiva, 2008, p 475.
} 
de comandar, como direito-função, a ser exercido em proveito da empresa como todo, e da comunidade em que atua, com a fixação de deveres e responsabilidades do controlador (Lei $\mathrm{n}^{\circ} 6.404$, de 1976 , arts. 116 e 117). ${ }^{6}$

Com a mudança legislativa, ao efetivamente exercer o poder de controle de uma companhia, o acionista controlador garante o direito de dirigir os negócios sociais, prevalecer em todas as deliberações tomadas em assembleia geral e eleger a maioria dos administradores.

\section{A aquisição destes direitos gera um valor para a posição ocupada por} um controlador de companhia, valor este incorporado às ações de titularidade do acionista controlador ${ }^{7}$. É por isso que operações de aquisição de controle acionário de empresas passam invariavelmente pelo pagamento de um valor adicional a cada ação, o chamado "prêmio de controle". 8

\section{O Professor Fábio Konder Comparato bem explicou esta relação} havida nas transferências de controle:

Estamos, portanto, muito longe dos direitos patrimoniais clássicos do acionista, consistentes na participação nos lucros e no acervo social líquido.

\footnotetext{
${ }^{6}$ COMPARATO, Fábio Konder. Ensaios e Pareceres de direito empresarial. Rio de Janeiro: Forense, 1978, p. 105.

${ }^{7}$ Sobre a avaliação do controle de uma empresa, leciona o Prof. Comparato:"Mas é óbvio que a avaliação do controle de uma empresa não se estabelece, apenas, em função dos elementos identificáveis do seu patrimônio, sejam eles tangíveis ou intangíveis. Ele representa, antes de tudo, uma situação ou status de poder na empresa e, muita vez, através dela, no mercado; posição de dominação essa, que não se reduz a bens contabilizáveis. Como salientou um autor norte-americano, repetindo praticamente os termos de um julgado, "o poder de controlar a eleição de administradores e, portanto, de gerir e controlar os bens, negócios e o comércio de uma grande companhia, de decidir sobre as diretrizes de sua política empresarial e o dispêndio de grandes somas de dinheiro, de indiretamente nomear e fixar a remuneração de seus prepostos e representantes, é um bem valioso ou poder de grande valor, mesmo se a companhia se encontra apenas em situação de pagar salários e não dividendos." Daí por que, no dizer de um técnico em avaliações, cuidando-se da aquisição do controle de uma sociedade, "já não se trata apenas de um investimento em valores mobiliários (placement) mas da aquisição de uma influência preponderante na administração e na gestão da sociedade. Por conseguinte, muito mais que a cotação de Bolsa, é o interesse apresentado para o adquirente pela finalidade da operação que irá determiná-lo, quando se tratar de oferecer ou de aceitar um preço.” (COMPARATO, Fábio Konder. Ensaios e Pareceres de direito empresarial. Rio de Janeiro: Forense, 1978, p. 107).

${ }^{8}$ Comentando a especificidade das ações detidas pelo acionista, Modesto Carvalhosa afirma: "E, além disso, revestem-se as ações de controle de um ganho de valor em face das ações minoritárias. Nesse sentido, prevê a Lei Societária a obrigação dos adquirentes dessas mesmas ações de controle de ofertar aos minoritários votantes a aquisição de suas ações por valor correspondente a $80 \%$ do respectivo preço de transação de transferência de controle efetivada. A Lei Societária, assim, reconhece que o poder de controle possui um valor intangível, que não é atribuído às ações minoritárias. (CARVALHOSA, Modesto. KUYVEN, Luiz Fernando Martins. Tratado de Direito Empresarial: Volume III - Sociedades Anônimas. São Paulo: Revista dos Tribunais, 2016, p. 544.)
} 
Distintamente dessa situação de mera fruição, o controle societário encontra, no mercado, um valor próprio e não desprezível.

A Lei $n^{\circ} 6.404$ levou em consideração esse valor próprio do controle em mais de uma norma.

Assim foi, por exemplo, em matéria de cessão de controle. É fato de observação corriqueira que o preço unitário da venda de $51 \%$ das ações votantes de uma companhia é sempre superior ao da cessão de $49 \%$ dessas ações. Nesta, levase em consideração, essencialmente, o valor de mercado das ações, a sua cotação bolsística e, secundariamente, o seu valor contábil; em suma, estimase o valor dos títulos, considerados em si mesmo. Na primeira hipótese, ao contrário, o valor de Bolsa das ações nem chega a ser considerado no negócio. A fixação do preço é feita em função do valor real do patrimônio da sociedade emitente, do setor em que se desenvolve a atividade empresarial; ou seja, avalia-se a empresa como um going concern, como dizem os norteamericanos, e não, simplesmente, o valor de liquidação do patrimônio social. Por isso mesmo, ao contrário do que ocorre na venda pura e simples de ações, nos negócios de cessão de controle as partes costumam estipular que o cedente responde pelo ativo e passivo da companhia, espelhado no balanço; pela integridade do ativo, pela veracidade do passivo. ${ }^{9}$

Concomitantemente aos direitos e poderes adicionais advindos da posição de acionista controlador, este acionista ou grupo de acionistas assume obrigações e responsabilidades para com a própria companhia e com todos que estejam, de certa forma, a ela ligados.

Tais obrigações decorrem do fato do acionista controlador ser capaz de tomar decisões que influenciarão na direção dos negócios sociais tendo, portanto, reflexos não somente no investimento dos demais acionistas, mas também na vida dos funcionários e de todos aqueles que mantém qualquer tipo de relação com a companhia ${ }^{10}$.

\footnotetext{
${ }^{9}$ COMPARATO, Fábio Konder. Ensaios e Pareceres de direito empresarial. Rio de Janeiro: Forense, 1978, pp. 105 e 106.

${ }^{10}$ Ao comentar sobre o legítimo exercício do poder de controle, Fábio Konder Comparato e Calixto Salomão Filho classificam as finalidades do exercício do poder de controle em intra ou extraempresariais: "De qualquer forma, tratando-se de abuso do poder de controle na sociedade anônima, importa definir, preliminarmente, essa finalidade ou objetivo que legitima o exercício do poder. $\mathrm{Na}$ verdade, seria mais correto falar no plural em finalidades ou objetivos, pois eles são de duas ordens: os intra e o extra-empresariais. Os primeiros correspondem à satisfação dos interesses de todos os participantes na empresa: acionistas, titulares de outros valores mobiliários emitidos pela companhia, empregados, administradores. Quanto aos interesses extra-empresariais, eles dizem respeito à comunidade local, regional ou nacional, em que se insere a empresa." (COMPARATO, Fábio Konder. SALOMÃO FILHO. Calixto. O poder de controle na sociedade anônima. Rio de Janeiro: Ed. Forense, 2008. pp. 364 e 365)
} 
A imposição destas obrigações e responsabilidades é, primordialmente, forma de proteção aos acionistas minoritários, uma vez que obriga a atuação do controlador em prol do interesse social, e não apenas de seu interesse individual.

Os autores do anteprojeto que resultou na Lei das Sociedades por Ações, Alfredo Lamy Filho e José Bulhões Pedreira, comentam a evolução desta proteção à minoria e o processo de subordinação do princípio majoritário ao interesse social:

O problema da proteção à minoria não foi tratado nas primeiras leis de anônimas. Assim, a lei francesa, de 1867, não cogitava do assunto: - seu artigo 28 consagrava o princípio do majoritário sem limitações. Como observa René David (1929, p.16) o intuitus pecuniae era da essência das companhias, e a subordinação, nas assembléias, do mais fraco ao mais forte, era a conseqüencia lógica dessa concepção.

\section{$[\ldots]$}

A primeira e óbvia limitação foi a exigência de um quorum mínimo para certas deliberações, o que estendia o poder de negociação da minoria, que passou a dispor de um poder de veto. Correlatamente, passava-se ao reconhecimento da existência, no estatuto, de cláusulas e condições excluídas da soberania das assembléias, por dizerem respeito a direitos intangíveis dos acionistas - tais como o direito à participação nos lucros e ao reembolso do capital na hipótese de dissolução da sociedade, direito de fiscalizar a sociedade, de participar do Conselho Fiscal (acionista dissidente) ou dos conselhos de administração (voto múltiplo), de pedir exibição de livros, em certos casos etc.

Além da ressalva desses direitos básicos e intocáveis, a jurisprudência dos países, em geral, evoluiu para considerar que as deliberações da assembleia teriam que ser tomadas tendo em vista o interesse da sociedade, como um todo, e não o da maioria. Mais ainda, deveria ela agir de boa-fé - requisito de todo contrato, mas particularmente exigível na sociedade. Daí, a violação desse dever resultar na anulabilidade da deliberação da assembléia por abuso de direito. ${ }^{11}$ (grifos nossos)

Ainda sobre o regime presente no art. 116, parágrafo único, da Lei de Sociedade por Ações, o legislador exigiu que os acionistas controladores não apenas façam com que a companhia cumpra seu objeto social, mas também

11 LAMY FILHO, Alfredo. PEDREIRA, José Luiz Bulhões. A lei das S.A.: (pressupostos, elaboração, aplicação). Rio de Janeiro: Renovar, 1997, pp. 77 e 78. 
sua função social. A esse respeito, a doutrina ainda diverge acerca do conceito de função social, como se pode extrair das lições dos Professores Alfredo Lamy Filho e José Bulhões Pedreira:

Sobre a matéria, os estudiosos ainda estão divididos por pontos de vista diversos. Entendem uns que as esferas pública e privada têm funções distintas; os administradores da empresa privada devem esforçar-se por manter a lucratividade no máximo, embora sem prejudicar suas obrigações contratuais para com os empregados, consumidores, credores e o meio ambiente.

Num ângulo ainda estritamente societário, arguem, outros, que a destinação de uma parcela de lucros da companhia para o benefício geral, ou o atendimento de finalidades de ordem pública, significa, a longo prazo, uma maximização de lucros da empresa; assim, o elemento de interesse público, que existe na atividade empresarial, identifica-se, de maneira geral, com os estritos interesses privados de sobrevivência e expansão das empresas. ${ }^{12}$

Desviando de tal controvérsia, que não é objeto do presente estudo, fato é que o legislador mostrou clara preocupação com o interesse das minorias.

Entendendo que a posição ocupada pelos acionistas controladores tem reflexo nos demais agentes relacionados à companhia, o legislador inseriu um dever de lealdade aos controladores, dever este que, entretanto, não pode ser confundido com o dever fiduciário de lealdade imposto aos administradores destas mesmas companhias.

A diferenciação entre essas duas espécies de lealdade será melhor estudada no item 1.1.1 abaixo.

Esta opção legislativa pelo interesse social não pressupõe que o acionista controlador deixe de perquirir o seu objetivo individual e primordial - que é a busca do lucro - mas que esse acionista paute suas decisões baseado não apenas nesse interesse, mas nos interesses da própria companhia e da comunidade em que ela atua, englobando demais acionistas, funcionários ou

\footnotetext{
${ }^{12}$ LAMY FILHO, Alfredo. PEDREIRA, José Luiz Bulhões. Direito das Companhias. $2^{\mathrm{a}}$ ed. Rio de
} Janeiro: Forense, 2017, pp. 608 e 609. 
mesmo pessoas afetadas pelo desenvolvimento de suas atividades. Neste sentido afirmam os autores da LSA:

O acionista controlador tem o dever legal de fazer com que a companhia, além de realizar seu objeto (que é explorar atividade de produção e venda de bens e serviços com o fim de obter resultados e distribuí-los aos acionistas), cumpra sua função social (art. 116, par. único). A companhia, como toda sociedade empresária e todo empresário individual, exerce a função de criar, expandir e dirigir empresa e prover o capital de risco de que necessite, e a empresa é instituição fundamental na organização econômica e social das economias de mercado. A função precípua da empresa é produzir bens econômicos, mas devido às suas características, desempenha funções tanto na produção quanto na circulação econômica e na repartição de renda, $e$ de agente da poupança e do investimento (v. $§ 13) .{ }^{13}$

Os Professores Alfredo Lamy Filho e José Luiz Bulhões Pedreira, ainda comentando a evolução da proteção às minorias nas principais legislações societárias ao redor do mundo, começam a descrever o que se entende por responsabilidade do controlador por abuso do poder de controle:

\begin{abstract}
No que toca às assembleias gerais, as reformas mantiveram a defesa da minoria na base do abuso do direito como causa da anulabilidade da assembléia. Procuraram, além disso, caracterizar a responsabilidade do "acionista dominante" (como diz a jurisprudência americana) ou controlador, que, pode condicionar a ação da sociedade, a conduz, muita vez, a decisões de seu interesse mas que violam direito da minoria, por não coincidirem com o interesse da sociedade. ${ }^{14}$
\end{abstract}

Seguindo tal evolução, a Lei das Sociedades por Ações, após a delimitação do comportamento esperado e dos deveres imputados aos acionistas controladores, passa a tratar da responsabilidade destes acionistas por exercício abusivo de seu poder de controle.

Segundo a doutrina majoritária brasileira, a infração ao dever de lealdade, que leva à responsabilização por abuso do poder de controle, é caracterizada quando o acionista controlador utiliza de seu poder de controle

\footnotetext{
${ }^{13}$ LAMY FILHO, Alfredo. PEDREIRA, José Luiz Bulhões. Direito das Companhias. $2^{\mathrm{a}}$ ed. Rio de Janeiro: Forense, 2017, p.607.

${ }^{14}$ LAMY FILHO, Alfredo. PEDREIRA, José Luiz Bulhões. A lei das S.A.: (pressupostos, elaboração, aplicação). Rio de Janeiro: Renovar, 1997, p. 80.
} 
para satisfazer interesses pessoais, em detrimento do interesse da sociedade 1516

Nota-se que o artigo 117 complementa a regra geral contida no art. 116, parágrafo único, enumerando hipóteses em que o desrespeito aos deveres e responsabilidades do controlador configurará abuso do poder de controle. 17

As hipóteses de abuso do poder de controle previstas na lei são meramente exemplificativas, uma vez que seria impossível para o legislador da época prever todas as situações em que a atuação do controlador estará infringindo o regime genérico previsto no art. 116, parágrafo único. Cabe, portanto, ao intérprete da lei apurar, no caso concreto, se a atuação do acionista controlador configura abuso do poder de controle.

\footnotetext{
${ }^{15}$ Sobre a sobreposição de interesses pessoais do controlador ao interesse social se posiciona Modesto Carvalhosa: "A regra fundamental que decorre do parágrafo único do art. 116 da Lei Societária é que não poderão os controladores buscar os interesses pessoais na condução da companhia em detrimento dos interesses desta e dos de seus acionistas minoritários. Trata-se do dever de lealdade, que constitui princípio positivado de ampla aplicação aos casos concretos e de fácil ajustamento às situações factuais de antijuridicidade, detectáveis, a todo o tempo, no exercício do poder-dever de controle acionário." (CARVALHOSA, Modesto. KUYVEN, Luiz Fernando Martins. Tratado de Direito Empresarial: Volume III - Sociedades Anônimas. São Paulo: Revista dos Tribunais, 2016. p. 548).

${ }^{16}$ Os Professores Alfredo Lamy Filho e José Luiz Bulhões Pedreira descrevem o que leva o acionista controlador à prática abusiva deste poder-dever: "O abuso do poder de controle é mais frequente, mais sutil e mais prejudicial à minoria do que o abuso do direito de voto pela maioria eventual. Dispondo do comando permanente da máquina social, elegendo ou destituindo os administradores, transformando interesses próprios e desejos individuais em deliberações assembleares, e complementando-as com atos administrativos, usando a sociedade como bem seu para obter ou trocar favores - o acionista controlador, muita vez, é induzido, pelas facilidades que se lhe abrem, a confundir o interesse próprio com o da sociedade que domina. Julga-se ser a própria companhia, ao exercer o "poder soberano", como diz COMPARATO, implantando, com frequencia, a "tirania da maioria"m irresponsável perante os demais acionistas, e tentando todos os expedientes e aventuras para conservar ou ampliar seu poder." (LAMY FILHO, Alfredo. PEDREIRA, José Luiz Bulhões. Direito das Companhias. $2^{\mathrm{a}}$ ed. Rio de Janeiro: Forense, 2017, p 611).

${ }^{17}$ Exemplo doutrinário desta tese é dado por Fran Martins, que afirma: "Visando tornar efetivas essas responsabilidades, a lei enumera, exemplificativamente, atos que, praticados pelo acionista controlador, constituem modalidades de abuso de poder, fazendo-o responder por perdas e danos causados em decorrência desses atos. Assim, em primeiro lugar devem ser respeitados e atendidos os direitos e interesses dos demais acionistas (art. 116, parágrafo único)" (MARTINS, Fran. Direito Societário: estudos e pareceres. Rio de Janeiro: Ed. Forense, 1984. pp. 33 e 34). No mesmo sentido, Modesto Carvalhosa reforça a relação entre os arts 116 e 117, apesar de defender um dever fiduciário ao controlador inexistente na LSA: "o abuso de poder se verifica pela quebra do dever fiduciário instituído no parágrafo único do art. 116”. (CARVALHOSA, Modesto. KUYVEN, Luiz Fernando Martins. Tratado de Direito Empresarial: Volume III - Sociedades Anônimas. São Paulo: Revista dos Tribunais, 2016. p. 560).
} 
Delimitados os contornos do regime de responsabilidade do acionista controlador, passaremos ao estudo detido da utilização de oportunidades comerciais por parte deste acionista.

\subsubsection{Extensão do dever de lealdade dos administradores ao Acionista Controlador}

Como será demonstrado no Capítulo 3 abaixo, na análise da utilização de oportunidade comercial por acionistas controladores, a doutrina brasileira e a jurisprudência da Comissão de Valores Mobiliários se utilizam da corporate opportunity doctrine americana para sustentar a responsabilidade dos acionistas controladores brasileiros.

Entretanto, observar-se-á no Capítulo 2 que a doutrina americana foi pensada e é aplicada para a usurpação de oportunidade comercial por parte de administradores da companhia, e não de acionistas controladores.

O principal argumento da corrente doutrinária brasileira que se debruçou sobre o tema, e que defende a responsabilidade de acionistas controladores por usurpação de oportunidade comercial à luz do Direito brasileiro, é a de que o mercado de capitais brasileiro ainda é extremamente baseado na figura do acionista controlador, diferentemente do mercado americano.

Enquanto nos Estados Unidos a grande maioria das companhias teria seu capital disperso, levando a um poder muito maior concentrado nas mãos dos administradores, no Brasil este poder estaria nas mãos dos acionistas controladores, com um mercado de capitais ainda em estágio de desenvolvimento e, portanto, com a maioria das companhias com poder de controle bem definido.

Neste sentido:

Uma distinção fundamental entre a estrutura de controle da maioria das companhias brasileiras em relação a de outros países, como os Estados Unidos, é a concentração de poder, aqui, na figura do acionista controlador com o chamado controle majoritário. Ele contrasta com o poder exercido pelos 
administradores, nas sociedades onde há uma larga dispersão acionária, como é o caso de algumas poucas companhias brasileiras e numerosas companhias norte-americanas.

Não é de se surpreender, portanto, que se dê maior importância à fiscalização dos deveres fiduciários daqueles que detêm o poder de controle: aqui, os acionistas majoritários; lá, os administradores da companhia. ${ }^{18}$

A premissa utilizada por estes autores não poderia estar mais correta. Conforme mencionado na introdução a esta monografia, $75 \%^{19}$ das companhias abertas brasileiras possuem controle majoritário ou compartilhado. Sem dúvidas, isso é reflexo de um mercado de capitais brasileiro que ainda engatinha quando comparado aos mercados mais desenvolvidos, mas que aos poucos mostra uma evolução e superação desta realidade ${ }^{20}$.

Não obstante, a conclusão chegada por estes autores e, determinadas vezes, também pela Comissão de Valores Mobiliários (conforme será estudado no Capítulo 3 abaixo) é equivocada.

Por esta linha de raciocínio, os controladores exercem, no Brasil, o papel dos administradores no mercado de capitais americano e, portanto, a eles deve ser estendido todo o padrão de lealdade exigido dos administradores.

Parece que a intenção do legislador não foi esta.

\footnotetext{
${ }^{18}$ CLAUDINO, Felipe Demori. BULHÕES, Francisco Simsen. A usurpação de oportunidade comercial pelo acionista controlador: uma abordagem prática. In: HANSZMANN, Felipe (Org.). Atualidades em Direito Societário e Mercado de Capitais $1^{\text {a }}$ ed. Rio de Janeiro: Lumen Juris, 2016, p. 101.

${ }^{19}$ Dados extraídos da $11^{\mathrm{a}}$ edição do Estudo "A Governança Corporativa e o Mercado de Capitais" elaborado pela KPMG para o período entre 2016 e 2017. Disponível em https://assets.kpmg.com/content/dam/kpmg/br/pdf/2016/12/br-estudo-governanca-corporativa2016-2017-11a-edicao-final.pdf . Acesso em: 06 de nov. 2017.

${ }^{20}$ Conforme notícia publicada pela revista Capital Aberto em 01 de agosto de 2013, já naquele ano o Brasil apresentava queda no percentual de companhias com controle definido, segundo estudo elaborado pelo CFA Institute. Notícia disponível em: https://capitalaberto.com.br/temas/gestao-derecursos/controle-definido-cai-em-brasil-china-turquia-e-taiwan/\#.WgBZu7pFzIW . Acesso em: 06. nov. 2017.
} 
Certamente, o legislador pensou no acionista controlador brasileiro como titular de um dever de lealdade para com os acionistas e a comunidade em que a companhia atua ${ }^{21}$, como se depreende da leitura do parágrafo único do art. 116 e da Exposição de Motivos da LSA:

f) atento ao fato básico de que as instituições mercantis - sobretudo na escala que a economia moderna lhes impõe - revestem-se de crescente importância social, com maiores deveres para com a comunidade em que vivem e da qual vivem, o Projeto introduziu o fato novo do dever de lealdade dessas instituições, imposto como norma de comportamento a controladores e administradores, para com o país; nesse dever estão igualadas empresas nacionais ou estrangeiras que aqui funcionem, de forma a construir $o$ embasamento legal para um Código de Ética da grande empresa, nacional ou multinacional, o qual tende a constituir-se em imperativo da ciência universal $;{ }^{22}$ (grifos nossos)

Entretanto, o tratamento dado para o dever de lealdade de controladores e administradores é manifestamente distinto. Alfredo Lamy Filho, um dos autores da LSA, ao comentar as responsabilidades dos agentes participantes de uma sociedade anônima, afirma o que se segue:

Ao administrador - conselheiro ou diretor - a lei, nos arts. 153 a 158, prescreve normas de conduta e define responsabilidades coincidentes, em muitos casos, com as que regulam a atuação do controlador, mas necessariamente mais amplas, por isso que a eles incumbe, de direito, o exercício do poder empresarial.." 23 (grifos nossos)

A lealdade esperada do acionista controlador é tratada de forma simples e genérica no parágrafo único do art. 116, permanecendo como um

\footnotetext{
${ }^{21}$ Alfredo Lamy Filho também faz referência a este dever de lealdade citando a opinião de Wilson de Campos Batalha: "O acionista controlador tem o dever de lealdade para com os demais integrantes da companhia, quer se trate dos outros acionistas ou dos administradores quer se trate dos empresagos. O preceito vai além e, numa visão institucionalista da sociedade anônima, impõe ao acionista controlador o exercício de seu poder no sentido da comunidade em que atua e não apenas no círculo de pessoas vinculadas à empresa, como auxiliares, administradores e empregados. É do interesse relevante da economia nacional a sobrepairar, no conceito do legislador, sobre os interesses particularistas do acionista controlador ou do grupo de controle." (Apud: BATALHA, Wilson de Campos. Comentários à Lei das S.A., vol. 2, p. 562 in: FILHO, Alfredo Lamy. Temas de S.A. Rio de Janeiro: Renovar, 2007. p. 202.)

${ }^{22}$ Exposição de Motivos n ${ }^{\circ}$ 186, de 24 de junho de 1976, do Ministério da Fazenda. Disponível em 〈http://www.cvm.gov.br/export/sites/cvm/legislacao/leis-decretos/anexos/EM196-Lei6404.pdf> Acesso em: 06 no. 2017.

${ }^{23}$ LAMY FILHO, Alfredo. Temas de S.A. Rio de Janeiro: RENOVAR, 2007, p. 157.
} 
conceito aberto de um comportamento esperado do agente que detém o poder de dirigir de forma global o caminho a ser seguido pela companhia.

Por sua vez, o administrador é aquele responsável pela tomada de decisões negociais, a avaliação do dia-a-dia das atividades da companhia ou do desempenho dos negócios ${ }^{24}$. Por mais que o poder de escolha da maioria da administração esteja nas mãos do acionista controlador, a legislação societária criou a figura dos órgãos de administração justamente para trazer uma profissionalização da administração das companhias.

Aquele administrador que toma decisões baseado única e exclusivamente no interesse daquele que o escolheu está infringindo os seus deveres fiduciários e, portanto, sujeito à responsabilidade por sua atuação ${ }^{25}$.

Justamente por estarem atuando na administração do patrimônio alheio, no caso o da companhia, é que o standard da atuação fiduciária dos administradores é muito maior do que o esperado do acionista controlador. Certamente, os administradores, na maioria das companhias brasileiras, possuem poder inferior ao que teriam na maioria das companhias americanas, mas não se pode esquecer que permanece sendo ele o responsável pela administração direta do dia-a-dia da companhia.

Existe uma razão de ordem prática para a diferenciação entre os deveres de lealdade do administrador e do controlador. Enquanto o primeiro exerce função delegada e, portanto, de confiança, o segundo simplesmente

\footnotetext{
${ }^{24}$ Sobre a necessidade das empresas pela gestão de administradores, afirma Fran Martins: "Como pessoas jurídicas, possuidoras de um patrimônio que se destina, em princípio, a produzir lucros capazes de compensar os que para elas concorreram com capitais, as sociedades anônimas necessitam ser geridas por pessoas aptas para fazê-las realizar, com sucesso, o objeto que limita suas atividades. Essas pessoas são os administradores, escolhidos de acordo com o que dispuser a lei e com atribuições estabelecidas por essa e pelo estatuto, que é a carta magna da sociedade." (MARTINS, Fran. Direito Societário: estudos e pareceres. Rio de Janeiro: Ed. Forense, 1984, p. 107)

${ }^{25}$ Sobre o dever dos administradores de não executarem ordens do controlador que importem em infração aos seu deveres fiduciários: "os administradores não se eximem da responsabilidade pelo descumprimento de seus deveres (art. 158) com a alegação de que observaram deliberação da Assembleia Geral ou ordem do acionista controlador que viola a lei ou o estatuto, e não têm apenas a faculdade, mas o dever, de descumpri-la." (LAMY FILHO, Alfredo. PEDREIRA, José Luiz Bulhões. Direito das Companhias. $2^{\mathrm{a}}$ ed. Rio de Janeiro: Forense, 2017. p. 596)
} 
adquiriu a sua posição por possuir direitos de sócio suficientes para se tornar titular dos direitos e responsabilidades advindos da posição de controlador.

\section{A despeito das hipóteses em que o acionista controlador também} exerce função administrativa na companhia, a tendência das maiores empresas é justamente pela profissionalização administrativa. Neste sentido:

Em artigo publicado quando da elaboração da Lei, os autores do anteprojeto assim se expressaram (José Luiz Bulhões Pedreira; Alfredo Lamy Filho, 1996, v.I, p. 195-196): “À proporção que cresce a empresa, e sua administração se torna mais complexa, o controlador perde a capacidade de administrá-la. Se, a princípio, podia tomar todas as decisões, (...) a pouco foi sentindo a necessidade de mobilizar especialistas em cada uma das técnicas utilizadas pela empresa e sobretudo, de buscar o administrador profissional - capaz de organizar ou reorganizar os fatores de produção, em busca da otimização dos resultados. Não o fez nem o faz por munificência, mas obrigado, em regime de competição, a "melhorar e crescer" para sobreviver. Essa evolução - tão conhecida e repetida entre os estudiosos - é que fez ascender ao primeiro plano do status social o administrador, numa evolução que cumpre acelerar. Entre o empregado antigo - acessório da máquina, de que o capitalista era dono - e o administrador profissional da grande empresa, a importância dobrou-se em favor da equipe humana, sem a qual não funciona a máquina. $\mathrm{O}$ administrador tem, por tudo, um lugar, cada vez mais importante na grande, e mesmo na média ou pequena empresas. Na empresa moderna o poder do acionista controlador perdeu, por isso, a sua discricionariedade, limitado, que está, pelo imperativo técnico do administrador profissional. ${ }^{26}$

Para os administradores, existe um claro custo de agência ${ }^{27}$ entre a sua atuação e o interesse dos acionistas, daí a necessidade do estabelecimento de uma relação de fidúcia entre este administrador e a companhia. A intenção da Lei em limitar este conflito de agência é abordada pela doutrina especializada:

A finalidade básica dessa Seção da LSA [Deveres e Responsabilidades dos Administradores] é a de impedir que os administradores anteponham seus interesses pessoais aos interesses da companhia e da universalidade de seus acionistas, ou que sejam negligentes na administração do patrimônio alheio, consagrando-se a teoria, já exposta no capítulo anterior (v. § 274), de que a administração da companhia é composta por órgãos que, como tais, têm

\footnotetext{
${ }^{26}$ LAMY FILHO, Alfredo. PEDREIRA, José Luiz Bulhões. Direito das Companhias. $2^{\mathrm{a}}$ ed. Rio de Janeiro: Forense, 2017, p.610.

${ }^{27}$ Por custo de agência entende-se as perdas e ineficiências resultantes do desalinhamento de interesses entre administradores, que não possuem, a princípio, interesse pessoal na maximização dos lucros da companhia, e acionistas, que buscam sempre a maior margem de lucro.
} 
poderes-funções que lhes são conferidos para que possam exercer e realizar da maneira mais eficiente o objeto social. ${ }^{28}$

Já com relação ao acionista controlador, o seu interesse primordial será sempre a busca do lucro a partir do desenvolvimento daquela atividade econômica, interesse este compartilhado pelos demais acionistas. Logicamente, este interesse deve estar em linha com os interesses da sociedade, preocupação esta que, como visto, foi incorporada à nossa Lei de Sociedade por Ações.

A leitura comparativa dos dispositivos pertinentes aos deveres e responsabilidades dos administradores e dos acionistas controladores já permite inferir a diferença entre os mesmos. Enquanto para o acionista controlador é dispensado um parágrafo para a delimitação de seus deveres (parágrafo único do art. 116), com rápida menção ao dever de lealdade, aos administradores é dedicada quase que uma seção inteira, com cinco artigos tratando de seus deveres fiduciários.

Focando no dever de lealdade, que é o de maior relevância para o estudo aqui realizado, o art. 155 traz uma descrição muito mais completa da lealdade esperada dos administradores, inclusive com a indicação de vedações expressas à atuação dos administradores ${ }^{29}$.

Da análise das vedações constantes do art. 155 pode-se perceber que o tema objeto desta monografia está expressamente descrito no inciso I do artigo, o que nos leva ao próximo item.

\footnotetext{
${ }^{28}$ LAMY FILHO, Alfredo. PEDREIRA, José Luiz Bulhões. Direito das Companhias. $2^{\mathrm{a}}$ ed. Rio de Janeiro: Forense, 2017, p 794.

${ }^{29}$ Art. 155. O administrador deve servir com lealdade à companhia e manter reserva sobre os seus negócios, sendo-lhe vedado:

I - usar, em benefício próprio ou de outrem, com ou sem prejuízo para a companhia, as oportunidades comerciais de que tenha conhecimento em razão do exercício de seu cargo; II - omitir-se no exercício ou proteção de direitos da companhia ou, visando à obtenção de vantagens, para si ou para outrem, deixar de aproveitar oportunidades de negócio de interesse da companhia;

III - adquirir, para revender com lucro, bem ou direito que sabe necessário à companhia, ou que esta tencione adquirir.
} 
Art. 155. O administrador deve servir com lealdade à companhia e manter reserva sobre os seus negócios, sendo-lhe vedado:

I - usar, em benefício próprio ou de outrem, com ou sem prejuízo para a companhia, as oportunidades comerciais de que tenha conhecimento em razão do exercício de seu cargo; $[\ldots]^{30}$ (grifos nossos)

\subsubsection{Escolha legislativa pela não repressão da usurpação de oportunidade comercial por acionistas controladores e a livre iniciativa}

A utilização de oportunidades comerciais por parte de administradores, em benefício próprio ou de terceiros, é expressamente pensada como uma infração ao dever de lealdade do administrador, prevista no art. 155 da LSA.

Por outro lado, ao fazer menção à lealdade dos acionistas controladores e ao abuso do poder de controle, nos arts. 116 e 117 da LSA, o legislador sequer faz menção a essa hipótese.

Ao analisarmos os dois artigos que formam o regime de responsabilidade dos acionistas controladores, percebe-se que o art. 117, que trata da responsabilização dos acionistas controladores por abuso do poder de controle, não traz nenhum elemento novo à regra geral estabelecida no parágrafo único do art. 116, destinando-se apenas a elencar as situações em que o acionista controlador estará infringindo o seu dever genérico de lealdade e atuará em benefício próprio e contra o interesse da companhia.

O rol de hipóteses mencionadas no art. 117 não é exaustivo, uma vez que seria impossível para o legislador prever todas as situações de abuso do poder de controle. Nesta linha:

A enumeração legal é meramente exemplificativa. Qualquer outro ato praticado pelo acionista controlador que viole a norma do parágrafo único do artigo 116 da LSA pode configurar abuso do poder de controle. A enumeração

\footnotetext{
${ }^{30}$ Lei n. 6.404, de 15 de dezembro de 1976. Dispõe sobre as Sociedades por Ações. Disponível em:<http://www.planalto.gov.br/ccivil_03/leis/L6404consol.htm>. Acesso em: 07 nov. 2017.
} 
legal, compreendendo as modalidades mais usuais de abuso, aumenta a eficácia do regime de responsabilidade do acionista controlador, ao eliminar as possíveis dúvidas ou questionamentos sobre o caráter abusivo da ação do controlador nas hipóteses enumeradas na Lei. ${ }^{31}$

Entretanto, a usurpação de oportunidade comercial não é uma daquelas hipóteses que se apresentaram na realidade do Direito societário e não foram pensadas pelo legislador.

Por ter sido expressamente tratada no regime de lealdade esperado dos administradores (art. 155 da LSA), a usurpação de oportunidade comercial foi pensada pelo legislador que, deliberadamente, optou por não incluir tal vedação também aos acionistas controladores.

Ao comentar o regime de responsabilidade do acionista controlador na LSA e a extensão das situações de abuso do poder de controle, Fran Martins defende a possibilidade de usurpação de oportunidade comercial apenas quando o controlador também ocupar cargo na administração da companhia:

\begin{abstract}
A lei relaciona alguns atos apenas exemplificativamente; daí outros, que não os expressamente enumerados, constituírem também atos pelos quais o acionista controlador poderá ser responsabilizado. É o que acontece, como mencionamos, quando administradores de uma sociedade anônima, integrantes do grupo majoritário, criam uma outra sociedade com o mesmo objeto da primeira, localizam a sede dessa sociedade nova na sede da filial da primeira e, sobretudo, procuram afastar clientes desta apondo, nela, cartazes em que se declara que as atividades praticadas pela sociedade primitiva são, agora, realizadas pela sociedade concorrente. ${ }^{32}$
\end{abstract}

Quisera o legislador estender o mesmo dever de lealdade esperado dos administradores aos acionistas controladores, o tratamento teria se dado no mesmo artigo ou teria sido feita referência cruzada entre os dois. Ao contrário, o legislador preferiu delimitar algumas das hipóteses de infração ao dever de lealdade aos administradores e não o fez para controladores.

\footnotetext{
${ }^{31}$ LAMY FILHO, Alfredo. PEDREIRA, José Luiz Bulhões. Direito das Companhias. $2^{\mathrm{a}}$ ed. Rio de Janeiro: Forense, 2017, p. 614.

${ }^{32}$ MARTINS, Fran. Direito Societário: estudos e pareceres. Rio de Janeiro: Ed. Forense, 1984, p. 38.
} 
Existe uma razão sistemática de nosso ordenamento jurídico que explica tal opção legislativa.

Apesar de o mercado de capitais brasileiro apresentar uma concentração de poderes maior nas mãos do acionista controlador, o Direito societário brasileiro é regido pelo princípio constitucional da livre iniciativa.

Logo no art. $1^{\text {o }}$ da Constituição Federal de 1988 está consagrado, como fundamento da República Federativa do Brasil, a livre iniciativa ${ }^{33}$. Ademais, especificamente com relação à ordem econômica, a livre iniciativa aparece novamente como princípio constitucional basilar, como se depreende da leitura do art. 170 da Constituição Federal ${ }^{34}$.

Nas palavras de Caio Mário da Silva Pereira Neto e Paulo Leonardo Casagrande:

O princípio da livre-iniciativa determina que indivíduos e pessoas jurídicas podem desenvolver qualquer atividade econômica, desde que atendidos, quando existentes, requisitos legais específicos (Art. 170, parágrafo único). Estes requisitos legais, por sua vez, não podem ser desarrazoados, a ponto de subtrair completamente a liberdade de iniciativa e tornar inócua a garantia constitucional $^{35}$.

Portanto, qualquer pessoa é livre para a exploração econômica da atividade que estiver disposta a desempenhar, respeitando sempre as regulamentações e regras atinentes a cada um dos setores da economia.

A respeito das sociedades anônimas de capital aberto, não existe na Lei 6.404/76 ou na regulamentação da CVM qualquer restrição a que

\footnotetext{
33 “Art. $1^{\circ}$ A República Federativa do Brasil, formada pela união indissolúvel dos Estados e Municípios e do Distrito Federal, constitui-se em Estado Democrático de Direito e tem como fundamentos: [...] IV - os valores sociais do trabalho e da livre iniciativa;" (Constituição da República Federativa do Brasil de 1988. Disponível em: <http://www.planalto.gov.br/ccivil_03/constituicao/constituicao.htm>. Acesso em: 07 nov. 2017.) 34 “Art. 170. A ordem econômica, fundada na valorização do trabalho humano e na livre iniciativa, tem por fim assegurar a todos existência digna, conforme os ditames da justiça social, observados os seguintes princípios: [...].”(Constituição da República Federativa do Brasil de 1988. Disponível em: <http://www.planalto.gov.br/ccivil_03/constituicao/constituicao.htm>. Acesso em: 07 nov. 2017.)

35 PEREIRA NETO, Caio Mário da Silva. CASAGRANDE, Paulo Leonardo. Direito Concorrencial. São Paulo: Saraiva, 2016. p. 26
} 
determinada pessoa seja acionista controladora de mais de uma companhia aberta com objetos sociais semelhantes.

Muito pelo contrário. Com o crescimento de grupos de investimento cada vez maiores, com a expansão da indústria de private equity ${ }^{36}$, com a popularização dos modelos de investimento baseados em fundos de investimento de participação - FIP ${ }^{37}$, é cada vez comum que uma sociedade ou fundo de investimento seja controlador de diversas empresas do mesmo setor, por vezes até concorrentes entre si.

Diante deste cenário, como é possível defender que um acionista controlador tem o dever de apresentar as oportunidades comerciais de que tem conhecimento às companhias que controla? Como deve proceder um acionista que controle duas companhias abertas do mesmo setor quando a ele for oferecida uma oportunidade que possa ser explorada por ambas?

É por esta razão que as oportunidades oferecidas diretamente ao acionista controlador, e não para as companhias por ele controladas, recaem sob o espectro da liberdade de iniciativa deste controlador para decidir a forma de exploração de tal atividade.

Não está, portanto, em infração ao seu dever de lealdade e, consequentemente, não está atuando com abuso de poder de controle, aquele

\footnotetext{
36 "O fundo de private equity é uma união de recursos financeiros de investidores qualificados administrado por uma organização gestora de investimentos. Segundo Salhman, as organizações de $\mathrm{PE} / \mathrm{VC}$ captam recursos de "indivíduos e instituições para investimento em participação acionária em empresas com alto potencial de crescimento e ao mesmo tempo alto risco" (SILVA, Thiago Mascarenhas de Souza e Silva. O Controle Societário nas Companhias com Investimentos de Fundos de Private Equity Listadas na BM\&FBOVESPA. Trabalho apresentado à Banca Examinadora no Programa de Mestrado da Escola de Direito de São Paulo da Fundação Getúlio Vargas. 2010)

${ }^{37}$ Em publicação oficial da autarquia, a CVM define os FIPs como: "Também conhecido como Fundo de Private Equity, é destinado exclusivamente a investidores qualificados e deve ser constituído sob a forma de condomínio fechado. Seus recursos são destinados à aquisição de ações, debêntures, bônus de subscrição e outros títulos e valores mobiliários conversíveis ou permutáveis em ações de emissão de companhias abertas ou fechadas. Tais aquisições devem propiciar ao fundo, como regra geral, participação no processo decisório da companhia investida, com efetiva influência na definição de sua política estratégica e na sua gestão." (Comissão de Valores Mobiliários. O mercado de valores mobiliários brasileiro. 3. ed. Rio de Janeiro: Comissão de Valores Mobiliários, 2014. pp. 103 e 104).
} 
acionista que decide explorar isoladamente a oportunidade comercial que foi a ele oferecida diretamente.

Conclui-se, a partir deste raciocínio, que não é possível extrair do dever de lealdade imposto aos acionistas controladores a obrigação de apresentação da oportunidade comercial que a ele fora oferecida ou que por ele foi desenvolvida individualmente.

\subsection{Forma de apresentação da oportunidade comercial}

Importante, neste momento, tecer considerações sobre a forma de apresentação das oportunidades comerciais ao acionista controlador.

\section{$\underline{\text { Acionista controlador ocupante de cargo na administração: }}$}

Aquele acionista controlador que ocupa cargo na administração da companhia por ele controlada está sujeito aos mesmos deveres e responsabilidades impostos aos administradores de sociedades anônimas. É o que prescreve o $\$ 3^{\circ}$ do art. 117 da LSA ao afirmar que "o acionista controlador que exerce cargo de administrador ou fiscal tem também os deveres e responsabilidades próprios do cargo”.

Modesto Carvalhosa, ao comentar a posição do acionista controlador ocupante de cargo da administração, também se posiciona pela acumulação dos deveres e responsabilidades inerentes à cada uma das funções:

O controlador poderá ou não ser administrador da companhia. Se este reunir ambas as funções, seus deveres e responsabilidades também serão cumulativos (art. 116,117 e 153$).{ }^{38}$

Não importa, em regra, em que qualidade o acionista/administrador tomou conhecimento da oportunidade comercial que está sendo discutida, ele

\footnotetext{
${ }^{38}$ CARVALHOSA, Modesto. Comentários à lei de sociedades anônimas, $2^{\text {o }}$ volume: artigos 75 a 137. $4^{\text {a }}$ ed. São Paulo: Saraiva, 2008, p. 494.
} 
está proibido de explorar tal oportunidade antes apresentá-la à companhia, nos termos do art. 155, inciso I da LSA.

\section{Como bem salientam Felipe Demori Claudino e Francisco Siemsen}

Bulhões:

Não nos parece crível que se possa distinguir em que "qualidade" o acionista/administrador teve notícia da oportunidade. Impossível dissociar as suas funções quando exercidas pela mesma pessoa. ${ }^{39} 40$

Assim, é de conclusão apressada que, independentemente do meio com o qual tenha tido conhecimento daquela oportunidade comercial, aquele acionista controlador que ocupe cargo na administração da companhia está sujeito à responsabilização por usurpação de oportunidade comercial caso utilize individualmente tal oportunidade, com ou sem prejuízo para a companhia.

Tal vedação advém de seu dever de lealdade enquanto administrador daquela companhia, e não em razão do regime de responsabilidade a ele imposto na função de acionista controlador da companhia.

Entretanto, há situações em que a própria oportunidade será apresentada a um controlador em razão da posição por ele ocupada, independentemente da acumulação de cargos na administração da

\footnotetext{
${ }^{39}$ CLAUDINO, Felipe Demori. BULHÕES, Francisco Simsen. A usurpação de oportunidade comercial pelo acionista controlador: uma abordagem prática. In: HANSZMANN, Felipe (Org.). Atualidades em Direito Societário e Mercado de Capitais $1^{\text {a }}$ ed. Rio de Janeiro: Lumen Juris, 2016. p. 106

${ }^{40}$ Para chegar a esta conclusão os autores fazem referência a Luiz Antonio de Sampaio Campos, que propõe reflexão para a usurpação de oportunidade por parte do administrador, sem tratar da questão do acionista/administrador: "O administrador que toma conhecimento de uma oportunidade de negócio da companhia estará, portanto, obrigado a persegui-la, mesmo que não tenha tomado conhecimento em razão de seu cargo ou no seu exercício. A LSA, acertadamente, traz implícito o conceito de que a função do administrador é indissociável e incindível, e bem assim seus deveres específicos, de tal modo que o administrador, por estar fora do expediente ou do recinto de trabalho, não se despe de sua função ou se demite de seus deveres, retomando-o apenas quando volta a trabalhar. É um fardo permanente que está sujeito o administrador, ressalvadas, evidentemente, as hipóteses em que é imposto o sigilo e que, portanto, o conhecimento da oportunidade não lhe permite a perseguição". (CAMPOS, Luiz Antônio de Sampaio. Conselho de Administração e Diretoria. In: LAMY FILHO, Alfredo. PEDREIRA, José Luiz Bulhões (coords.). Direito das Companhias. Rio de Janeiro: Forense, 2009, pp. 1136 e 1137).
} 
companhia. Analisaremos um desses exemplos no Caso AMBEV, julgado pela CVM em 16 de dezembro de 2017 e inserido no Capítulo 3 abaixo.

Certamente, a identificação da origem de uma informação é extremamente difícil, haja vista os esforços empreendidos por órgãos reguladores ao redor do mundo na punição do ilícito de insider trading, por exemplo. Portanto, identificar em que qualidade o acionista controlador tomou conhecimento ou teve a ele oferecida determinada oportunidade pode ser, no mundo real, prova impossível.

Considerando este cenário, a utilização dos mecanismos de presunções parece ser a melhor saída para a solução do problema.

Por acumular os deveres e responsabilidades de ambos os cargos, o acionista controlador que ocupa cargo na administração está sujeito à presunção relativa de usurpação de oportunidade comercial caso utilize, diretamente, oportunidade que está inserida na atividade desenvolvida pela companhia.

No entanto, como toda presunção relativa, esta também admite prova em contrário, cabendo ao acionista controlador comprovar que a oportunidade foi oferecida a ele enquanto acionista controlador, e não como administrador da companhia. A quebra desta presunção relativa pode acontecer, por exemplo, caso seja demonstrado que o negócio foi concebido para ser desenvolvido apenas pelo acionista controlador, como se verá nos dois itens abaixo.

Caso não fique comprovado que o negócio foi a ele oferecido única e exclusivamente na qualidade de acionista controlador, estará o acionista sujeito à responsabilização por usurpação de oportunidade comercial em razão do dever de lealdade a ele imposto como administrador da companhia, nos termos do inciso I do art. 155 da LSA. 
Acionista controlador que não ocupa cargo na administração e desenvolve oportunidade comercial:

Existem situações em que o próprio acionista controlador será o responsável pelo desenvolvimento de oportunidade que pode ser explorada pela companhia aberta que controla.

Esta hipótese é comum, por exemplo, em empresas do ramo tecnológico, destinadas à produção de softwares, em que o acionista controlador continua sendo o acionista fundador da empresa e a pessoa que desenvolveu o produto inicial por ela explorado.

É possível que este mesmo acionista controlador - que, hipoteticamente, não exerce função na administração da companhia desenvolva novo software que poderia utilizar-se da infraestrutura da companhia para ser produzido. O acionista controlador resolve, entretanto, explorar tal atividade por meio de uma nova empresa por ele constituída fora do âmbito da companhia aberta.

A situação descrita é, portanto, de oportunidade comercial desenvolvida pelo próprio acionista controlador e, consequentemente, a ele pertencente. Neste caso, não há de se falar em usurpação de oportunidade comercial da companhia aberta, uma vez que a oportunidade foi desenvolvida pelo acionista controlador e nunca pertenceu àquela companhia.

Não estará, este acionista, em infração aos seus deveres enquanto controlador da companhia aberta, uma vez que ele não terá utilizado o seu poder para impedir que a companhia realize o seu objeto e cumpra a sua função social, mas única e exclusivamente, utilizado a sua liberdade de iniciativa para explorar a oportunidade por ele mesmo criada da forma que achar mais conveniente.

Também não há de se falar em infração ao dever de lealdade esperado dos acionistas controladores uma vez que, como foi visto anteriormente, o legislador deliberadamente não incluiu a utilização de oportunidades 
comerciais como situação vedada aos acionistas controladores, ao passo que o fez para os administradores.

\section{A escolha da contraparte:}

Por fim, é possível identificar uma última situação que pode se apresentar no mundo real: a escolha da parte que oferece a oportunidade comercial ao acionista controlador.

Sabe-se que, em muitos ramos comerciais, a escolha de uma parceria para desenvolvimento de determinado negócio é fundada na confiança e reputação dos agentes participantes no mercado.

Não é incomum, portanto, que um agente que possui oportunidade inovadora em suas mãos, e que começa a procurar parceiros ou clientes para oferecer o novo negócio, esteja disposto apenas a aceitar parceiros com os quais possua relação antiga de confiança ou que possuam nome reconhecido e respeitado no mercado.

Deve-se considerar, portanto, que em determinadas situações o acionista controlador será abordado por um agente do mercado para desenvolvimento de uma oportunidade comercial, mas este agente estipulará, como condição, que apenas o acionista controlador participe do negócio, excluindo a companhia por ele controlada que, por diversas razões, pode não se mostrar eficiente para a exploração daquela atividade.

Dentre tais razões pode-se mencionar: (i) a situação financeira da companhia pode não garantir a segurança necessária para aquele agente que oferece a oportunidade; (ii) a estrutura de governança de uma companhia aberta pode não condizer com a eficiência e celeridade necessárias para a atividade. Enfim, diversos fatores comerciais podem contribuir para que a contraparte escolha manter apenas o acionista controlador como seu parceiro no desenvolvimento da atividade. 
Por outro lado, caso o agente ofertante da oportunidade comercial queira desenvolvê-la em parceria com a companhia aberta, sociedade consolidada e respeitada no mercado em que pretende atuar, este agente certamente procurará os administradores desta companhia ou, se procurar o acionista controlador, manifestará sua exigência de que a oportunidade seja explorada dentro do âmbito da companhia aberta.

Percebe-se que em determinadas situações, os anseios comerciais daquele que oferece a oportunidade comercial ao acionista controlador podem ser fundamentais para que este decida oferecer ou não a oportunidade à companhia da qual detém o controle.

Em nenhuma das hipóteses, seja apresentando ou não a oportunidade à companhia controlada, o acionista controlador estará sujeito à responsabilização por usurpação de oportunidade comercial, pelo mesmo motivo exposto acima: não é possível extrair do dever de lealdade imposto aos acionistas controladores a obrigação de apresentação da oportunidade à companhia.

As seguintes afirmações resumem as hipóteses apresentadas acima: apenas haverá usurpação de oportunidade comercial quando a oportunidade efetivamente for da companhia. Oportunidades apresentadas apenas aos acionistas controladores pertencem a eles e, portanto, não são passíveis de responsabilização por usurpação. 


\section{CAPÍTULO 2 - CORPORATE OPPORTUNITY DOCTRINE}

A corporate opportunity doctrine nada mais é do que o desenvolvimento jurisprudencial de common law de uma limitação à liberdade de determinados agentes na exploração direta de oportunidades comerciais, sem o prévio oferecimento prévio à companhia com a qual possuem relação fiduciária ${ }^{41}$.

Como será demonstrado nos próximos capítulos desta monografia, o estudo da corporate opportunity doctrine é fundamental para se entender a posição da corrente majoritária brasileira - e de alguns casos julgados pela CVM - a respeito da exploração de oportunidade comercial pelo acionista controlador.

Para os seguidores desta corrente, os acionistas controladores exercem, no Brasil, influência semelhante na condução dos negócios sociais desempenhada por um administrador das corporations americanas. Partindo deste pressuposto, seria razoável utilizar-se de inspiração na corporate opoortunity doctrine americana para analisar a suposta usurpação de oportunidade comercial de acionistas controladores no Brasil.

\subsection{Desenvolvimento da Corporate Opportunity Doctrine - a evolução dos testes de verificação}

$\mathrm{O}$ desenvolvimento da corporate opportunity doctrine remonta ao início do século $\mathrm{XX}$, quando a jurisprudência americana enfrentou os primeiros casos de quebra do dever de lealdade de administradores na utilização de oportunidades comerciais.

\footnotetext{
${ }^{41}$ TALLEY, Eric e HASHMALL, Mira. The corporate opportunity doctrine. U.S.C. Institute for Corporate Counsel: Los Angeles, 2001. p. 1: "The corporate opportunity doctrine ("COD”) is a common law doctrine that limits a corporate fiduciary's ability to pursue new business prospects individually without first offering them to the corporation." Em tradução livre: "A corporate opportunity doctrine ("COD") é uma doutrina da common law que limita a capacidade de um acionista com dever fiduciário de buscar novas perspectivas de negócios individualmente sem primeiro oferecê-las à companhia.”
} 
Ao longo do tempo, a jurisprudência americana foi desenvolvendo testes de verificação das hipóteses de usurpação de oportunidade comercial, garantindo maior previsibilidade e orientação aos agentes de mercado envolvidos na administração das corporations americanas. Serão analisados cada um dos testes propostos pelos precedentes americanos.

\subsubsection{Interesse e expectativa}

Talvez a forma mais antiga de análise da ocorrência de usurpação de oportunidade comercial por administradores passe pela aferição dos conceitos de interesse e expectativa ${ }^{42}$.

$\mathrm{Na}$ ponta do interesse, serão consideradas oportunidades comerciais aquelas que se refiram a projetos com os quais a companhia já tenha um direito contratual vigente ${ }^{43}$.

Com relação à expectativa, será considerada oportunidade aquela que, embora ainda não garantida contratualmente, tenha grande probabilidade de se tornar um direito contratual, considerando os direitos já existentes de titularidade da companhia. A respeito do elemento expectativa, a doutrina americana cita como exemplo as relações de continuidade com fornecedores em que, embora ainda não haja aditivo contratual expandindo a relação para determinado período, a companhia possui razoável expectativa da

\footnotetext{
${ }^{42}$ TALLEY, Eric e HASHMALL, Mira. The corporate opportunity doctrine. U.S.C. Institute for Corporate Counsel: Los Angeles, 2001. p. 4: "The longest-standing characterization test for determining whether new business prospects are corporate opportunities turns on whether the corporation has an active commercial interest or expectancy in such opportunities.". Em tradução livre: "O teste de caracterização mais antigo para determinar se as novas oportunidades de negócios são consideradas oportunidades comerciais se baseia no interesse ou na expectativa comercial da empresa em explorar tais oportunidades."

43 TALLEY, Eric e HASHMALL, Mira. The corporate opportunity doctrine. U.S.C. Institute for Corporate Counsel: Los Angeles, 2001. p. 4: "The "interest" component of this approach usually refers to projects over which the corporation has an existing contractual right.". Em tradução livre: "O componente "interesse" desta abordagem geralmente se refere a projetos sobre os quais a empresa possui um direito contratual existente."
} 
confirmação da extensão a partir da relação duradoura com aquela contraparte ${ }^{44}$.

Apesar de garantir certa previsibilidade na aferição de uma oportunidade comercial, o teste foi considerando extremamente limitador por abranger apenas as atividades já desenvolvidas pela companhia, deixando de fora os projetos futuros pretendidos, mas ainda não iniciados. ${ }^{45}$

Como se verá adiante, os testes desenvolvidos em seguida apresentaram abordagem muito mais ampla, mas desta vez receberam críticas pelo seu subjetivismo e falta de previsibilidade.

\subsubsection{Line of Business}

A segunda fase da corporate opportunity doctrine tem como marco inicial o julgamento do famoso caso Guth vs. Loft pela Suprema Corte de

\footnotetext{
${ }^{44}$ TALLEY, Eric e HASHMALL, Mira. The corporate opportunity doctrine. U.S.C. Institute for Corporate Counsel: Los Angeles, 2001. pp. 4 e 5: "The "expectancy" component includes projects that, while not already secured through an express contract, are likely, given current rights, to ma ture into contractual rights at some future date. Of particular relevance here are so-called "relational" contracts between the corporation and repeat trading partners, in which periodic extensions are not expressly provided for but can be reasonably assumed.". Em tradução livre: "O componente "expectativa" inclui projetos que, embora ainda não tenham sido garantidos através de um contrato expresso, são prováveis, visto os direitos já adquiridos, para garantir direitos contratuais em alguma data futura. De particular relevância aqui são os chamados contratos "relacionais" entre a corporação e os parceiros comerciais usuais, nos quais as extensões periódicas não estão expressamente previstas, mas podem ser razoavelmente assumidas."

45 TALLEY, Eric e HASHMALL, Mira. The corporate opportunity doctrine. U.S.C. Institute for Corporate Counsel: Los Angeles, 2001. pp. 4 e 5: "Notably, the interest-or-expectancy test ultimately defines a corporate opportunity largely by reference to current (rather than prospective) activities of the corporation. As such, the test provides a relatively predictable boundary. Indeed, the narrow reach of the test effectively limits it to those projects about which the firm (by virtue of its existing contractual rights) already has actual or reasonable knowledge. Despite its administrative convenience, however, the test has been criticized as under-inclusive because it reaches only those projects over which the corporation's proprietary claim is relatively mature.". Em tradução livre: "Particularmente, o teste de intersse ou expectativa, em última instância, define uma oportunidade corporativa em grande parte por referência a atividades atuais (e não prospectivas) da companhia. Como tal, o teste fornece uma limitação relativamente previsível. De fato, o alcance estreito do teste efetivamente o limita-se aos projetos sobre os quais a empresa (em virtude de seus direitos contratuais existentes) já possui conhecimento real ou razoável. Apesar de sua conveniência administrativa, no entanto, o teste foi criticado como sendo sub-inclusivo, uma vez que abrange apenas os projetos sobre os quais a reivindicação da companhia de propriedade já é relativamente consolidada."
} 
Delaware, até hoje considerado um dos principais precedentes da common law na análise do dever de lealdade dos administradores ${ }^{46}$.

O caso Guth vs. Loft decidiu a disputa entre Charles G. Guth e a companhia anteriormente dirigida por ele, Loft Inc., acabando por determinar o futuro de uma das mais famosas companhias americanas, a Pepsi-Cola.

Após um início promissor, ainda no século XIX, a Pepsi-Cola viu suas taxas de lucro caírem vertiginosamente com o aumento do preço da mão-deobra e do açúcar ${ }^{47}$. Seu sócio fundador, Caleb D. Bradham, procurou diversas formas para reerguer seu negócio (incluindo a tentativa de venda da empresa para seu maior competidor, a Coca-Cola), mas acabou vendo sua empresa tornar-se insolvente em 1922.

Nos anos seguintes, alguns investidores tentaram reerguer a PepsiCola, mas foi Guth quem conseguiu livrar a companhia da falência. Guth era administrador da Loft Inc. que, em conjunto com suas controladas, geriam mais de 200 lojas de doce nos Estados Unidos. À época, estas lojas comercializavam os refrigerantes Coca-Cola e, portanto, tinham a gigante americana como um dos seus principais fornecedores.

O interesse de Guth pela Pepsi-Cola surgiu quando a Coca-Cola rejeitou uma proposta de redução do preço do refrigerante fornecido às lojas administradas pela Loft. Inconformado com a situação, Guth procurou os antigos controladores da Pepsi, celebrando acordo para aquisição da marca e a fórmula do produto desenvolvido pela companhia de refrigerantes. Com o controle do negócio em suas mãos, Guth substituiu toda a venda de CocaCola das suas lojas pelos produtos Pepsi.

\footnotetext{
${ }^{46}$ Holger Spamann, ao comentar o caso, afirma que Guth vs. Loft "is the mother of all Delaware duty of loyalty cases" Em tradução livre: "é a base para todos os casos envolvendo dever de lealdade em Delaware". SPAMANN, Holger. Guth v. Loft (Del. 1939) [Pepsi]. Disponível em: https://h2o.law.harvard.edu/collages/4308. Acesso em 07 nov. 2017.

${ }^{47}$ Jennifer Ying em Guth v. Loft: The Story of Pepsi-Cola and the Corporate Opportunity Doctrine. Maio, 2009. Disponível em: <https://papers.ssrn.com/sol3/papers.cfm?abstract_id=1414478> Acesso em: 07 nov. 2017.
} 
Entretanto, Guth não estava em condições financeiras para alavancar um negócio como o da Pepsi, e enxergou na Loft, empresa por ele administrada, uma oportunidade para desempenhar tal função. Entre os anos de 1931 e 1935 Guth controlou inteiramente a administração da Loft $^{48}$, fazendo com que toda a estrutura, material humano, e recursos da empresa fossem destinados ao desenvolvimento da atividade da Pepsi-Cola. Na consecução destes negócios, as dívidas da Pepsi e do próprio Guth para com a Loft cresciam exponencialmente.

Quando os acionistas da Loft descobriram que, na verdade, Guth havia realizado o acordo para compra da Pepsi em seu próprio nome e que havia utilizado os recursos da Loft durante anos para benefício próprio, retiraram Guth da administração da Companhia e ordenaram a transferência das ações da Pepsi para a Loft. A discussão foi levada ao Judiciário americano até chegar à Suprema Corte de Delaware, que decidiu que a oportunidade de aquisição da marca e fórmula pertenciam à Loft, e que Guth não tinha o direito de apropriar-se daquela oportunidade ${ }^{49}$.

\footnotetext{
${ }^{48}$ A respeito do controle de Guth na administração da Loft, a Suprema Corte de Delaware assim se manifestou: "Guth was not merely a director and the president of Loft. He was its master. It is admitted that Guth manifested some of the qualities of a dictator. The directors were selected by him. Some of them held salaried positions in the company. All of them held their positions at his favor. Whether they were supine merely, or for sufficient reasons entirely subservient to Guth, it is not profitable to inquire. It is sufficient to say that they either wilfully or negligently allowed Guth absolute freedom of action in the management of Loft's activities, and theirs is an unenviable position whether testifying for or against the appellants. " Em tradução livre: "Guth não era apenas o diretor e o presidente da Loft. Ele era seu mestre. Admite-se que Guth manifestou algumas das qualidades de um ditador. Os diretores foram selecionados por ele. Alguns deles ocuparam posições assalariadas na companhia. Todos eles mantiveram suas posições a seu favor. Se eles eram meramente indolentes, ou por razões suficientes inteiramente subordinadas a Guth, não é útil investigar. Basta dizer que autorizaram intencionalmente ou negligentemente a liberdade absoluta de ação de Guth na gestão das atividades de Loft, e a posição deles é não é invejável, quer testemunhe a favor ou contra os apelantes". Suprema Corte de Delaware, 5 A.2d 503 Guth vs. Loft, Chief Justice Layton, 11 abr. 1939. Disponível em <https://h2o.law.harvard.edu/collages/4308>. Acesso em 07 nov. 2017.

${ }^{49}$ Segundo o dispositivo da decisão da Suprema Corte de Delaware "Upon a consideration of all the facts and circumstances as disclosed we are convinced that the opportunity to acquire the PepsiCola trademark and formula, goodwill and business belonged to the complainant, and that Guth, as its President, had no right to appropriate the opportunity to himself." Em tradução livre: "Após a consideração de todos os fatos e circunstâncias divulgados, estamos convencidos de que a oportunidade de adquirir a marca e fórmula de Pepsi-Cola, a boa-fé e os negócios pertenciam ao requerente, e que Guth, como seu presidente, não tinha o direito de se apropriar da oportunidade para ele mesmo". Suprema Corte de Delaware, 5 A.2d 503 Guth vs. Loft, Chief Justice Layton, 11 abr. 1939. Disponível em <https://h2o.law.harvard.edu/collages/4308>. Acesso em 07 nov. 2017.
} 
Ao proferir a sua decisão, a Suprema Corte de Delaware entendeu que os administradores desempenham papel fiduciário que demanda lealdade com relação à companhia, não sendo a eles permitido usar a sua posição de confiança para a satisfação de interesses pessoais:

Corporate officers and directors are not permitted to use their position of trust and confidence to further their private interests. While technically not trustees, they stand in a fiduciary relation to the corporation and its stockholders. A public policy, existing through the years, and derived from a profound knowledge of human characteristics and motives, has established a rule that demands of a corporate officer or director, peremptorily and inexorably, the most scrupulous observance of his duty, not only affirmatively to protect the interests of the corporation committed to his charge, but also to refrain from doing anything that would work injury to the corporation, or to deprive it of profit or advantage which his skill and ability might properly bring to it, or to enable it to make in the reasonable and lawful exercise of its powers. The rule that requires an undivided and unselfish loyalty to the corporation demands that there shall be no conflict between duty and self-interest. The occasions for the determination of honesty, good faith and loyal conduct are many and varied, and no hard and fast rule can be formulated. The standard of loyalty is measured by no fixed scale. ${ }^{50}$ (grifos nossos)

Para a Suprema Corte de Delaware, a oportunidade será da companhia quando (i) a companhia for financeiramente capaz de explorá-la, (ii) for, por sua natureza, inserida na linha de negócios desenvolvida pela companhia; e (iii) quando a companhia tiver interesse ou legítima expectativa na sua exploração ${ }^{51}$. Nestas situações o interesse particular do administrador será

\footnotetext{
${ }^{50} \mathrm{Em}$ tradução livre: "Conselheiros e diretores não estão autorizados a usar sua posição de confiança para promover seus interesses privados. Embora tecnicamente não sejam administradores, eles mantêm uma relação fiduciária com a corporação e seus acionistas. Uma política pública, existente ao longo dos anos, e derivada de um profundo conhecimento de características e motivos humanos, estabeleceu uma regra que exige de um diretor ou conselheiro, peremptória e inexoravelmente, a observância mais escrupulosa de seu dever, não apenas de proteger os interesses da companhia comprometidos com a sua responsabilidade, mas também abster-se de fazer qualquer coisa que possa prejudicar a companhia, ou privá-la de lucro ou vantagem que sua habilidade e competência possam adequadamente trazer para a companhia e permitir-lhe que fazer no exercício razoável e lícito dos seus poderes. A regra que exige uma lealdade indivisa e desinteressada com a companhia exige que não haja conflito entre dever e interesse próprio. As ocasiões para a determinação da honestidade, boa fé e conduta leal são muitas e variadas, e nenhuma regra dura e rápida pode ser formulada. O padrão de lealdade é medido sem escala fixa.". Suprema Corte de Delaware, 5 A.2d 503 Guth vs. Loft, Chief Justice Layton, 11 abr. 1939. Disponível em <https://h2o.law.harvard.edu/collages/4308>. Acesso em 07 nov. 2017.

${ }^{51} \mathrm{~A}$ respeito dos standards mencionados, a Suprema Corte de Delaware também deixou clara a caracterização de cada um deles no caso Guth vs. Loft ao concluir que a atuação de Guth não apenas o colocou em posição de competição no setor de uma matéria-prima essencial aos negócios da Loft como utilizou os recursos desta última para o desenvolvimento das atividades da Pepsi-Cola: "The
} 
conflitante com o da companhia, razão pela qual ele deverá abster-se de explorar a atividade diretamente. ${ }^{52}$

Os testes de verificação apresentados pelo caso Guth vs. Loft ficaram conhecidos como os testes da Line of Business no desenvolvimento da corporate opportunity doctrine.

Faz-se necessário, no entanto, alertar que a decisão do Caso Guth vs. Loft faz algumas ressalvas à caracterização de usurpação de oportunidades comerciais, reconhecendo que quando a oportunidade for oferecida ao administrador na posição de pessoa comum, e não de administrador, e quando a oportunidade, por sua natureza, não for do interesse ou expectativa da companhia por ele administrada, não haverá caracterização da quebra de seu dever de lealdade, estando o administrador livre para explorá-la individualmente ${ }^{53}$.

\footnotetext{
facts and circumstances demonstrate that Guth's appropriation of the Pepsi-Cola opportunity to himself placed him in a competitive position with Loft with respect to a commodity essential to it, thereby rendering his personal interests incompatible with the superior interests of his corporation; and this situation was accomplished, not openly and with his own resources, but secretly and with the money and facilities of the corporation which was committed to his protection." Em tradução livre: "Os fatos e circunstâncias demonstram que a apropriação de Guth da oportunidade da PepsiCola para ele próprio colocou-o em uma posição competitiva com Loft em relação a uma mercadoria essencial para ela, tornando seus interesses pessoais incompatíveis com os interesses superiores de sua companhia; e esta situação foi realizada, não abertamente e com seus próprios recursos, mas secretamente e com o dinheiro e as recursos da companhia que estava sob sua proteção"

${ }^{52}$ Trecho da Decisão da Suprema Corte de Delaware: "On the other hand, it is equally true that, if there is presented to a corporate officer or director a business opportunity which the corporation is financially able to undertake, is, from its nature, in the line of the corporation's business and is of practical advantage to it, is one in which the corporation has an interest or a reasonable expectancy, and, by embracing the opportunity, the self-interest of the officer or director will be brought into conflict with that of his corporation, the law will not permit him to seize the opportunity for himself. And, if, in such circumstances, the interests of the corporation are betrayed, the corporation may elect to claim all of the benefits of the transaction for itself, and the law will impress a trust in favor of the corporation upon the property, interests and profits so acquired. "Em tradução livre: "Por outro lado, é igualmente verdade que, se for apresentado a um diretor ou conselheiro uma oportunidade comercial que a empresa seja financeiramente capaz de realizar, e esteja, pela sua natureza, na linha do negócio da empresa, e sendo vantajoso para companhia explorar aquela atividade, é considerado que a companhia possui interesse ou expectativa razoável para explorar a atividade e, ao abraçar a oportunidade, o interesse próprio do diretor ou gerente entrará em conflito com o de sua companhia e a lei não permitirá que ele aproveite a oportunidade para si mesmo. E, se, em tais circunstâncias, os interesses da companhia forem traídos, a empresa pode optar por reivindicar todos os benefícios da transação para si mesma, e a lei dará à companhia a propriedade, interesses e lucros assim adquiridos." Disponível em 〈https://h2o.law.harvard.edu/collages/4308> Acesso em: 07 nov. 2017.

${ }^{53}$ Trecho da Decisão da Suprema Corte de Delaware: "It is true that when a business opportunity comes to a corporate officer or director in his individual capacity rather than in his official capacity,
} 
Alguns autores chegam a incorporar este teste de verificação para a análise da usurpação de oportunidades comerciais, mas fazem a ressalva de que o teste do Line of Business não deve ser entendido como abrangente de todo o rol de atividades elencadas no que conhecemos como objeto social de uma companhia ${ }^{54}$.

Acontece que a prática societária brasileira acabou por criar descrições muito amplas no objeto social de companhias, fazendo com que a companhia desenvolva, efetivamente, apenas algumas das atividades ali elencadas. É por isso que a doutrina sugere que a aplicação do teste de Line of Business considere como oportunidades pertencentes à companhia não as matérias elencadas em seu estatuto social, mas as atividades efetivamente desenvolvidas pela companhia. Nesta linha:

A primeira dessas ressalvas se refere à análise do objeto social da companhia. Como é sabido, muitas companhias possuem objeto social que não alcança o espectro mais largo de sua linha de negócios. Por outro lado, outras companhias inserem o máximo de atividades possível, mesmo que efetivamente não estejam

and the opportunity is one which, because of the nature of the enterprise, is not essential to his corporation, and is one in which it has no interest or expectancy, the officer or director is entitled to treat the opportunity as his own, and the corporation has no interest in it, if, of course, the officer or director has not wrongfully embarked the [5 A.2d 511] corporation's resources therein. Colorado \& Utah Coal Co. v. Harris et al., 97 Colo. 309, 49 P.2d 429; Lagarde v. Anniston Lime \& Stone Co., 126 Ala. 496, 28 So. 199; Pioneer Oil \& Gas Co. v. Anderson, 168 Miss. 334, 151 So. 161; Sandy River R. Co. v. Stubbs, 77 Me. 594, 2 A. 9; Lancaster Loose Leaf Tobacco Co. v. Robinson, $199 \mathrm{Ky} .313$, 250 S.W. 997. But, in all of these cases, except, perhaps, in one, there was no infidelity on the part of the corporate officer sought to be charged.". Em tradução livre: "É verdade que, quando uma oportunidade comercial chega a um conselheiro ou diretor em sua capacidade individual e não na sua capacidade oficial, e a oportunidade é uma que, por causa da natureza da empresa, não é essencial para companhia e é uma oportunidade em que não há interesse ou expectativa, o conselheiro ou o diretor tem o direito de tratar a oportunidade como sua, e a companhia não terá interesse nela, se, obviamente, o conselheiro ou o diretor não utilizarem indevidamente [5 A .2d 511] recursos da companhia. Colorado \& Utah Coal Co. v. Harris et al., 97 Colo. 309, 49 P.2d 429; Lagarde v. Anniston Lime \& Stone Co., 126 Ala. 496, 28 So. 199; Pioneer Oil \& Gas Co. c. Anderson, 168 Miss. 334, 151 So. 161; Sandy River R. Co. v. Stubbs, 77 Me. 594, 2 A. 9; Lancaster Loose Leaf Tobacco Co. contra Robinson, 199 Ky. 313, 250 S.W. 997. Mas, em todos esses casos, exceto, talvez, em um, não houve infidelidade por parte do administrador para que fosse cobrado." Disponível em 〈https://h2o.law.harvard.edu/collages/4308> Acesso em: 07 nov. 2017

${ }^{54} \mathrm{O}$ art. $2^{\circ}, \S 2^{\circ}$ de nossa Lei $6.404 / 76$ possui a seguinte redação:

“Art. $2^{\circ}$ Pode ser objeto da companhia qualquer empresa de fim lucrativo, não contrário à lei, à ordem pública e aos bons costumes. [...]

$\S$ ' $2^{\circ}$ O estatuto social definirá o objeto de modo preciso e completo." Disponível em: <http://www.planalto.gov.br/ccivil_03/leis/L6404consol.htm> Acesso em: 07 nov. 2017. 
sendo por ela exercidas, apenas com o fito de assim não gerar direito de recesso por modificação de objeto social ou desenquadramento fiscal ${ }^{55}$.

Dessa forma, o texto estático estatutário pode não acompanhar a dinâmica dos negócios das companhias. Portanto, deve-se sempre fazer uma análise mais subjetiva da linha de negócios efetivamente desenvolvida pela companhia, constante de sua estratégia dentro daquilo que efetivamente se espera nas suas atividades. ${ }^{56}$

\subsubsection{Fairness Test}

O terceiro teste desenvolvido pela jurisprudência norte-americana utiliza o conceito de justiça na determinação da existência de oportunidades comerciais pertencentes à companhia. Seguindo esta linha de raciocínio, seria necessário aplicar padrões éticos de justiça aos fatos do caso para determinar se, à época da utilização da oportunidade pelo administrador, tal oportunidade pertencia à companhia por ele administrada ${ }^{57}$.

A primeira menção ao Fairness Test é feita no caso Durfee v. Durfee \& Canning, Inc., julgado pela Suprema Corte do Estado de Massachusetts no ano de 1947.

Naquele caso, os acionistas da Durfee \& Canning, Inc., companhia destinada à distribuiçãa de produtos derivados do petróleo, ingressaram com ação judicial contra Canning, vice-presidente, administrador e também

\footnotetext{
${ }^{55}$ CAMPOS, Luiz Antônio de Sampaio. Conselho de Administração e Diretoria. In: LAMY FILHO, Alfredo. PEDREIRA, José Luiz Bulhões (coords.). Direito das Companhias. Rio de Janeiro: Forense, 2009. p. 1133.

${ }^{56}$ CLAUDINO, Felipe Demori. BULHÕES, Francisco Simsen. A usurpação de oportunidade comercial pelo acionista controlador: uma abordagem prática. In: HANSZMANN, Felipe (Org.). Atualidades em Direito Societário e Mercado de Capitais $1^{\mathrm{a}}$ ed. Rio de Janeiro: Lumen Juris, 2016, p. 121.

57 "Under the third method, the "fairness test," determination of the existence of a corporate opportunity requires an application of ethical standards of fairness to facts. There is no general rule to cover all situations; the test is applied to the facts and circumstances existing at the time the officer or director appropriated the opportunity". Em tradução livre: "Segundo o terceiro método, o "fairness test", a determinação da existência de uma oportunidade comercial exige uma aplicação de padrões éticos de equidade aos fatos. Não existe uma regra geral para abranger todas as situações; $\mathrm{O}$ teste é aplicado aos fatos e circunstâncias existentes no momento em que o conselheiro ou o diretor se apropriaram da oportunidade." (SLAUGHTER, James C. The Corporate Opportunity Doctrine. Disponível em: $\langle$ http://scholar.smu.edu/cgi/viewcontent.cgi?article=4215\&context=smulr $>$. Acesso em 07 nov. 2017.p. 98).
} 
acionista da companhia, pedindo o ressarcimento da companhia por danos causados por Canning a partir da quebra de seu dever de lealdade.

A Durfee \& Canning, Inc. celebrou diversos acordos para a compra de gasolina com a Pacific Gas Corporation, a preços acima do praticado pelo mercado e muito superiores aos anteriormente pagos pela Pacific Gas Corporation para a mesma quantidade do produto. Apesar de ter realizado as transações como administrador da Durfee \& Canning, Inc., Canning omitiu dos demais administradores da companhia que detinha interesses relevantes na contraparte daqueles negócios, figurando como administrador e acionista também da Pacific Gas Corporation.

Diferentemente dos testes anteriores - que analisavam o legítimo interesse e expectativa da companhia na exploração da oportunidade, ou a inclusão daquela oportunidade na linha de negócios já desenvolvida pela companhia -, a Suprema Corte de Massachusetts entendeu que deve ser analisada a justeza das circunstâncias que levaram à utilização da oportunidade por parte do administrador. A decisão judicial deveria, portanto, se pautar em padrões éticos e justos dentro do conjunto fático para determinar se o administrador poderia ou não se utilizar daquela oportunidade sem desrespeitar seu dever de lealdade para com a companhia. ${ }^{58}$

\footnotetext{
58 "We do not concur in the argument of counsel for the defendant to the effect that the test is whether the corporation has an existing interest or an expectancy thereof in the property involved, being of the opinion that the true basis of the governing doctrine rests fundamentally on the unfairness in the particular circumstances of a director, whose relation to the corporation is fiduciary, "taking advantage of an opportunity [for his personal profit] when the interests of the corporation justly call for protection. This calls for the application of ethical standards of what is fair and equitable [in] particular sets of facts." Em tradução livre: "Não concordamos com o argumento do advogado do réu no sentido de que o teste se baseia em se a corporação tem um interesse existente ou na expectativa na propriedade envolvida, sendo de opinião que a verdadeira base da doutrina reside fundamentalmente na injustiça das circunstâncias particulares de um diretor, cuja relação com a corporação é fiduciária, "aproveitando uma oportunidade [para seu lucro pessoal] quando os interesses da corporação exigem justamente a proteção. Isso exige a aplicação de padrões éticos de O que é justo e equitativo [em] conjuntos particulares de fatos." Trecho extraído da decisão da Suprema Corte de Massachusetts, disponível em <http://masscases.com/cases/sjc/323/323mass187.html. $>$ Acesso em: 07 nov. 2017.
} 
Alguns autores sustentam que a aplicação do Fairness Test por Durfee v. Durfee \& Canning, Inc. ficou limitada às hipóteses de usurpação de oportunidade comercial com posterior tentativa de venda da mesma oportunidade à companhia prejudicada. Isto porque a Suprema Corte de Massachusetts fez expressa distinção entre o caso que estava sendo julgado e Lincoln Stores, Inc. v. Grant, caso em que a oferta posterior da oportunidade não ocorreu.

Apesar de ser citado como um caso limitador da usurpação às hipóteses de revenda da oportunidade à companhia, James C. Slaughter menciona que diversos outros casos não apresentaram tal restrição ${ }^{59}$, sendo Fairness Test desenvolvido em Durfee v. Durfee \& Canning, Inc. aplicável a qualquer das discussões sobre usurpação de oportunidade comercial.

\subsubsection{Método Misto}

A partir dos casos Guth vs. Loft e Durfee v. Durfee \& Canning, Inc., o Line of Business Test e o Fairness Test se tornaram os principais testes de verificação da responsabilidade de administradores por usurpação de oportunidade comercial na jurisprudência americana. Entretanto, ambos os testes sofreram fortes críticas da doutrina, ensejando a criação de um método misto de verificação.

Charles O’Kelley e Robert Thompson afirmam que o Line of Business Test falhava em dois principais pontos. O primeiro em razão da dificuldade em delimitar se determinada atividade está ou não inserida na linha de negócios da companhia. O segundo em razão de Guth vs. Loft possuir como elemento determinante a capacidade financeira da companhia em explorar

\footnotetext{
59 SLAUGHTER, James C. The Corporate Opportunity Doctrine. Disponível em: $<$ http://scholar.smu.edu/cgi/viewcontent.cgi?article=4215\&context=smulr $>$. Acesso em 07 nov. 2017. Na obra, o autor cita os seguintes casos: Presidio Mining Co. v. Overton, 261 Fed. 933 (9th Cir. 1919); Industrial Indem. Co. v. Golden State Co., 117 Colo. App. 2d 519, 256 P.2d 677 (1953); Rosenblum v. Judson Eng'r Corp., 99 N.H. 267, 109 A.2d 558 (1954); Litwin v. Allen, 25 N.Y.S.2d 667 (Sup. Ct. 1940).
} 
aquela oportunidade, o que poderia desincentivar os diretores a resolverem os problemas financeiros da companhia ${ }^{60}$.

Na mesma linha o Fairness Test, diziam O'Kelley e Thompson, também falharia por ser muito amplo e necessitar de intensa análise factual. Neste sentido, o precedente de Durfee v. Durfee \& Canning, Inc. traria pouca ou nenhuma orientação a administradores a respeito de extensão de suas obrigações ${ }^{61}$.

Diante deste cenário, a Suprema Corte de Minnesota decidiu combinar os dois testes, criando uma espécie de método misto em uma "two-step analysis". A inovação foi trazida no caso Miller v. Miller, julgado pela Suprema Corte de Minnesota em 20 de setembro de $1974^{62}$.

O caso Miller $v$. Miller é iniciado por Oscar M. Miller, acionista minoritário da Miller Waste Mills, Inc. que, inconformado com a suposta utilização indevida de oportunidades comerciais por parte de administradores da companhia, ingressa no Judiciário americano pedindo a reparação dos prejuízos à causados à Miller Waste Mills. Segundo o autor da ação, os administradores Rudolph W. Miller e Benjamin A. Miller teriam constituído,

\footnotetext{
${ }^{60}$ The line of business test suffers from some significant weakness. First, the questions whether a particular activity is within a corporation's line of business is conceptually difficult to answer. [...] Second, the Guth test includes as an element the financial ability if the corporation to take advantage of the opportunity. [...] Reliance on financial ability will also act as disincentive to corporate executives to solve corporate financing and other problems." Em tradução livre: "O line of business test sofre de algumas falhas significativas. Em primeiro lugar, a questão de saber se uma determinada atividade está dentro da linha de negócios de uma empresa é conceitualmente difícil de responder. [...] Em segundo lugar, o teste de Guth inclui como elemento a capacidade financeira de a empresa aproveitar a oportunidade. [...] A dependência da capacidade financeira também atuará como desincentivo aos executivos corporativos para resolver o financiamento corporativo e outros problemas." (O'KELLEY, Charles Rogers Taber. THOMPSON, Robert B. Corporations and other business associations: cases and materials. $3^{\text {rd }}$ ed. Apen Law \& Business: New York, 1999. p. 338) ${ }_{61}$ "As with the Guth test, the Durfee test calls for a broad-ranging, intensely factual inquiry. The Durfee test suffers even more than the Guth test from a leck of principled content. It provides little or no practical guidance to the corporate officer or director seeking to measure her obligations." Em tradução livre: "Tal como acontece com o teste de Guth, o teste de Durfee requer um inquérito abrangente e factual. O teste de Durfee sofre ainda mais do que o teste de Guth de um leque de princípios. Ele fornece pouca ou nenhuma orientação prática para o conselheiro ou diretor que procura medir suas obrigações." (O'KELLEY, Charles Rogers Taber. THOMPSON, Robert B. Corporations and other business associations: cases and materials. $3^{\text {rd }}$ ed. Apen Law \& Business: New York, 1999. p. 339)

${ }^{62}$ Suprema Corte de Minnesota, 222 N.W.2d 71 Miller v. Miller, Justice Rogosheske, 20 set. 1974. Disponível em: <https://law.justia.com/cases/minnesota/supreme-court/1974/43759-1.html>. Acesso em 07 nov. 2017.
} 
enquanto ocupavam cargo de administração na companhia, sociedades por eles controladas para a utilização de oportunidades comerciais da Miller Waste Mills.

Em instâncias inferiores, os pedidos do autor da ação haviam sido negados sob o argumento de que a maioria das oportunidades comerciais apresentadas não pertencia à Miller Waste Mills, e as que pertenciam haviam sido transferidas às empresas dos réus de boa-fé, com a ratificação das operações por diretores e acionistas da Miller Waste Mills.

No julgamento do recurso apresentado pelo autor da ação, a Suprema Corte de Minnesota analisou os precedentes das cortes americanas que estabeleceram os testes de verificação de uma oportunidade comercial. Deixando expresso o objetivo de melhorar o subjetivismo dos testes até então desenvolvidos, a Suprema Corte desenvolveu um processo de análise em dois passos (two step analysis), combinando o Fairness Test com o Line of Business Test.

O two step analysis se apresentava da seguinte forma: primeiro determinava-se se a oportunidade estava inserida na linha de negócios da companhia, como era feito no Line of Business Test; em seguida, eram feitas considerações sobre condições justas anteriores, no momento e após a aquisição realizada pelo administrador, importando o pensamento desenvolvido no Fairness Test.

Aplicando os dois passos ao caso concreto, a Suprema Corte de Minnesota manteve a decisão anterior, seja porque as oportunidades não estavam intrinsicamente conectadas à linha de negócios Miller Waste Mills, seja porque os administradores não foram desleais ou agiram de má-fé no aproveitamento das oportunidades.

Apesar da tentativa de garantir maior objetividade no teste de verificação das oportunidades comerciais, O’Kelley e Thompson afirmam 
que o método misto apenas sobrepôs a subjetividade e incerteza do Fairness Test sobre a fragilidade do Line of Business Test ${ }^{63}$.

A despeito dos problemas apresentados por todos os testes de verificação pretendidos pela jurisprudência americana, a corporate opportunity doctrine promove importante papel na demonstração de que as pessoas que mantém relação fiduciária intrínseca à sua atividade para com a companhia não podem servir a interesses pessoais contrapostos com o da companhia. As diversas tentativas de delimitar testes de verificação para a caracterização de usurpação de oportunidades comerciais são meros esforços para limitar as hipóteses em que o administrador está impedido de perquirir seus anseios pessoais.

\subsection{Responsabilidade do acionista controlador na corporate opportunity doctrine}

A partir da análise do desenvolvimento da corporate opportunity doctrine permanece a dúvida da aplicabilidade da vedação à utilização de oportunidades comerciais pelos acionistas controladores nos Estados Unidos. Todos os casos paradigmáticos que foram analisados no item 2.1 acima enfrentaram a responsabilidade de administradores por quebra de seu dever de lealdade, como agentes que mantém relação de fidúcia para com a companhia na administração de um patrimônio alheio.

A principal questão é se acionistas controladores, na condição de detentores do poder de controle e, portanto, liberdade para determinar a direção dos negócios sociais, podem também ser considerados como agentes sujeitos à vedação à exploração de oportunidades comerciais condizentes com os negócios da companhia por eles controlada.

\footnotetext{
63 "In fact, the test adopted in Miller merely piles the uncertainty and vagueness of the fairness test on top of the weakness in the line of business test." Em tradução livre: "De fato, o teste adotado em Miller simplesmente faz pilas a incerteza e a imprecisão do fairness test em cima da fraqueza do line of business test." (O'KELLEY, Charles Rogers Taber. THOMPSON, Robert B. Corporations and other business associations: cases and materials. $3^{\text {rd }}$ ed. Apen Law \& Business: New York, 1999. p. 339).
} 
A análise da doutrina e jurisprudência americana, assim como de especialistas brasileiros que se debruçaram sobre a corporate opportunity doctrine, nos mostra que a regra é de que os acionistas controladores não estão sujeitos à responsabilidade por exploração de oportunidades comerciais. James Slaughter afirma:

An ordinary shareholder, for purposes of the corporate opportunity doctrine, is treated differently from a director or officer. Ownership and management are divorced in the modern corporation. Most stockholders do not occupy strategic corporate positions through which they can obtain profitable opportunities at the expense of their corporation. Furthermore, stockholders are not in a fiduciary relationship to their corporation such as to impose upon them a duty of loyalty toward their corporation. Therefore, in the absence of their domination or usurpation of the functions of the board of directors, thereby making themselves responsible for the action or inaction of the directors, there should be no shareholder liability under the corporate opportunity doctrine.$^{64}$ (grifos nossos)

Entretanto, como toda regra, essa também admite exceção, que é verificada quando o acionista controla a administração da companhia e, portanto, passa a atuar indiretamente como administrador, atraindo os deveres e responsabilidades inerentes à função:

Several cases have held shareholders liable for diversion of corporate opportunities when the shareholders were found to have controlled or dominated the board of directors and hence have assumed the directors' liability. See Perlman v. Feldman, 219 F.2d 173 (2d Cir. 1955); Lebold v. Inland Steel Co., 125 F.2d 369 (7th Cir. 1941); Austrian v. Williams, 103 F. Supp. 64 (S.D.N.Y. 1952), rev'd on other grounds, 198 F.2d 697 (2d Cir. 1952). "' Carrington \& McElroy, supra note 6, at $965 .^{65}$

64 SLAUGHTER, James C. The Corporate Opportunity Doctrine. Disponível em: $<$ http://scholar.smu.edu/cgi/viewcontent.cgi?article=4215\&context=smulr $>$. Acesso em 07 nov. 2017.. Em tradução livre: "Um acionista comum, para fins da corporate opportunity doctrine, é tratado de maneira diferente de um diretor ou conselheiro. A propriedade e a administração são divorciadas na corporação moderna. A maioria dos acionistas não ocupa posições estratégicas corporativas através das quais podem obter oportunidades lucrativas à custa da companhia. Além disso, os acionistas não estão em um relacionamento fiduciário com sua companhia, de modo a impor-lhes o dever de fidelidade em relação à companhia. Portanto, na ausência de sua dominação ou usurpação das funções da administração, tornando-se responsáveis pela ação ou inércia dos diretores, não deve haver responsabilidade de acionistas sob a luz da corporate opportunity doctrine."

65 SLAUGHTER, James C. The Corporate Opportunity Doctrine. Disponível em: $<$ http://scholar.smu.edu/cgi/viewcontent.cgi?article=4215\&context=smulr $>$. Acesso em 07 nov. 2017.. Em tradução livre: "Vários casos responsabilizaram os acionistas pelo desvio de 
A própria ex-Diretora da CVM, Ana Novaes, - que como se verá mais adiante, no Capítulo 3, se posiciona pela possibilidade de responsabilização de acionistas controladores por usurpação de oportunidade comercial afirma que no Direito americano o controlador não está impedido de explorar atividade relacionada aos negócios da companhia, a não ser que utilize sua posição como controlador para se aproveitar de uma oportunidade de negócio:

16. No direito norte-americano, diferentemente dos administradores, o acionista controlador não está sujeito à obrigação de não competir com a companhia. Contudo, se o controlador usa sua posição como controlador para se aproveitar de uma oportunidade de negócio, impedindo a companhia de fazê-lo, ele terá violado o seu dever fiduciário para com a companhia. Neste último caso, o direito americano muito se assemelha ao brasileiro. O direito americano desenvolveu passos que o julgador deve considerar ao avaliar a ocorrência ou não da usurpação de uma oportunidade. ${ }^{66}$ (grifos nossos)

Considerando as devidas diferenças entre o Direito americano e o brasileiro, assim como os diferentes estágios de maturação dos mercados de capitais nos dois países, me parece que esta é a melhor interpretação a respeito da responsabilidade dos controladores.

Em regra, a posição por eles ocupada não exige um padrão maior de lealdade equiparável ao dos administradores, como vem sendo sustentado pela doutrina brasileira. Os acionistas controladores estão livres para explorar as oportunidades que sejam a eles pertencentes, como se observou no Capítulo 1 acima, mas responderam quando utilizarem de sua posição de controle para usurpar uma oportunidade que se apresentava como da companhia, e não do grupo controlador.

\footnotetext{
oportunidades comerciais quando os acionistas foram classificados como controlados ou dominados pelo conselho de administração e, portanto, assumiram a responsabilidade dos diretores. Ver Perlman v. Feldman, 219 F.2d 173 (2d Cir. 1955); Lebold v. Inland Steel Co., 125 F.2d 369 ( $7^{\circ}$ Cir. 1941); Austrian v. Williams, 103 F. Supp. 64 (S.D. N.Y. 1952), rev.d por outros motivos, 198 F.2d 697 (2d Cir. 1952). "Carrington \& McElroy, supra nota 6, às 965."

${ }^{66}$ CVM, PAS CVM RJ2012/10487, Rel. Ana Dolores Moura Carneiro de Novaes, Rio de Janeiro, 5 nov. 2013.
} 


\section{CAPÍTULO 3 - APLICAÇÃO DA VEDAÇÃO À USURPAÇÃO DE OPORTUNIDADE COMERCIAL NO DIREITO BRASILEIRO}

Apesar das considerações feitas no Capítulo 1, acerca do regime de responsabilidade de acionistas controladores no Direito brasileiro, e no Capítulo 2, acerca do sistema americano que inspirou a doutrina e jurisprudência brasileiras, a garantia de liberdade ao acionista controlador para explorar as oportunidades a ele pertencentes não vem sendo a posição predominante no Brasil.

O principal foro de discussão acerca da responsabilização de acionistas controladores por usurpação de oportunidades comerciais de suas controladas é, atualmente, o Colegiado da Comissão de Valores Mobiliários - CVM, órgão regulador das companhias abertas no Brasil e o "tribunal" responsável pela análise de algumas das maiores operações envolvendo companhias brasileiras de capital aberto.

Abaixo será abordado, criticamente, cada um dos casos de usurpação de oportunidades comerciais já levados à apreciação do Colegiado da CVM, o fundamento preponderante para as decisões da autarquia e o meio processual administrativo utilizado pela CVM para abordar questão controversa e ainda não pacificada na jurisprudência administrativa.

\subsection{Jurisprudência da Comissão de Valores Mobiliários}

Inicia-se a análise detida de cada um dos casos julgados pela CVM, passando pela breve descrição do histórico do processo e os fundamentos utilizados pelos membros do Colegiado da autarquia para sua tomada de decisão.

Alguns dos casos analisados abaixo possuem discussão mais profunda e complexa, abordando, muitas vezes, diversas questões polêmicas do Direito societário que fogem do escopo de discussão deste trabalho. Neste sentido, o trabalho se limitará a apresentar as discussões relacionadas à usurpação de 
oportunidade comercial, sem entrar no mérito dos demais assuntos enfrentados pelo Colegiado nestes processos.

\subsubsection{Caso AMBEV (Processo CVM RJ2004/5494)}

O primeiro caso de usurpação de oportunidade comercial analisou uma das etapas de expansão dos negócios da maior companhia do ramo cervejeiro brasileiro.

No ano de 2004, os acionistas controladores da AMBEV promoveram operação de permuta de suas ações por ações de emissão da Interbrew S.A. e a incorporação de Labatt Brewing Canadá Holding Ltd. pela AMBEV.

Diante da operação de permuta e de incorporação, a Caixa de Previdência dos Funcionários do Banco do Brasil S/A - PREVI, acionista minoritária da AMBEV, apresentou reclamação perante a CVM contra a companhia e seus acionistas controladores, alegando, em linhas gerais, a existência de (i) abuso do poder de controle; (ii) conflito de interesses dos administradores e controladores; (iii) usurpação de oportunidade comercial; e (iv) falha na divulgação de informações ao mercado a respeito da operação.

Após decisão da Superintendência de Relações com Empresas -SEP da CVM entendendo pela inexistência de "evidências suficientes a caracterizar a operação em questão como lesiva e a justificar a necessidade de instauração de procedimento administrativo sancionador", a PREVI apresentou recurso ao Colegiado da CVM contra tal decisão.

Especificamente com relação à usurpação de oportunidade comercial a PREVI alegava que não poderia ser afastada a aplicação do inciso I do art. 155 da LSA pois os controladores da AMBEV também seriam seus administradores, razão pela qual estariam impedidos de explorar a oportunidade ou deveriam, ao menos, tê-la apresentado para deliberação da companhia. Também alegou a PREVI que os controladores, ao explorarem diretamente a oportunidade, teriam faltado com seu dever de lealdade, usurpando oportunidade pertencente à companhia. 
Em suas razões de voto, o Diretor Relator Wladimir Castelo Branco afastou a incidência da usurpação de oportunidade comercial por entender que o inciso I do art. 155 pressupõe que a "oportunidade tenha sido anteriormente apresentada à companhia".

Entendeu o Diretor Relator que a operação questionada "foi diretamente apresentada aos controladores da AMBEV, não na qualidade de administradores, mas na de detentores do poder de controle dessa companhia". Portanto, para o Diretor Wladimir Castelo Branco, somente se configuraria usurpação de oportunidade comercial quando (i) a oportunidade fosse da companhia, tendo sido previamente a ela oferecida, e (ii) os administradores tomassem tal oportunidade e a explorassem diretamente, fora do âmbito da companhia.

Com a devida vênia ao então Diretor Wladimir Castelo Branco, concordo apenas parcialmente com a sua posição.

Primeiramente, considera-se que o inciso I do art. 155 não exige que a oportunidade tenha sido previamente apresentada à companhia para que possa ser usurpada. Aos administradores de companhias é expressamente prevista a vedação à utilização de oportunidades comerciais "de que tenha conhecimento em razão do exercício de seu cargo", não importando se a oportunidade foi oficialmente levada à deliberação da companhia ou não.

Com relação à apresentação da oportunidade diretamente aos controladores na qualidade de detentores do poder de controle, e não de administradores, reforço o posicionamento defendido no item 1.2 acima. $\mathrm{Na}$ maioria das vezes é extremamente difícil determinar em que qualidade uma pessoa teve conhecimento da oportunidade questionada, se na posição de administrador ou de controlador de uma companhia.

Um administrador não "veste a capa" de administrador apenas no interregno de tempo em que está dentro da companhia, exercendo as funções inerentes a seu cargo durante todo o tempo. Enquanto ocupante deste cargo, 
o administrador estará sujeito aos deveres e responsabilidades a ele atribuídos.

A única prova capaz de afastar a responsabilidade de um administrador/controlador que explora diretamente oportunidade que poderia ter sido utilizada pela companhia é a que demonstra que a operação foi a ele oferecida apenas na qualidade de acionista controlador, e não de administrador.

O Caso AMBEV demonstrou uma hipótese em que tal prova pode ser construída.

O então presidente da CVM, Marcelo Trindade, apresentou visão prática acerca da operação que elucida a sua estruturação voltada para os acionistas controladores da AMBEV:

Concordo com o Diretor Relator no sentido de que não há indícios de ocorrência de tal violação, pois em verdade o negócio celebrado (alienação de controle da Ambev, com reestruturação societária) seria provavelmente inviável, ao menos nas bases em que realizado, caso se desse como pretendido pelos reclamantes - isto é, no nível da própria Ambev, com sua incorporação à Interbrew, ou vice-versa.

\section{$[\ldots]$}

É claro que a área técnica sempre poderá colher depoimentos dos envolvidos, para tentar encontrar algum indício de que os administradores de Ambev tenham recebido uma proposta como a antes referida, e a tenham recusado, mas hoje não há nenhum indício, considerados os aspectos de fato do caso, de que as coisas tenham se passado como pensam os reclamantes.

No mundo real, este negócio tem aparência de ter sido concebido, desde o começo, como o que foi (não importando o formato final): um negócio entre controladores, com repercussão para a companhia, como ocorreu em inúmeras operações de alienação de controle em empresas fortemente alavancadas, isto é, com grande parte de seu capital em ações preferenciais sem voto (no caso de Ambev, quase $60 \%$ do capital social).

\section{$[\ldots]$}

Foi isto que aparentemente aconteceu neste caso: a sociedade controladora de Ambev apropriou-se de tal mais valia através da alienação, por permuta, das ações de controle de Ambev para os controladores de Interbrew. E este negócio não era 
um negócio possível para a própria Ambev, seja porque ela não detinha este direito, que apenas os controladores detinham, seja porque tal negócio somente seria viável sem perda do controle de Interbrew (adotadas as relações de troca estabelecidas) se realizado apenas com alguns dos acionistas de Ambev (os controladores e, no máximo, os titulares de ações ordinárias, caso aceitem a oferta de permuta, decorrente da alienação de controle). (grifos nossos)

Percebe-se, portanto, que o então Presidente e o Diretor Relator consideraram que a operação foi estruturada e planejada para os acionistas controladores da AMBEV, e não para a companhia em si. Não havendo oportunidade para a companhia, não há de se falar em usurpação da mesma, estando correto o posicionamento vencedor pela inexistência de usurpação de oportunidade comercial pelos acionistas controladores da AMBEV.

Apesar dos votos vencedores acima mencionados, é preciso apresentar também as razões do voto dissidente da então Diretora Norma Parente, que entendeu pela existência de usurpação de oportunidade comercial pelos acionistas controladores da AMBEV.

\section{Para a Diretora:}

Haja vista o fato de os controladores da AMBEV serem, também, administradores da empresa, não haveria como afirmar que a operação fora proposta apenas aos controladores e não à companhia como um todo. ${ }^{67}$

Nesta linha, a Diretora se socorre à corporate oportunity doctrine para sustentar a responsabilização dos controladores/administradores com base no art. 155, inciso I da LSA:

25. A lei societária pátria, contudo, não detalha a maneira de se verificar, in concreto, quando ocorre o ilícito, motivo pelo qual se deve recorrer ao direito comparado.

26. Assim, com base na doutrina e jurisprudência norte-americana, tem se entendido que, para que fique caracterizada a usurpação de oportunidade comercial pelo administrador, basta que a companhia tenha um interesse real ou potencial na transação. Com isso, transferiu-se ao administrador interessado o ônus de

${ }^{67}$ CVM, PAS CVM RJ2012/10487, Rel. Ana Dolores Moura Carneiro de Novaes, Rio de Janeiro, 5 nov. 2013. 
provar, através de metodologia apropriada - elaboração de estudos, laudos, pareceres, etc.-, a legitimidade da utilização da oportunidade comercial.

27. Conclui-se, então, que, sempre que o negócio se relacionar à atividade social, a usurpação da oportunidade pelo administrador, em detrimento da companhia, é presumida, só não sendo ilegítimo o aproveitamento, nos casos em que: (i) a companhia não possuir recursos financeiros para aproveitá-la; (ii) estiver proibida de realizar negócios daquela natureza; (iii) o estatuto da companhia não permitir a realização daquele negócio; (iv) ou quando a companhia já tenha recusado a referida oportunidade, previamente oferecida.(15)

28. O ordenamento norte-americano(16) autoriza, ainda, o administrador a utilizar a oportunidade do negócio, se (i) tal utilização for justa para a companhia, (ii) previamente autorizada ou ratificada por acionistas desinteressados e caso essa utilização não represente perda patrimonial para a companhia.

29. De uma análise perfunctória do caso concreto, evidenciam-se os elementos caracterizadores do ilícito. A uma porque, no caso, o controlador de AMBEV é, também, administrador da companhia, tendo tomado ciência da oportunidade da Permuta de ações com a companhia belga, anteriormente a todos os outros acionistas. Por conseguinte, está sujeito à determinação do artigo 117, parágrafo $3^{\mathbf{o}}$, da $\operatorname{LSA}(17)$. A duas porque, não constam, nos autos do presente processo administrativo, quaisquer documentos ou estudos que forneçam respaldo à utilização legítima pelo administrador, enquanto controlador de AMBEV, da oportunidade relativa à operação de permuta de suas ações de controle com aquelas de INTERBREW, já que a referida oportunidade comercial, sequer fora apresentada à companhia. ${ }^{68}$ (grifos nossos)

O raciocínio da Diretora segue na linha de que, no caso concreto, não seria possível dissociar a atuação dos acionistas controladores enquanto titulares do poder de controle da atuação dos mesmos enquanto administradores da companhia. Em razão do art. $117, \S 3^{\circ}$ da $\operatorname{LSA}^{69}$, o controlador estaria sujeito ao mesmo dever fiduciário de lealdade imposto aos administradores e, por conseguinte, à vedação à usurpação de oportunidade comercial presente no art. 155, inciso I da LSA.

Como vimos, o raciocínio da Diretora não está de todo equivocado, visto que na maioria das situações é impossível dissociar a atuação de determinado agente como acionista controlador ou administrador da

\footnotetext{
${ }^{68}$ CVM, PAS CVM RJ2012/10487, Rel. Ana Dolores Moura Carneiro de Novaes, Rio de Janeiro, 5 nov. 2013.

69 " $§ 3^{\circ} \mathrm{O}$ acionista controlador que exerce cargo de administrador ou fiscal tem também os deveres e responsabilidades próprios do cargo." (Disponível em: <http://www.planalto.gov.br/ccivil_03/leis/L6404consol.htm> Acesso em: 07 nov. 2017.)
} 
companhia. Entretanto, quando os fatos do caso nos permitem inferir que a oportunidade foi desenvolvida e concebida para ser explorada pelos acionistas controladores, é possível estabelecer esta distinção e concluir que a oportunidade nunca pertenceu à companhia.

Em linha com o voto apresentado pelo então Presidente Marcelo Trindade, considera-se que, no caso concreto, a operação de permuta de ações foi idealizada para ser um negócio entre controladores, sendo inclusive inviável no âmbito da própria AMBEV. Considerando a realidade fática, pode-se concluir que não restou caracterizada a usurpação de oportunidade comercial pelos acionistas controladores, ainda que ocupassem cargos também na administração da Companhia.

\subsubsection{Caso M\&G Poliéster (PAS CVM RJ2008/1815)}

Este processo analisou a conduta dos acionistas controladores da M\&G Poliéster pela constituição, de forma individual e sem oferecimento prévio à sua controlada, de sociedade concorrente à companhia.

A M\&G Poliéster era companhia aberta destinada, principalmente, à produção de resina PET para embalagens e de fibras de poliéster para indústria têxtil. Por sua vez, a M\&G Polímeros era sociedade anônima de capital fechado, controlada indiretamente pelos mesmos acionistas controladores da M\&G Poliéster, e também destinada à produção de resina.

A investigação por parte da CVM teve início em fevereiro de 2007, a partir de consultas e reclamações apresentadas por acionistas minoritários $\mathrm{M} \& \mathrm{G}$ Poliéster questionando "a inauguração de nova fábrica de resina PET, no complexo de Suape, PE, através da M\&G Polímeros, e sua influência nos negócios da M\&G Poliéster"70.

Em julho do mesmo ano, o Conselho de Administração da M\&G Poliéster decidiu submeter à Assembleia da companhia uma proposta de

\footnotetext{
${ }^{70}$ Trecho extraído do relatório do Diretor-Relator Eli Loria no âmbito do PAS CVM N RJ2008/1815.
} 
incorporação da M\&G Polímeros, a qual foi aprovada por AGE realizada em 25 de julho de 2007.

Após análise dos fatos, a Superintendência de Relações com Empresas - SEP, componente organizacional da CVM, entendeu que restou comprovada, entre outros ilícitos, a conduta irregular do acionista controlador da M\&G Poliéster "por constituir sociedade concorrente à Companhia sem antes ter lhe oferecido parceria no novo empreendimento", elaborando Termo de Acusação para apreciação do Colegiado da CVM.

Primeiramente, é preciso ressaltar que a mera análise de uma potencial responsabilidade de um acionista controlador por usurpação de oportunidade comercial no âmbito de um processo administrativo sancionador, sem nunca ter havido posicionamento final da CVM pela possibilidade de caracterização de tal infração, representa grave afronta ao princípio da vedação à aplicação de nova interpretação em processos sancionadores, como será visto no item 3.3.1 abaixo.

Pela primeira vez, o Colegiado da CVM reconheceu expressamente a possibilidade de condenação de acionistas controladores por usurpação de oportunidades comerciais, com base no dever de lealdade contido na regra geral do art. 116, parágrafo único, da $\mathrm{LSA}^{71}$.

Para chegar a tal conclusão, o Colegiado considerou que o dever de lealdade esperado dos controladores é o mesmo dever fiduciário imposto aos administradores. Nas palavras do Diretor Relator, Eli Loria:

\footnotetext{
Assim, pela especialidade da função de controlador, pela sua relação intrínseca com o próprio desenvolvimento da companhia, bem como com os interesses dos sócios, compreende-se que se aplicam também a ele controlador o mesmo dever de lealdade desvelado pelo diploma societário aos administradores. ${ }^{72}$
}

\footnotetext{
71 “Art. 116, Parágrafo único, LSA. O acionista controlador deve usar o poder com o fim de fazer a companhia realizar o seu objeto e cumprir sua função social, e tem deveres e responsabilidades para com os demais acionistas da empresa, os que nela trabalham e para com a comunidade em que atua, cujos direitos e interesses deve lealmente respeitar e atender." (Disponível em: <http://www.planalto.gov.br/ccivil 03/leis/L6404consol.htm> Acesso em: 07 nov. 2017.)

${ }^{72}$ CVM, PAS CVM RJ2008/1815, Rel. Eli Loria, Rio de Janeiro, 28 abr. 2009.
} 
Utilizando-se dessa premissa, o Diretor Relator se socorreu à doutrina americana do corporate opportunity doctrine para concluir que os acionistas controladores não poderiam ter constituído empresa concorrente à companhia, usurpando oportunidade a ela pertencente:

Com lastro na doutrina estadunidense, reconhece-se como oportunidade comercial aquela: (i) da qual a companhia seja financeiramente capaz de usufruir; (ii) que seja essencialmente comum aos negócios da empresa; (iii) que represente vantagem efetiva aos negócios; e (iv) em relação à qual a companhia tenha interesse ou expectativas razoáveis. Ademais, deixa de ser considerada como tal a oportunidade da qual a companhia não seja capaz de se beneficiar. Assim, caso a hipótese envolva administrador, considera-se usurpação de oportunidade quando este possua interesse individual conflitante com o da companhia e aceita a oportunidade com vistas a seu benefício próprio.

À companhia deve ser dada a oportunidade de decidir se deve, ou não, investir em uma nova oportunidade de negócio; seja ela diretamente relacionada às suas atividades atuais, ou com vistas a novas operações. Dessa maneira, a doutrina estadunidense entende que é dever dos administradores divulgarem de maneira completa todas as informações sobre os fatos relacionados à oportunidade em questão, de modo que todas as circunstâncias do negócio sejam de conhecimento da companhia.

No presente caso, percebe-se que o controlador, ao decidir constituir nova companhia para a exploração de atividade semelhante à da M\&G Poliéster, em função da necessidade de atender demanda crescente de resina PET e de fibras de poliéster, não apresentou devidamente a referida oportunidade aos administradores daquela companhia.

\section{$[\ldots]$}

Acrescente-se que o argumento de incapacidade econômica da M\&G Poliéster para levar a cabo um projeto de ampliação industrial carece de verossimilhança, ante a decisão de incorporação das ações da $M \& G$ Polímeros, uma vez que tal ação resultaria, necessariamente, em um aumento significativo de capital da incorporadora. Daí a conclusão de que sempre houvera a possibilidade de capitalização na empresa e disso ela foi privada, em prejuízo de seus acionistas minoritários.

\section{$[\ldots]$}

No caso em comento, a oportunidade fora criada pelo grupo controlador e pertencia, por clara questão de afinidade de objeto social, à M\&G Poliéster. Ademais, é de se ressaltar que, com lastro no assentado na jurisprudência estadunidense, o meu entendimento acerca do conceito de usurpação de 
oportunidade comercial engloba a situação pelo qual esta se concretiza tão logo exista um interesse real ou potencial da companhia na transação.

\section{$[\ldots]$}

Pode-se concluir que a operação empreendida gerou um benefício econômico para o acionista controlador através do aumento da sua participação acionária na empresa $M \& G$ Poliéster e consequente redução da participação dos minoritários restando claro, pois, o ato abusivo, clara a usurpação de oportunidade negocial e clara a quebra do dever de lealdade que, conforme explicitado acima, informa a relação entre acionista controlador e companhia. ${ }^{73}$

Com a devida vênia ao Diretor Relator, permito-me discordar.

Analisou-se no Capítulo 1 acima que a intenção do legislador não parece ter sido a de conferir o mesmo tratamento ao dever de lealdade de acionistas controladores e administradores. O ordenamento jurídico brasileiro e a regulação do mercado de capitais em nenhum momento restringem ou vedam o controle de mais de uma empresa do mesmo setor, verificando-se como expressão da liberdade de iniciativa de acionistas controladores a decisão de explorar no âmbito das companhias por eles controladas ou fora dele as oportunidades que são a eles - acionistas controladores - fornecidas ou desenvolvidas.

O cumprimento do objeto social, standard de atuação do acionista controlador presente no art. 116, parágrafo único, da LSA, foi utilizado pelo então Diretor Marcos Pinto para justificar a vedação ao controlador de utilização das oportunidades concorrentes com a companhia:

2.2 No direito brasileiro, essas perguntas têm uma resposta clara. O parágrafo único do art. 116 da Lei $\mathrm{n}^{\mathrm{o}}$ 6.404, de 15 de dezembro de 1976, estabelece que o acionista controlador deve "usar o seu poder com o fim de fazer a companhia realizar o seu objeto social". Segue que o controlador não pode explorar individualmente certas oportunidades empresariais, pois isso pode impedir ou dificultar a realização do objeto social. ${ }^{74}$

\footnotetext{
${ }^{73}$ CVM, PAS CVM RJ2008/1815, Rel. Eli Loria, Rio de Janeiro, 28 abr. 2009.
}

${ }^{74}$ CVM, PAS CVM RJ2008/1815, Rel. Eli Loria, Rio de Janeiro, 28 abr. 2009. 
A meu ver, a utilização de oportunidades oferecidas diretamente ao acionista controlador ou por ele desenvolvidas não impede ou dificulta a realização do objeto social da companhia. A companhia seguia seus rumos empresariais antes do surgimento da oportunidade e continuará a perquirir seu objeto social após a oportunidade, mesmo que não seja ela o veículo utilizado para a exploração da oportunidade.

Considera-se que a regra contida no art. 116, parágrafo único, da LSA, veda o acionista controlador de dirigir a companhia para o desenvolvimento de atividade econômica estranha àquela prevista em seu objeto social, mas não de explorar paralelamente atividade que esteja inserida no objeto social da controlada.

Justamente por não haver relação direta entre a utilização de oportunidade pelo controlador com o desenvolvimento do objeto social pela companhia é que o critério de alocação de oportunidades não deve ser o objeto social, como sustentou o Diretor da CVM. As oportunidades devem pertencer a quem são oferecidas ou por quem são desenvolvidas. Se oferecidas aos administradores, pertencerão à companhia. Se oferecidas exclusivamente aos controladores, serão a eles pertencentes.

Em seu voto, o Diretor Marcos Pinto também defende que:

A relação societária não é uma relação comum de mercado, em que as partes são livres para perseguir seus interesses particulares" e que "o controlador tem uma relação de fidúcia para com os demais acionistas; ele tem o dever de atuar no interesse da companhia. ${ }^{75}$

Em verdade, o acionista controlador, como qualquer acionista, é livre para perquirir seus objetivos e anseios pessoais, desde que tais interesses não sejam contrários ao interesse da companhia. Neste sentido, é esclarecedor o voto do Conselheiro Relator do Recurso do Caso M\&G Poliéster ao CRSFN:

Não considero que esses deveres compreendam a obrigação de estender aos demais acionistas as oportunidades de negócio que sejam próprias do controlador. E, nesse

${ }^{75}$ CVM, PAS CVM RJ2008/1815, Rel. Eli Loria, Rio de Janeiro, 28 abr. 2009. 
aspecto, considero que o predicado dado à irregularidade, ou seja, "sem o oferecimento da oportunidade comercial à sua controlada companhia aberta", não foi colocado adequadamente.

No meu entendimento, o controlador não faz um pacto perene de parceria com as sociedades que controla e seus acionistas minoritários. Sendo controlador do empreendimento A, no ramo automotivo, pode decidir por abrir novas frentes de negócio no ramo imobiliário, ou agroindustrial, ou bancário, como ocorre com várias pessoas e holdings, no País e afora, desde que não interfira na esfera de interesses das controladas, gerando potencial prejuízo aos demais sócios dessas empresas. Desse modo, o tema da falta de oferecimento da oportunidade comercial deve ser afastado, para que não se ponha mais confusão no que se pretende julgar. ${ }^{76}$ (grifos nossos)

A exploração de oportunidades pertencentes, única e exclusivamente, aos acionistas controladores - que nunca foram oferecidas aos administradores da companhia - não viola esta regra, uma vez que o acionista estará buscando um interesse pessoal fora do âmbito da companhia e, portanto, não estará atuando como um órgão da companhia, em decisões com repercussões diretas para a atividade da companhia.

Também não há como concordar que exista a chamada relação de fidúcia entre acionistas controladores e acionistas minoritários. $\mathrm{O}$ acionista controlador não é um gestor de patrimônio alheio, não toma as decisões do dia-a-dia da companhia, apenas orienta de forma global os negócios sociais. Para esta atuação não existe relação de fidúcia, limitada aos que exercem a administração da companhia.

Em outra passagem de seu voto, o Diretor Marcos Pinto argumenta:

Os investidores compram ações com base nas perspectivas de crescimento e rentabilidade da companhia. Obviamente, o controlador não pode frustrar propositalmente essas expectativas, tomando para si projetos rentáveis e privando a companhia de suas oportunidades de crescimento. ${ }^{77}$

Concordo com a primeira parte do raciocínio do diretor. Certamente, muitos investidores repensarão sua participação na companhia ao terem conhecimento de que o acionista controlador utilizou diretamente

\footnotetext{
${ }^{76}$ CVM, PAS CVM RJ2008/1815, Rel. Eli Loria, Rio de Janeiro, 28 abr. 2009.

${ }^{77}$ CVM, PAS CVM RJ2008/1815, Rel. Eli Loria, Rio de Janeiro, 28 abr. 2009.
} 
determinada oportunidade comercial que poderia ter sido explorada pela companhia.

Entretanto, a saída para este problema não está na proibição da utilização legítima de oportunidades pertencentes ao controlador mas na melhora da qualidade informacional, que resultará em uma precificação de mercado da companhia condizente com a atuação do controlador.

Aos investidores que não enxergarem prejuízo na utilização da oportunidade pelo controlador, esta será uma oportunidade de entrada a um preço por ação provavelmente mais barato. Aos que não concordarem com a atuação direta do controlador, e enxergarem na perda da oportunidade um prejuízo para a companhia, esta será uma motivação para a saída da companhia.

De uma forma ou de outra, o mercado precifica cada uma das situações autonomamente, como veremos no Capítulo 4 abaixo.

A despeito das observações feitas acima a respeito da utilização direta, por parte do controlador, da oportunidade comercial discutida no Caso $M \& G$ Poliéster, os contornos fáticos eram muito mais abrangentes do que a simples análise de uma utilização de oportunidade comercial.

Se, no caso concreto, a operação posterior de incorporação da $M \& G$ Poliéster na $M \& G$ Polímeros se mostrou de alguma forma prejudicial ao interesse da companhia aberta, a análise deverá ser pautada única e exclusivamente nesta deliberação, com a utilização dos institutos de abuso do poder de controle, conflito de interesses, entre outros já existentes na nossa LSA para a resolução destas situações.

Não está, entretanto, na decisão de constituição de sociedade concorrente à companhia aberta a suposta ilegalidade no caso concreto, uma vez que a decisão dos acionistas controladores da M\&G Poliéster não resultou em dificuldade no cumprimento de seu objeto social, sua função social, ou do dever de lealdade esperado desses acionistas. 
O julgamento do recurso dos controladores da M\&G Poliéster no CRSFN passou, de certa forma, por essa discussão. Apesar de ter afastado o tema da falta de oferecimento de oportunidade comercial pelo acionista controlador por entender que o acionista controlador não está obrigado a oferecer à companhia oportunidades a ele pertencentes ${ }^{78}$, o Conselheiro Relator do recurso, Johan Albino Ribeiro, considerou que a atuação do controlador havia causado prejuízos para a companhia aberta, caracterizando a falta de seu dever de lealdade:

Contudo, como indicado acima, a irregularidade foi caracterizada pela falta de lealdade do controlador à companhia, e tudo que gira em torno dela, quando decidiu pela construção de uma planta industrial concorrente. ${ }^{79}$ (grifos nossos)

O Conselheiro Relator votou, então, pelo parcial provimento do recurso dos acionistas controladores, concordando com a condenação por infração ao dever de lealdade (apesar de ter discordado dos fundamentos) e votando pela diminuição da multa em razão da impossibilidade de calculá-la mediante aferição da vantagem econômica obtida pelos controladores, como havia feito a CVM:

Pelo que temos neste caso, a controladora não foi chamada para justificar a incorporação, o que permitiria a utilização do inciso II, do $\S 1^{\circ}$. do art. 11 , da Lei $6.385 / 76$, qual seja $50 \%$ do valor da operação. Também não se discutiu a vantagem econômica obtida pelo Grupo Mossi \& Ghisolfi, ponderada com os riscos e garantias aportadas para a realização do novo empreendimento, o que permitiria a aplicação do inciso III, do mesmo dispositivo legal, ou seja, três vezes a vantagem econômica. Assim, o único critério objetivo, para a aplicação de multa, é o valor máximo de $\mathrm{R} \$ 500.000,00$ (quinhentos mil reais). ${ }^{80}$ (grifos nossos)

\footnotetext{
${ }^{78}$ Nos termos do voto apresentado pelo Conselheiro Relator Johan Albino Ribeiro, no julgamento do Recurso 12709, analisado na $333^{\text {a }}$ sessão de julgamento do CRSFN, realizada em 29 de junho de 2011: "Não considero que esses deveres compreendam a obrigação de estender aos demais acionistas as oportunidades de negócio que sejam próprias do controlador. E, nesse aspecto, considero que o predicado dado à irregularidade, ou seja, "sem o oferecimento da oportunidade comercial à sua controlada companhia aberta", não foi colocado adequadamente. [...] Desse modo, o tema da falta de oferecimento da oportunidade comercial deve ser afastado, para que não se ponha mais confusão no que se pretende julgar.” (grifos nossos). CRSFN, Recurso 12709, Rel. Johan Albino Ribeiro, Brasília, 09 nov. 2011.

${ }^{79}$ CRSFN, Recurso 12709, Rel. Johan Albino Ribeiro, Brasília, 09 nov. 2011.

80 CRSFN, Recurso 12709, Rel. Johan Albino Ribeiro, Brasília, 09 nov. 2011.
} 
O provimento parcial do recurso com a modificação do método de cálculo da multa aplicada aos controladores foi inteiramente acompanhado pelos demais membros do CRSFN.

\subsubsection{Caso CAL (PAS CVM RJ2012/10487)}

O Caso CAL originou-se de reclamação apresentada por acionistas minoritários da Construtora Adolpho Lindenberg ("CAL") que questionavam o abandono, por parte da CAL, da atividade de incorporação imobiliária em benefício de sociedade destinada exclusivamente a este fim, a LDI. A CAL era companhia aberta cujo objeto social abrangia tanto a incorporação imobiliária quanto a construção de imóveis destinados à venda.

Inicialmente, a CAL detinha participação societária de $25 \%$ no capital social da LDI. Entre os anos de 2006 e 2007 esta última sociedade passou por processo de reestruturação societária, com a entrada e aumento de participação de alguns acionistas e a diluição de outros. Durante a reestruturação, a CAL outorgou à LDI exclusividade para atuar no mercado de incorporação imobiliária, atividade expressamente inserida no objeto social da CAL. Em contrapartida, a LDI outorgou à CAL preferência para a construção dos projetos por ela desenvolvidos. Ocorre que, por conta da reestruturação, a participação da CAL no capital social da LDI foi sendo diluída até ser totalmente alienada. Como resultado, a CAL deixou de exercer as atividades de incorporação, concentrando-se na construção de imóveis.

Acontece que os acionistas controladores da CAL subscreveram, diretamente, pequenos percentuais em aumentos de capital realizados durante a reestruturação da LDI. Em 2008 - portanto, após a sua reestruturação - a LDI adquiriu o controle da CAL e realizou oferta pública para aquisição dos demais titulares de ações ordinárias, como prescreve o art. 254-A da LSA ${ }^{81}$. Apenas após a transferência de controle é que a LDI

\footnotetext{
81 “Art. 254-A. A alienação, direta ou indireta, do controle de companhia aberta somente poderá ser contratada sob a condição, suspensiva ou resolutiva, de que o adquirente se obrigue a fazer oferta
} 
promoveu novos aumentos de capital, subscritos pelos antigos acionistas controladores da CAL o que fez com que os mesmos passassem a ter participação relevante na LDI.

Inconformados, os acionistas minoritários interpuseram reclamação perante a CVM questionando o esvaziamento da CAL em favor da LDI, com a participação de controladores e administradores da companhia.

Por entender que a atividade de incorporação imobiliária estava inserida no objeto social da CAL, a área técnica da CVM concluiu que os acionistas controladores continuaram a aproveitar as oportunidades comerciais transferidas à LDI, enquanto os demais acionistas permaneceram privados de tais oportunidades. Neste sentido, a área técnica concluiu que os acionistas controladores haviam descumprido o seu dever de lealdade previsto no art. 116, parágrafo único, da LSA, com a usurpação de oportunidades comerciais da CAL, e elaborou Termo de Acusação em face dos acionistas controladores por entender que:

Um acionista controlador não pode renunciar a uma oportunidade empresarial em favor de outra sociedade e depois vir a participar dessa sociedade, tornando assim a usufruir da oportunidade renunciada, sem obter consentimento dos demais acionistas ou oferecer-lhes iguais chances de também participarem da mesma sociedade. ${ }^{82}$

A Diretora Relatora do caso, Ana Novaes, discordou da Acusação e votou pela absolvição dos acionistas controladores, acompanhada pelos demais membros do Colegiado presentes naquela sessão de julgamento.

A fundamentação utilizada pela Diretora Relatora difere das variáveis enfrentadas até o momento no presente estudo. Apesar de entender que, em regra, "o administrador ou controlador não pode aproveitar oportunidade de negócio que esteja no objeto social da companhia", a diretora entendeu

pública de aquisição das ações com direito a voto de propriedade dos demais acionistas da companhia, de modo a lhes assegurar o preço no mínimo igual a $80 \%$ (oitenta por cento) do valor pago por ação com direito a voto, integrante do bloco de controle." (Disponível em: <http://www.planalto.gov.br/ccivil_03/leis/L6404consol.htm> Acesso em: 07 nov. 2017.)

${ }^{82}$ CVM, PAS CVM RJ2012/10487, Rel. Ana Dolores Moura Carneiro de Novaes, Rio de Janeiro, 5 nov. 2013. 
que a simples listagem de determinada atividade no objeto social da companhia, não necessariamente causa a proibição de utilização de oportunidade correlata por administradores ou acionistas controladores.

Para a Diretora, é preciso que a atividade em questão esteja sendo efetivamente exercida pela companhia ou em vias de ser exercida, assim entendida como a situação em que a companhia está buscando oportunidades para o exercício daquela atividade.

Apesar de manifestar sua opinião de que, em regra, os controladores também estão proibidos de explorar oportunidades que poderiam ser exercidas pela companhia, a Diretora bem apresenta a posição aplicada na corporate opportunity doctrine, doutrina americana que afasta, em regra, a responsabilidade dos controladores:

16. No direito norte-americano, diferentemente dos administradores, o acionista controlador não está sujeito à obrigação de não competir com a companhia. Contudo, se o controlador usa sua posição como controlador para se aproveitar de uma oportunidade de negócio, impedindo a companhia de fazê-lo, ele terá violado o seu dever fiduciário para com a companhia. Neste último caso, o direito americano muito se assemelha ao brasileiro. $\mathrm{O}$ direito americano desenvolveu passos que o julgador deve considerar ao avaliar a ocorrência ou não da usurpação de uma oportunidade. (grifos nossos) ${ }^{83}$

A conclusão da Diretora Relatora pela absolvição dos acionistas controladores se deve, principalmente, a três fatores existentes quando da outorga de exclusividade na atividade de incorporação à LDI: (i) a CAL já não desempenhava a atividade de incorporação diretamente há três anos; (ii) o percentual de participação direta dos acionistas controladores da CAL na LDI era muito pequeno, não justificando uma condenação por usurpação de oportunidade comercial; e (iii) a situação financeira da CAL era delicada, o

\footnotetext{
${ }^{83}$ CVM, PAS CVM RJ2012/10487, Rel. Ana Dolores Moura Carneiro de Novaes, Rio de Janeiro, 5 nov. 2013.
} 
que justificava, naquele momento, a concentração na operação de construção, deixando a incorporação para ser explorada por outras sociedades ${ }^{84}$.

No julgamento dos recursos de ofício apresentados pela CVM a partir das absolvições dos acusados, o CRSFN manteve a decisão de $1^{\mathrm{a}}$ instância, concordando que:

[não teria] havido, por parte dos acionistas controladores da Construtora Adolpho Lindenberg, violação do dever fiduciário ou usurpação de oportunidade, porquanto ficou demonstrado que não havia a pretensão da companhia de exercê-la, estando já há mais de três anos fora da atividade de incorporação imobiliária e focada na de construção. ${ }^{85}$

Apesar de a solução do caso ter passado por argumentos muito mais práticos do que pela análise dos fundamentos legais aplicáveis à exploração de oportunidades comerciais por acionistas controladores, o Caso CAL abordou importante discussão sobre a abrangência do conceito de objeto social, que deve ser entendido como a atividade efetivamente exercida pela companhia, e não o conjunto de atividades - muitas vezes genérico - listado nos estatutos sociais de companhias abertas.

Independentemente da discussão sobre a abrangência do objeto social, verificou-se anteriormente que este não deve ser o critério para a definição

\footnotetext{
${ }^{84} \mathrm{O}$ raciocínio no caso concreto para estes três pontos pode ser extraído do seguinte trecho do voto da Diretora: "18. Inicialmente, é muito importante lembrar que, em 2006, quando da assinatura do acordo de exclusividade, a CAL não realizava atividades de incorporação diretamente há três anos e estava concentrando suas atividades na construção civil. Em 2011, a CAL retomou as atividades de incorporação, já sob o controle da LDI. 19. Observe-se que os controladores não criaram uma nova sociedade para explorar atividades de incorporação. Utilizaram a LDI, sociedade coligada na qual a CAL detinha uma participação de $25 \%$, a qual foi diluída com a entrada de novos sócios que subscreveram, sucessivamente, aumentos de capital na LDI. A compra pelos controladores da CAL de 2,7\% do capital da LDI com o aporte de cerca de R \$ 5 milhões até setembro/2007 não me parece suficiente, por si só, para caracterizar uma usurpação de oportunidade comercial, dado o pequeno percentual envolvido em relação à participação que os mesmos defendentes tinham na CAL. 20. Se, de fato, fosse viável a atividade de incorporação imobiliária diretamente pela CAL, não haveria incentivo econômico para que os seus acionistas passassem a exercê-la diretamente através da LDI para receber $2,7 \%$ do retorno desta atividade. Entendo que restou provado nos autos que a CAL estava em sérias dificuldades financeiras, em meados de 2006. De acordo com as demonstrações financeiras consolidadas de 2005, a CAL tinha obrigações de curto prazo com instituições financeiras e com a compra de terrenos de $\mathrm{R} \$ 30$ milhões, enquanto o seu caixa e as aplicações financeiras não passavam de R\$ 500 mil (fls. 148-165). Em 2005, o lucro antes dos impostos não passou de $\mathrm{R} \$ 250$ mil e a redução no capital circulante líquido no ano foi de $\mathrm{R}$ \$ 6,4 milhões. $\mathrm{O}$ prejuízo acumulado era de R \$ 4,4 milhões. Em suma, a situação da companhia era crítica".

${ }^{85}$ CRSFN, Recurso 13883, Rel. Haroldo Mavigner Guedes Alcoforado, Brasília, 19 abr. 2017.
} 
da oportunidade comercial como pertencente à companhia ou não. O titular da oportunidade é aquele que a desenvolveu ou aquele a quem a oportunidade foi oferecida.

Apesar de a acusação da CVM no Caso CAL ter imputado aos acionistas controladores responsabilidade pelo descumprimento de seu dever de lealdade constante no art. 116, parágrafo único, da LSA, o instituto da usurpação de oportunidade comercial não deveria ter sido o único viés analisado pelo Colegiado na apreciação do caso.

Compartilho da argumentação da Diretora Relatora no sentido que o interesse econômico dos acionistas controladores na LDI não era suficiente para justificar uma atuação propositalmente prejudicial à CAL para beneficiar aquela sociedade. Também concordo que a escolha pela concentração da companhia na atividade de construção foi uma decisão comercial razoável em razão da situação econômica vivida pela CAL à época dos fatos. Tanto foi assim que o voto da Diretora Relatora demonstra que "em julho de 2011, a Companhia [CAL] retomou as atividades de incorporação no mercado alvo".

Entretanto, situações como a do Caso CAL poderiam ensejar responsabilização dos acionistas controladores caso as situações fáticas do caso fossem diversas. A orientação dos acionistas controladores na diluição proposital da participação da CAL na LDI para beneficiá-los, de modo particular, em oportunidade que antes era desenvolvida pela CAL ou uma de suas controladas pode representar abuso do poder de controle, por infração ao dever de lealdade constante do art. 116, parágrafo único, da LSA.

Tal hipótese seria diferente da que está sendo tratada no presente estudo, uma vez que a oportunidade já estaria sendo desenvolvida pela companhia e os controladores, contra o interesse social, teriam decidido empenhar esforços, com consequências diretas para a companhia, para beneficiar a si mesmos de modo particular. 
Neste caso, estaríamos diante de uma oportunidade pertencente à companhia, tanto que era por ela explorada por meio de uma controlada, que lhe estaria sendo tolhida por decisão do acionista controlador, com prejuízo para o desenvolvimento do objeto social da companhia. O Caso CAL difere apenas (i) em razão do pequeno interesse econômico dos acionistas controladores na LDI; e (ii) da comprovação da dificuldade financeira da companhia, o que sustenta a decisão comercial de concentração na atividade de construção, abandonando a de incorporação. Como constatou-se que no Caso CAL as decisões foram tomadas no melhor interesse da companhia, não há de se falar em abuso do poder de controle.

\subsubsection{Caso Inepar (PAS CVM RJ2013/1840)}

O Caso Inepar também foi iniciado a partir de reclamação de investidor enviada à CVM:

Segundo a qual a Inepar Administração e Participações S.A ("IAP") estaria concorrendo com a Inepar S.A. Indústria e Construções ("IIC"), tendo em vista que ambas participavam simultaneamente das sociedades Companhia Brasileira de Diques ("CBD") e Triunfo Iesa Infraestrutura S.A. ("TIISA"). ${ }^{86}$

A companhia aberta sujeita à regulamentação da CVM era a IIC, cujo objeto social era o fornecimento de sistemas integrados, equipamentos e serviços para áreas de infraestrutura, óleo, gás, mineração, siderurgia e transporte metroviário. A IIC era majoritariamente controlada pela IAP, detentora de $57,21 \%$ das ações ordinárias da companhia e 22,15\% do capital total.

A alegação de usurpação de oportunidade comercial se deve ao fato de que em ambas as sociedades investidas, CBD e TIISA, era possível o investimento inicial inteiramente por parte da IIC, uma vez que as sociedades exerciam atividades condizentes com o objeto social da companhia aberta. No entanto, a IAP, acionista controladora da IIC, optou por realizar o

${ }^{86}$ CVM, PAS CVM RJ2013/1840, Rel. Ana Dolores Moura Carneiro de Novaes, Rio de Janeiro, 15 abr. 2014. 
investimento inicial na CBD (sem a participação da IIC) e na TIISA (em conjunto com a IIC, que aportou $30 \%$ do capital daquela sociedade), vendendo sua parcela em cada sociedade à IIC tempos depois.

Diante dos fatos apurados, a SEP entendeu pela existência de usurpação de oportunidade comercial por parte dos acionistas controladores da IIC, em infração ao disposto no art. 116, parágrafo único, da LSA.

Em resposta à acusação sobre eles formulada, os acionistas controladores apresentaram as seguintes justificativas, conforme relatado pela Diretora Ana Novaes:

As oportunidades de investimento na CBD e na TIISA teriam sido apresentadas à IAP e não à IIC. Desde as conversas iniciais entre os participantes dos respectivos grupos de investidores na CBD e na TIISA, teria sido esclarecido à IAP que a participação da IIC não deveria ser considerada diretamente nesses projetos dada sua "falta de crédito". No caso da TIISA, foi aceito pelos demais investidores que parcela significativa do investimento alocado à IAP (30\%) pudesse ser assumida pela IESA Projetos, Equipamentos e Montagens S.A. ("IESA Projetos"), subsidiária integral da IIC, uma vez que essa se encontrava em situação financeira mais consistente, dispondo de "crédito na praça". ${ }^{87}$

Entretanto, a Diretora Relatora Ana Novaes discordou dos argumentos da defesa, seguindo precedente iniciado no Caso M\&G Poliéster, segundo o qual " a situação financeira difícil não é motivo para que a oportunidade de negócio não seja oferecida à companhia".

Discorda-se desta interpretação. A situação financeira da companhia pode não ser, a priori, uma limitação à exploração de determinada oportunidade. Entretanto, pode ser que a utilização da companhia em difícil situação econômica como veículo de exploração da oportunidade não atenda aos interesses daquele que oferece a oportunidade, razão pela qual ele pode optar por recorrer diretamente aos acionistas controladores, que podem ter maior confiança do mercado e situação econômica mais equilibrada para arcar com os riscos da oportunidade.

${ }^{87}$ CVM, PAS CVM RJ2013/1840, Rel. Ana Dolores Moura Carneiro de Novaes, Rio de Janeiro, 15 abr. 2014. 
Mais uma vez a CVM, erroneamente, entendeu que o acionista controlador, por força do art. 116, parágrafo único, estaria obrigado a apresentar a oportunidade previamente à companhia e, apenas após a recusa da mesma, estaria livre para explorar a atividade diretamente ${ }^{88}$.

Considera-se que como a oportunidade foi diretamente oferecida ao acionista controlador, era ele pertencente, não havendo obrigação de prévio oferecimento à companhia.

O fato de as participações da IAP na TIISA e CBD terem sido, posteriormente, alienadas à IIC não muda em nada a situação do caso concreto. É certo que ambos os investimentos estavam inseridos no objeto social da IIC, o que não muda o fato de que a companhia não era a legítima detentora da oportunidade e apenas participou de uma delas por questões comerciais.

A IAP realizou investimentos iniciais que se mostraram bastante vantajosos na TIISA e CBD, tendo, em seguida, optado pela alienação de suas participações. Coube, então, aos administradores da IIC tomar a decisão sobre aumentar sua participação em ambos os investimentos ou não. Esta é a decisão que deve ser refletida e bem avaliada pelos administradores e, em caso de conflito de interesses ou realização em situações não equitativas, contestada pelos acionistas minoritários da companhia.

\footnotetext{
${ }^{88}$ Neste sentido está o voto da Diretora Relatora Ana Novaes: "13. Mais grave ainda é que não consta dos autos nenhuma discussão a respeito do assunto entre a IIC e o seu acionista controlador, a IAP. Os acionistas controladores ao deterem o comando da companhia e a maioria absoluta dos votos no conselho de administração de sua controlada (no caso, da IIC), podem fazer prevalecer interesses próprios e individuais em detrimento dos interesses da companhia, em infração ao parágrafo único do art. 116 da lei $\mathrm{n}^{\circ} 6.404 / 1976$. 14. Não deve prosperar o argumento da defesa de que as oportunidades de negócio na CBD e na TIISA foram oferecidas à IAP e não à IIC. Os controladores deveriam ter encaminhado a oportunidade à IIC ou direcionado o ofertante à IIC, tão logo tenham constatado que o investimento oferecido relacionava-se com o objeto social da IIC. Só após uma detalhada e fundamentada decisão da IIC, rejeitando a oportunidade comercial, observado o interesse desta em realizar o seu objeto social, é que os controladores poderiam vir a reter tal oportunidade de negócio que, a priori, caberia no objeto social da companhia controlada. Para tanto, deveriam constar dos autos elementos que permitissem uma decisão informada e refletida por parte da IIC. Em nenhum momento restou demonstrado nos autos que a IIC tenha manifestado falta de interesse em investir diretamente na CBD e na TIISA ou ainda que não tivesse condições financeiras para tal. Aliás, nenhuma análise neste sentido foi acostada nos autos.”
} 
Mais uma vez não se enxerga ilegalidade na utilização da oportunidade pelos acionistas controladores, apesar de o colegiado da CVM ter sido unânime na condenação dos mesmos.

Não obstante, o CRFN julgou, em 27 de setembro de $2016^{89}$, os recursos apresentados pelos acionistas controladores da IIC, decidindo pela manutenção da condenação e reiterando a maior parte dos fundamentos apresentados pela CVM com relação à usurpação de oportunidade comercial.

\subsection{Repressão por meio de Processos Administrativos Sancionadores}

Da análise dos quatro casos da CVM que trataram do aproveitamento de oportunidades comerciais por parte de acionistas controladores de companhia aberta percebe-se que apenas um foi discutido no âmbito de um processo administrativo não-sancionador - o Caso AMBEV. Naquele caso a CVM se viu pela primeira vez diante de uma alegação de usurpação de oportunidade comercial por acionista controlador, ainda que naquela hipótese os controladores fossem também administradores da companhia.

No Capítulo 1, foi estudado o regime de responsabilidade dos acionistas controladores, com a conclusão de que não existe qualquer previsão expressa na LSA ou nos dispositivos regulamentares editados pela CVM que proíba o acionista controlador de utilizar diretamente uma oportunidade que tenha sido a ele ofertada, ainda que tal oportunidade pudesse ser explorada pela companhia da qual é controlador.

A corrente doutrinária e jurisprudencial brasileira que defende a possibilidade de responsabilização de acionistas controladores por usurpação de oportunidade comercial, o faz traçando paralelo entre o dever de lealdade presente no art. 116, parágrafo único, e o art. 155, inciso I, ambos da LSA. Para os que defendem esta posição, acionistas controladores no Brasil estão sujeitos ao mesmo dever de lealdade dos administradores em razão da

\footnotetext{
${ }^{89}$ Julgamento do Recurso 14047, de relatoria da Conselheira Ana Paula Zanetti de Barros Moreira, realizado na $395^{\mathrm{a}}$ sessão de julgamento do CRSFN, realizada no dia 27 de setembro de 2016.
} 
posição de destaque que ocupam se comparado a outros mercados mais desenvolvidos.

Independentemente da posição que se adote, fato é que a questão não é simples e não foi expressamente abordada pela LSA. É justamente nessas zonas de penumbra que a atuação da CVM, como órgão regulador do mercado de capitais, se torna mais sensível.

A CVM atua com o propósito de promover o "equilíbrio entre a iniciativa dos agentes e a efetiva proteção dos investidores" ${ }^{\prime 90}$. Para atingir tal finalidade, é fundamental que as decisões da autarquia garantam efetiva orientação e previsibilidade aos agentes de mercado. É com este intuito que foi criado o princípio da vedação à aplicação retroativa de nova interpretação em processos sancionadores.

\subsubsection{Vedação à aplicação retroativa de nova interpretação em processos sancionadores}

Talvez um dos maiores princípios para o alcance de um mercado de capitais robusto e desenvolvido seja o da segurança jurídica. Agentes econômicos de todas as áreas do mercado de capitais precisam estabelecer previsibilidade nos tipos de conduta que estão autorizados ou vedados a praticar para que possam orientar as suas decisões sem o medo de serem repreendidos pela regulação estatal.

Comentando a segurança jurídica como princípio aplicável ao Direito Administrativo Sancionador Alexandre Pinheiro dos Santos, Fábio Medina Osório e Julya Sotto Mayor afirmam:

Reside nos arts. $5^{\circ}$, XXXVI, da CF, e $2^{\circ}$ da Lei n. 9.784 , de 29 de janeiro de 1.999 , previsão expressa acerca da segurança jurídica como princípio normativo vinculante. Uma série de institutos é informada e influenciada pelo valor da segurança jurídica. Cuida-se, no plano axiológico, de projetar efeitos legislativos,

90 Propósito divulgado pela CVM em seu website. Disponível em: <http://www.cvm.gov.br/menu/acesso informacao/institucional/sobre/cvm.html > Acesso em: 07 nov. 2017. 
administrativos e jurisprudenciais. Todo o ideário do Estado de Direito é calcado no valor da segurança jurídica, eis que se trata de um dos pilares da juridicidade moderna. Não impressiona, pois, que tal princípio seja a pedra de toque da hermenêutica contemporânea, sobretudo da hermenêutica vinculada ao campo punitivo, comprometendo-se com liberdades individuais e previsibilidade mínima das proibições estatais..$^{91}$ (grifos nossos)

A falta de segurança jurídica ainda é um dos principais fatores de risco que limitam o mercado de capitais brasileiro, tendo reflexos nos fatores de risco das principais companhias abertas brasileiras. A título exemplificativo, o Formulário de Referência de 2016 da CVC Brasil Operadora e Agência de Viagens S/A possuía a seguinte descrição na sessão fatores de risco:

Mudanças nas leis e regulamentações relacionadas a nós bem como à alteração da regulação tributária podem nos afetar adversamente.

A promulgação e/ou mudanças de leis e regulamentações aplicáveis aos nossos negócios, bem como a mudança da interpretação por parte do sistema judiciário brasileiro e de órgãos da administração pública podem impactar negativamente a nossa situação financeira." (grifos nossos) ${ }^{92}$

Talvez o maior termômetro da segurança jurídica no mercado de capitais sejam as decisões de processos administrativos julgados pela CVM. Certamente, as decisões do Colegiado da autarquia abrem precedentes que influenciarão a forma de agir dos agentes de mercado, a fim de evitar sanções da CVM.

O problema está quando a sanção aplicada pela autarquia carece de previsibilidade, ou seja, quando a CVM utiliza o mecanismo de processo administrativo sancionador para passar uma "mensagem" ao mercado a respeito da interpretação de determinada prática que nunca havia sido analisada pelo órgão regulador antes, ou que vinha sendo interpretada de forma diversa.

\footnotetext{
${ }^{91}$ SANTOS, Alexandre Pinheiro dos. OSÓRIO, Fábio Medina. WELLISCH, Julya Sotto Mayor. Mercado de Capitais - Regime Sancionador. São Paulo: Saraiva, 2012. pp. 58 e 59.

${ }^{92}$ Trecho extraído da Seção 4 - Fatores de Risco do Formulário de Referência - 2016 - CVC BRASIL OPERADORA E AGÊNCIA DE VIAGENS S/A. Disponível em: $<$ http://sistemas.cvm.gov.br/> Acesso em: 07 nov. 2017.
} 
É para garantir previsibilidade às decisões e segurança jurídica ao mercado que se defende o princípio da vedação à aplicação retroativa de nova interpretação em processos administrativos sancionadores, previsto no art. $2^{\circ}$, inciso XIII da Lei $\mathrm{n}^{\circ}$ 9.784, de 29 de janeiro de 1999, que regula o processo administrativo no âmbito da administração pública federal ${ }^{93}$.

A CVM já teve a oportunidade de se manifestar sobre a extensão da vedação à aplicação retroativa de nova interpretação e reconheceu a impossibilidade de imposição de sanção disciplinar na falta de orientação prévia da autarquia sobre o tema em exame, conforme se extrai das palavras do ex-Diretor Luiz Antonio de Sampaio Campos:

\begin{abstract}
A extensão que dou a esse dispositivo [art. $2^{\circ}$, inciso XIII da Lei ${ }^{\circ}$ 9.784], naturalmente, é que os atos praticados à luz da decisão ou da orientação administrativa vigente não devem - pelo menos do ponto de vista do processo disciplinar, aqui eu enfatizo - ser tidos como merecedores de sanção disciplinar, por conta de uma nova orientação que sobreveio após a prática dos atos. A segurança jurídica e a estabilidade das relações jurídicas são valores que merecem atenta proteção e vêm sendo perseguidos sistematicamente pela sociedade, num esforço incessante dos legisladores e juristas.
\end{abstract}

\title{
$[\ldots]$
}

Mas o fato, com o qual temos que conviver, ao menos juridicamente, gostemos ou não, é que não havia essa orientação anterior. Assim, entendo que, antes da mudança da orientação, a companhia agiu, no meu modo de ver muito razoavelmente, confiando num entendimento de que, como o Colegiado e a própria área técnica silenciaram sobre o mérito da forma de cálculo do dividendo, após ela ter sido questionada e apresentado os esclarecimentos, a CVM encontrou satisfação naqueles esclarecimentos que prestou, inclusive com pareceres. Pareceres esses que, salvo engano, foram juntados na ocasião. ${ }^{94}$ (grifos nossos)

Um processo sancionador ou disciplinar não pode ser um fórum para a discussão da regulação do mercado de capitais; muito pelo contrário, ele

\footnotetext{
93 “Art. 2o A Administração Pública obedecerá, dentre outros, aos princípios da legalidade, finalidade, motivação, razoabilidade, proporcionalidade, moralidade, ampla defesa, contraditório, segurança jurídica, interesse público e eficiência. [...] XIII - interpretação da norma administrativa da forma que melhor garanta o atendimento do fim público a que se dirige, vedada aplicação retroativa de nova interpretação." Disponível em: <http://www.planalto.gov.br/ccivil_03/leis/L9784.htm> Acesso em: 07 nov. 2017.

${ }^{94}$ CVM. PAS TA No RJ2002/1846, Rel. Eli Loria, Rio de Janeiro, 14 Jul. 2004.
} 
dever ser o ambiente aonde se reprimem as práticas que vão de encontro ao que já é exigido pela regulação.

Neste sentido, o ex-presidente da CVM, Marcelo Trindade, assim se posiciona sobre o assunto:

Para essa modalidade de normas abertas, que permitem variada interpretação, o processo sancionador não se presta a ser o veículo utilizado pela CVM para a disseminação de novos entendimentos ou a alteração de postura da autarquia quanto a práticas até então adotadas pelos agentes de mercado.

Nesses casos a CVM deve utilizar outros mecanismos que estão à sua disposição para orientar o mercado, ao invés de utilizar a imposição de sanção sobre um particular para fazê-lo.

A sanha pela punição e os holofotes que ela gera constituem permanente e perigosa tentação que o regulador deve evitar. Mas é o uso combinado dos poderes conferidos à CVM, de maneira equilibrada e com a ponderação das situações a que cada um deles melhor se adapta, que será mais eficiente para o mercado e mais justo para os regulados. ${ }^{95}$ (grifos nossos)

No caso da usurpação de oportunidade comercial por acionista controlador, a CVM desrespeitou tal princípio.

Como vimos, o primeiro caso julgado pela autarquia a respeito do assunto foi o caso $\mathrm{AMBEV}$, discutido no âmbito de um processo não sancionador, originado de recurso contra a decisão da SEP que não havia identificado indícios de irregularidade capazes de instaurar um processo sancionador. Portanto, à época, a própria SEP não reconhecia a possibilidade de usurpação pelo acionista controlador, ainda que naquele caso os controladores também fossem administradores, e foi acompanhada pelo Colegiado da CVM.

Na segunda oportunidade que teve para analisar o tema, a SEP mudou seu posicionamento e decidiu instaurar processo sancionador contra a acionista controladora da M\&G Poliéster por suposta usurpação de

95 TRINDADE, Marcelo. Processo Sancionador na CVM: Limites e Possibilidades. In: VENANCIO FILHO, Alberto; LOBO, Carlos Augusto da Silveira; ROSMAN, Luiz Alberto Colonna (orgs.). Lei das S.A. em seus 40 anos. $1^{\text {a }}$ ed. Rio de Janeiro: Forense, 2017, p. 499. 
oportunidade comercial. Contrariando o único caso em que a CVM havia discutido o assunto, o Colegiado decidiu pela condenação da controladora ao pagamento de multa no valor de $\mathrm{R} \$ 45.768 .546,06$ (quarenta e cinco milhões, setecentos e sessenta e oito mil, quinhentos e quarenta e seis reais e seis centavos).

No julgamento do Caso M\&G Poliéster a CVM não só revisitou o posicionamento por ela adotado anteriormente, como foi a primeira vez em que reconheceu a possibilidade de usurpação de oportunidade comercial por acionista controlador. Logo na primeira vez em que chegou a tal entendimento, aplicou uma das maiores multas de sua história.

Flagrante, portanto, notar a quebra da segurança jurídica dos agentes do mercado com a falta de previsibilidade desta decisão, tomada sem qualquer indicativo anterior ao mercado de que a prática de utilização de oportunidade comercial por acionista controlador seria considerada irregular pela CVM. 


\section{CAPÍTULO 4 - O MELHOR TRATAMENTO DA EXPLORAÇÃO DE OPORTUNIDADE PELO ACIONISTA CONTROLADOR - ASPECTOS PRÁTICOS}

\subsection{Inviabilização de modelos de negócio e o desestímulo à abertura de capital}

Resta, neste ponto, talvez a maior preocupação e espectro sobre o qual foi pautado todo o estudo e elaboração do presente trabalho.

As consequências práticas da interpretação até o momento preponderante na doutrina e jurisprudência nacional acerca da utilização de oportunidades comerciais por acionista controlador são prejudiciais à livre iniciativa e, principalmente, ao melhor desenvolvimento do mercado de capitais brasileiro.

Entender que o acionista controlador está sujeito aos mesmos padrões de lealdade impostos aos administradores de companhias e que, portanto, estaria impedido de usar diretamente as oportunidades comerciais que tivesse conhecimento e que se relacionassem à atividade da companhia, significaria a inviabilização de determinados modelos de negócio e, consequentemente, o desestímulo à abertura de capital por determinados setores da economia.

\subsubsection{Indústria de private equity e venture capital}

O mercado de capitais vem se desenvolvendo de tal forma que algumas estruturas de investimento exigem que haja investimento em mais de uma empresa do mesmo setor. Como exemplo mais claro disso estão os Fundos de Investimento em Participações (FIPs) voltados para investimento em empresas do ramo tecnológico.

O setor de tecnologia é tão dinâmico que a todo momento surgem novos projetos e novas start-ups com ideias que prometem revolucionar produtos de sucesso já existentes. Tais empresas, ainda em estágio 
embrionário e com projetos incipientes (os chamados projetos greenfield), necessitam de um "empurrão inicial”, o que fez crescer ao redor do mundo as figuras do investidor-anjo e da indústria de venture capital $^{96}$.

No Brasil, o principal veículo de investimentos utilizado pela indústria de private equity/venture capital é o Fundo de Investimento em Participações, cuja regulação foi recentemente modificada pela Instrução CVM n' 578, de 30 de agosto de 2016 ("ICVM 578”). Os FIPs permitem a reunião dos recursos de diversos investidores, que serão geridos por um gestor profissional para alocação em empresas - muitas vezes em estágio inicial - com um grande potencial de crescimento.

O modelo é excelente para as start-ups do setor tecnológico, que buscam investidores que acreditam no seu projeto para entrarem como sócios do empreendimento e assumirem gestão ativa dos negócios para desenvolver o projeto pensado por estes empreendedores.

Justamente por investirem em projetos greenfield, cercados de riscos e incertezas, é que os gestores destes FIPs procuram diversificar a sua carteira de investimento. Em estudo desenvolvido pelo Insper, em parceria com a Spectra Investimentos, que analisou centenas de transações de private equity e venture capital realizadas entre 1982 a 2014 no Brasil, constatou-se que a taxa média de retorno médio sobre o investimento em private equity foi de $34 \%$, e que " $39,1 \%$ das transações de venture capital e 14,8\% das de private equity tiveram um múltiplo do capital investido igual a zero, ou seja, com desempenho fraco ou até com prejuízo" 97 . Entretanto, quando estes

\footnotetext{
${ }^{96}$ Conforme explicação constante do website da Associação Brasileira de Private Equity e Venture Capital - ABVCAP, "Enquanto o venture capital está relacionado a empreendimentos em fase inicial, o private equity está ligado a empresas mais maduras, em fase de reestruturação, consolidação e/ou expansão de seus negócios. A essência do investimento está em compartilhar os riscos do negócio, selando uma união de esforços entre gestores e investidores para agregar valor à empresa investida. Os investimentos podem ser direcionados para qualquer setor que tenha perspectiva de grande crescimento e rentabilidade ao longo prazo, de acordo com o foco de investimentos definido pelos investidores ou fundos". Disponível em: <http://www.abvcap.com.br/industria-de-pe-vc/sobre-o-setor.aspx?c=pt-br>. Acesso em: 07 nov. 2017.

${ }^{97}$ Dados do estudo foram reportados em notícia publicada em 10 de novembro de 2014 pelo portal "Investidor Institucional". Disponível em:
} 
investimentos se mostram realmente inovadores e se tornam um sucesso, os ganhos potenciais para o FIP são gigantescos.

O mecanismo de entrada dos FIPs como investidores destas start-ups varia de caso a caso. Geralmente, procura-se garantir que os sócios fundadores - conhecedores do produto que se está desenvolvendo - se mantenham à frente da administração da companhia, ficando apenas a parte financeira a cargo dos gestores do FIP investidor. O percentual adquirido no investimento inicial do FIP também pode variar de forma significativa, havendo situações em que o FIP prefere adquirir apenas o necessário para ter certa discricionariedade na administração ativa da empresa ou situações em que ele adquire o controle das start-ups.

Além disso, os gestores especializados na indústria de private equity costumam estruturar diversos veículos de investimento, cada um com características próprias como: margem de risco compatível com o público alvo do fundo, maior ou menor prazo de retorno do investimento, taxas de gestão variando conforme a performance do fundo e tipo de ativo alvo. A gestão de diversas carteiras de FIP pelo mesmo gestor, o que é muito comum no mercado brasileiro, amplia ainda mais a possibilidade de que os veículos realizem investimentos em empresas concorrentes, podendo se tornar controladores de duas companhias do mesmo setor ${ }^{98}$.

Por isso, é normal que os FIPs voltados à investimentos de venture capital apenas no setor de tecnologia, por exemplo, sejam controladores de mais de uma empresa do setor, muitas vezes até concorrentes entre si. Caso o projeto de ambas as empresas vá para a frente, estaremos diante de situações em que duas empresas concorrentes, controladas pelo mesmo FIP,

$<$ http://www.investidorinstitucional.com.br/index.php/br/investidoronline/12780-

ind $\%$ C3\%BAstria-de-pe-e-vc-demonstra-amadurecimento-nos-\%C3\%BAltimos-30-anos.html>. Acesso em: 07 nov. 2017.

${ }^{98}$ Segundo estudo realizado pela KPMG, em conjunto com a ABVCAP, "ainda existe grande concentração de capital sob gestão das grandes firmas de Private Equity que atuam no país". Os dados levantados demonstram que, em 31 de dezembro de 2015, 67,1\% do total do capital investido na indústria no Brasil estavam nas mãos dos 10 maiores gestores do país. Disponível em <http://www.abvcap.com.br/Download/Estudos/3484.pdf $>$ Acesso em: 07 nov. 2017. 
abrirão capital e terão sobre elas a incidência da regulação e fiscalização da CVM.

Considerando a necessidade de alguns FIPs na diversificação de suas carteiras, como devem agir os seus gestores e administradores de FIP quando forem gestores de veículos controladores de mais de uma companhia aberta do mesmo setor? Certamente, se entender que as oportunidades comerciais recebidas pelos acionistas controladores devem, obrigatoriamente, ser oferecidas às companhias, este gestor estará diante de uma "escolha de Sofia", sendo responsabilizado por qualquer oportunidade que decida explorar por meio de uma ou outra companhia, na medida em que terá "usurpado" a oportunidade da companhia que não a recebeu.

Mais uma vez percebe-se que não há limitação no ordenamento jurídico brasileiro para o controle de duas empresas do mesmo setor e, potencialmente, concorrentes. Está dentro da liberdade de iniciativa do acionista controlador decidir sobre a forma de aproveitamento das oportunidades a ele oferecidas, sob pena de inviabilização das indústrias de private equity e venture capital brasileiras.

\subsubsection{Controle de riscos pelo acionista controlador}

Outra situação já existente no mercado de capitais brasileiro e que pode ser extremamente prejudicada com a interpretação que vem prevalecendo para a responsabilização de acionistas controladores pela usurpação de oportunidades comerciais, é a alocação de riscos em empresas já consolidadas no mercado.

Alguns modelos de negócio brownfield - empresas com estrutura pronta e projeto consolidado no mercado - não admitem a tomada de grandes riscos que podem prejudicar a saúde financeira da companhia.

Cita-se, como exemplo, o caso da antiga Tractebel Energia S.A., hoje Engie Brasil Energia S.A. (“Companhia”), cujo objeto social é a construção e operação de usinas produtoras de energia elétrica. O último o Formulário 
de Referência divulgado pela companhia em 06 de outubro de 2017 apresentava a descrição do seguinte fator de risco:

\section{Os interesses de nosso Acionista Controlador podem ser conflitantes com os interesses de nossos investidores.}

O Acionista Controlador tem poderes para, entre outras coisas, eleger a maioria dos membros do Conselho de Administração e determinar o resultado de deliberações que exijam aprovação de acionistas, inclusive em operações com partes relacionadas, reorganizações societárias, alienações de ativos, parcerias e pagamento de quaisquer dividendos futuros, observadas as exigências de pagamento do dividendo obrigatório, impostas pela Lei das Sociedades por Ações e pelo Estatuto Social da Companhia. O Acionista Controlador poderá ter interesse em realizar aquisições, alienações de ativos, parcerias, na obtenção de financiamentos ou operações similares que podem ser conflitantes com os interesses dos investidores e causar um efeito material adverso para a Companhia. ${ }^{99}$ (grifos nossos)

Este fator de risco vem sendo repetido no Formulário de Referência da Companhia ao longo dos anos, e é fruto de uma estratégia adotada pela sua controladora indireta, a companhia francesa GDF SUEZ. A GDF SUEZ mantém participação em diversas usinas de interesse da Companhia, realizando o que se chamou de "modelo de transferência":

"GDF SUEZ participa dos leilões e desenvolve os projetos hidrelétricos, mitiga os principais riscos, e então transfere os projetos para a Tractebel Energia.

O momento da transferência é determinado pelo contexto e perfil de risco de cada projeto." ${ }^{100}$ (grifos nossos)

Em apresentação aos acionistas para o Business Day da Companhia realizado em $01.10 .2010^{101}$, o grupo controlador explicou os ganhos de sinergia do "modelo de transferência":

\footnotetext{
${ }^{99}$ Trecho extraído da $7^{\text {a }}$ Versão do Formulário de Referência de 2017 da Companhia, p. 24.

100 Trecho extraído de apresentação aos acionistas realizada em 01.10.2010, disponível em: http://www.tractebelenergia.com.br/wps/wcm/connect/15060b90-8f30-4d06-8e0dea97b45b9128/115018.pdf?MOD=AJPERES\&CACHEID=ROOTWORKSPACE15060b90-8f304d06-8e0d-ea97b45b9128.

${ }^{101}$ Slide extraído da apresentação aos acionistas da Tractebel, realizada em 01.10.2010. Disponível em: $\quad<\mathrm{http}: / / \mathrm{www}$. tractebelenergia.com.br/wps/wcm/connect/15060b90-8f30-4d06-8e0dea97b45b9128/115018.pdf?MOD=AJPERES\&CACHEID=ROOTWORKSPACE15060b90-8f304d06-8e0d-ea97b45b9128> Acesso em: 07 nov. 2017.
} 


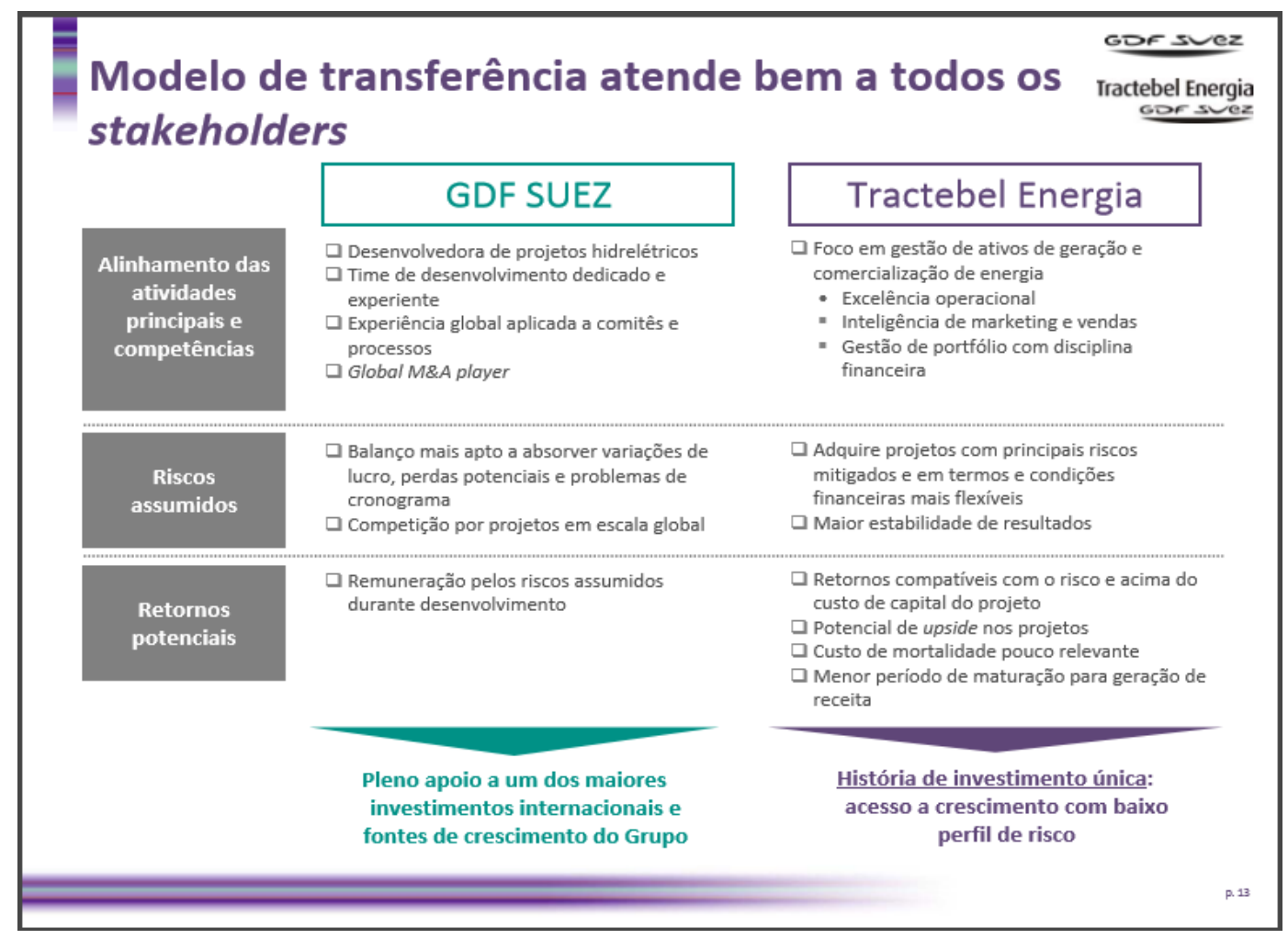

$\mathrm{Na}$ mesma apresentação a Companhia demonstrou que o grupo controlador absorveu os custos de análise e desenvolvimento de aproximadamente 15 (quinze) projetos que não foram transferidos para a Tractebel Energia ${ }^{102}$, evidenciando o risco da operação que estava sendo mitigado. A prática da acionista controladora vinha, inclusive, sendo mencionada nos relatórios das agências classificadoras de rating como positiva para os negócios da Tractebel ${ }^{103}$.

\footnotetext{
${ }^{102}$ Os projetos descontinuados listados pela apresentação são: (i) Hidrelétricos - Santa Isabel (1.087 MW); Peixe (452 MW); Serra do Facão (210 MW); Pedra do Cavalo (160 MW); Couto Magalhães (150 MW); Simplício (323 MW); Baguari (140 MW); Baixo Iguaçu (350 MW); Dardanelos (261 MW); Belo Monte (11.233 MW); Inambari (Peru -1.355 MW); Santo Antonio (3.150 MW); Colider (300 MW); e (ii) Termelétricos - Piratininga; TCN; Três Lagoas; Uruguaiana; Eletrobolt/Rio Gen; e Termogaúcha.

${ }^{103} \mathrm{Na}$ apresentação aos acionistas realizada em 01.10.2010, a Companhia e os acionistas controladores transcrevem os seguintes trechos dos relatórios de rating: (i) Relatório da Fitch Ratings de 28.07.2010: "Apesar da existência do risco inerente à construção das plantas, a Fitch vê como positiva a prática do Grupo GDF SUEZ de desenvolver os projetos e transferi-los para a Tractebel apenas após a mitigação dos principais riscos..."; e (ii) Relatório da Standard \& Poor's de 21.07.2010: "Acreditamos que, em função de crescente importância estratégica da Tractebel Energia S.A. no portfólio de ativos da GDF SUEZ, o suporte de sua controladora tem se tornado mais evidente. Tal suporte tem se provado na forma como a GDF SUEZ tem transferido ativos de geração relevantes, mitigando riscos de projeto."
} 
Até hoje a Companhia mantém a prática de sempre divulgar comunicações ao mercado a respeito de negócios com partes relacionadas que impliquem aumento de participação, venda ou aquisição de alguma usina que se relaciona com o objeto social da Companhia ${ }^{104}$.

O último fato relevante divulgado pela Companhia a respeito de uma das aquisições de sua controladora indireta explica a razão de ser deste modelo de negócios. Naquela oportunidade, a GDF SUEZ firmou joint venture com a Camargo Correa para a construção da usina, tendo sido acordado que a construtora deixaria sua participação do projeto "durante as últimas fases da sua construção, uma vez que os principais riscos de construção houvessem sido mitigados "105.

Percebe-se, portanto, que uma das fases dos projetos desenvolvidos pela Companhia, a fase de construção, engloba uma exposição muito grande à risco, sem nenhum retorno financeiro. Diante de tal cenário, a controladora adquire participações nos projetos greenfield (ainda incipientes e em fase de construção) para depois transferi-los à Companhia, com um projeto maduro e livre dos principais riscos da operação. O Formulário de Referência da Companhia também apresenta o "modelo de transferência" como diferencial da Companhia:

\begin{abstract}
A Companhia beneficia-se igualmente das sinergias geradas entre as demais empresas do Grupo ENGIE. Tanto o processo de expansão quanto a inserção em novos mercados estratégicos estão amparados na sólida estrutura organizacional e financeira do Grupo e na larga experiência internacional de seus administradores. ${ }^{106}$
\end{abstract}

Logicamente, este modelo de negócios pressupõe que a Companhia entre em diversos contratos com partes relacionadas, o que exigirá maior

\footnotetext{
104 A título exemplificativo podemos mencionar: Fato Relevante divulgado em 01.10.2012, a respeito da aquisição de participação na Usina Hidrelétrica de Jirau e Fato Relevante divulgado em 15 de maio de 2007 sobre a aquisição da Companhia Energética São Salvador de um de seus controladores.

${ }^{105}$ Trecho extraído do Fato Relevante divulgado pela Companhia em 01.10.2012, a respeito da aquisição de participação na Usina Hidrelétrica de Jirau.

${ }^{106}$ Trecho extraído da $7^{\mathrm{a}}$ Versão do Formulário de Referência de 2017 da Companhia, p. 110.
} 
controle dos órgãos da administração e dos próprios acionistas nas matérias que sejam levadas à Assembleia.

Para assegurar que as transações com partes relacionadas "observem sempre condições estritamente comutativas, negociadas de forma independente, mediante processo transparente e seguro" ${ }^{107}$, a Companhia conta com um Comitê Especial Independente para Transações com Partes Relacionadas, formado exclusivamente por administradores da Companhia e instalado sempre que haja pretensão de celebração de qualquer negócio ou transação com parte relacionada da Companhia.

O modelo da Tractebel é apenas um exemplo de situação no mundo real em que a atuação do acionista controlador é elemento essencial na mitigação dos riscos da companhia por ele controlada, o que justifica sua utilização de oportunidades comerciais incipientes, nos chamados projetos greenfield, até que o empreendimento tenha maturidade e segurança suficientes para a entrada da Companhia.

Mais uma vez, se entende que os controladores não podem utilizar-se das oportunidades a eles oferecidas estaremos limitando e até inviabilizando que companhias com o modelo de negócios da Tractebel tenham capital aberto e acesso à poupança popular, o que certamente não é medida saudável para o mercado de capitais brasileiro.

\subsection{Disclosure de informações}

Por mais simples que pareça, a solução para a proteção dos acionistas minoritários contra o aproveitamento de oportunidades comerciais por acionistas controladores parece estar na ampla e correta divulgação de informação ao mercado.

Naturalmente, esta é uma proposta que vai de encontro à cultura protecionista da legislação brasileira, que nos leva a crer que quanto maior o

\footnotetext{
${ }^{107}$ Descrição presente na $7^{\text {a }}$ Versão do Formulário de Referência de 2017 da Companhia, p. 238.
} 
número de regras de conduta existentes, maior a proteção aos agentes integrantes de determinado ambiente.

Em diversos ramos do Direito e da Economia tal afirmação pode ter algum fundo de verdade, principalmente quando se considera a assimetria das partes integrantes de determinada relação jurídica. Os maiores exemplos são as relações de trabalho e de consumo. Entretanto, no mercado de capitais esta afirmação não se sustenta.

A hipossuficiência no mercado de capitais, nos poucos casos em que é verificada, não justifica o protecionismo exacerbado que enxergamos em outros ramos do Direito.

$\mathrm{O}$ investimento em mercado de capitais, especialmente no investimento direto em ações de companhias abertas é, por natureza, arriscado. Dentre as possibilidades de investimentos existentes na Economia, diversos são os produtos que garantem retorno seguro com baixo risco. $\mathrm{O}$ mercado de ações não é um deles.

Justamente por apresentarem maiores riscos, os investimentos em ações possibilitam maiores retornos aos que decidem empenhar seus recursos em companhias abertas.

Certamente, estes investidores minoritários, que apostaram no negócio desenvolvido por uma determinada companhia, confiam que os acionistas controladores estão empenhados na maximização dos lucros advindos daquela atividade.

Também é lógico que, ao terem notícia de oportunidades comerciais que seriam passíveis de aproveitamento pela companhia, muitos acionistas minoritários demonstrem interesse em fazer parte e receber os resultados daquele negócio. Acontece que a oportunidade comercial que é ofertada diretamente ao acionista controlador não pertence à companhia, o que pode frustrar os interesses destes minoritários. 
O potencial lesivo deste desalinhamento de interesses não está, entretanto, na repressão da utilização legítima da oportunidade por parte do controlador, mas no desalinhamento informacional que pode ocorrer caso a situação não seja amplamente divulgada ao mercado.

A notícia de que o acionista controlador, com poderes para ditar o norte do desenvolvimento das atividades da sociedade em que determinado agente possui recursos investidos, está explorando diretamente oportunidades a ele apresentadas, certamente é uma informação que impacta na decisão de investimento dos agentes de mercado.

Sendo assim, tal informação preenche o requisito para ser caracterizada como fato relevante, à luz do art. $2^{\circ}$, inciso II da Instrução CVM $n^{\circ} 358$, de 3 de janeiro de 2002 (“ICVM 358”) 108.

Ao receberem tal informação, muitos investidores duvidarão da capacidade daquela companhia em se manter lucrativa com um controlador que explora diretamente atividades correlatas às da companhia, enquanto outros enxergarão aquela informação como positiva para os negócios (como de fato o é em exemplos como o da Tractebel, descritos no item 4.2.2 acima).

De um modo ou de outro, o recebimento da informação pelo mercado impactará na cotação daquelas ações no mercado, o que poderá ser prejudicial ou não para futuras captações da companhia e para seus negócios.

Vale ressaltar que o acionista controlador, neste caso detentor da informação relevante que deverá ser divulgada ao mercado, está obrigado a informar ao Diretor de Relações com Investidores qualquer ato ou fato relevante de que tenha conhecimento, por força do art. $3^{\circ}, \S 1^{\circ}$ da ICVM

\footnotetext{
108 "Art. $2^{\circ}$ : Considera-se relevante, para os efeitos desta Instrução, qualquer decisão de acionista controlador, deliberação da assembléia geral ou dos órgãos de administração da companhia aberta, ou qualquer outro ato ou fato de caráter político-administrativo, técnico, negocial ou econômicofinanceiro ocorrido ou relacionado aos seus negócios que possa influir de modo ponderável: $[\ldots]$

II - na decisão dos investidores de comprar, vender ou manter aqueles valores mobiliários;" (Disponível em: <http://www.cvm.gov.br/legislacao/instrucoes/inst358.html > Acesso em: 07 nov. 2017.)
} 
$358^{109}$. Caso não o faça, estará sujeito à responsabilização por meio de processo administrativo sancionador na CVM.

Por certo também que quando a utilização de oportunidade comercial por acionista controlador estiver inserida no modelo de negócios da companhia - ou seja, quando ocorrer de forma constante e frequente - a divulgação desta informação também deverá ser mencionada nos prospectos de distribuição de quaisquer valores mobiliários emitidos pela companhia controlada, assim como em seus Formulários de Referência, especialmente na seção de fatores de risco.

Mais uma vez cita-se o exemplo da Tractebel como modelo de companhia que utilizou a mitigação de riscos por seu acionista controlador e teve na autorregulação uma excelente oportunidade de desenvolvimento de sua governança corporativa interna.

Logo após o anúncio de transferência de um dos projetos hidrelétricos detidos pela acionista controladora para a Tractebel, a companhia recebeu algumas preocupações e receios dos seus acionistas minoritários, as quais serviram de base para a melhora do modelo de governança para operações com partes relacionadas da companhia.

Basicamente, os acionistas minoritários reconheciam que "a lógica do modelo de transferência é sólida e elemento-chave para a estratégia de crescimento" da Tractebel, mas reclamavam (i) da "baixa previsibilidade $e$ transparência do processo e preço de transferência", (ii) da "falta de informação sobre projetos em desenvolvimento"; e (iii) do "processo de governança em transações com controlador". Para endereçar estes pontos, a Companhia e os acionistas controladores anunciaram a formação de um Comitê Independente para analisar as operações com partes relacionadas dentro da Companhia e a criação de uma equipe de comunicação da

\footnotetext{
109 “Art. $3^{\circ}$ [...] §1o Os acionistas controladores, diretores, membros do conselho de administração, do conselho fiscal e de quaisquer órgãos com funções técnicas ou consultivas, criados por disposição estatutária, deverão comunicar qualquer ato ou fato relevante de que tenham conhecimento ao Diretor de Relações com Investidores, que promoverá sua divulgação." (Disponível em: <http://www.cvm.gov.br/legislacao/instrucoes/inst358.html > Acesso em: 07 nov. 2017.)
} 
controladora no Brasil, a fim de divulgar os projetos em implantação e apresentar, junto com a Companhia, a evolução dos projetos trimestralmente.

Foi, portanto, o próprio mercado que apresentou suas preocupações com o modelo de negócios da companhia e a fez aprimorar os seus padrões de divulgação de informação.

Percebe-se que, nestes casos, a autorregulação desempenha seu papel primordial, cabendo ao mercado avaliar a moralidade daquelas operações e sua consequência para a companhia, levando à sua desvalorização ou não. 


\section{CONCLUSÃO}

Como se pôde perceber ao longo desta monografia, a prática de exploração direta de oportunidades comerciais por acionistas controladores de companhias abertas brasileiras nem sempre será prejudicial à companhia controlada.

A interpretação de que, com base no dever de lealdade dos acionistas controladores, contido no art. 116, parágrafo único, da LSA, estariam os acionistas controladores proibidos de explorar quaisquer oportunidades por eles recebidas que sejam congruentes com o objeto social da companhia controlada carece de fundamento, seja porque (i) o legislador intencionalmente deixou a usurpação de oportunidade comercial fora das hipóteses de abuso do poder de controle; seja porque (ii) o dever de lealdade esperado de acionistas controladores não é o mesmo imposto como dever fiduciário aos administradores.

A doutrina majoritária brasileira e os últimos julgados da Comissão de Valores Mobiliários sobre o assunto vêm importando de forma equivocada a corporate opportunity doctrine americana, partindo do pressuposto que os acionistas controladores, no Brasil, desempenham o mesmo papel dos administradores nos Estados Unidos.

Apesar de estarem obrigados a atuar no interesse social, fazendo a companhia desempenhar o seu objeto e função sociais com respeito aos interesses dos acionistas minoritários, aos que trabalham na empresa e qualquer pessoa que tenha relação com ela, os acionistas controladores possuem liberdade para decidir a forma de exploração das oportunidades a eles pertencentes. Como atividade pertencente ao controlador, pode-se entender qualquer atividade que tenha a ele sido diretamente oferecida ou por ele desenvolvida.

A vedação à utilização de oportunidades por acionistas controladores levaria à um cenário de possível inviabilização de modelos de negócios em 
um dos setores de maior crescimento e de extrema relevância para o desenvolvimento da economia real brasileira, a indústria de private equity/venture capital. Sem a possibilidade de controle de mais de uma empresa do mesmo setor não seria possível manter a diversificação de carteira necessária para o sucesso dos FIPs voltados para projetos greenfield e start-ups, congelando ou atrasando o desenvolvimento de empresas com enorme potencial de crescimento.

$\mathrm{Na}$ mesma linha, estar-se-ia diante de um potencial fechamento de capital forçado (ou inviabilização de novas aberturas de capital) de empresas já consolidadas no mercado com business model calcado em estratégias de transferência de risco, como o desempenhado pela Engie, antiga Tractebel.

Ambas as consequências seriam extremamente prejudiciais para o desenvolvimento do mercado de capitais brasileiro.

Por fim, conclui-se que a interpretação de que os acionistas controladores não estão obrigados a oferecer as suas oportunidades previamente à companhia para que estejam liberados para explorarem-nas diretamente não significa falta de proteção aos acionistas minoritários.

Conforme analisado durante este estudo, a obrigação de ampla e completa divulgação de informações a respeito das operações com partes relacionadas ou do investimento do controlador concorrente com a atividade da companhia é o método mais eficiente de proteção aos acionistas minoritários.

Considerando os riscos envolvidos no investimento em mercado de capitais e o conhecimento técnico mínimo esperado dos agentes participantes deste mercado, cabe aos investidores tomarem suas decisões de investimento de posse de todas as informações relevantes sobre determinada companhia, resultando em uma valorização ou desvalorização da companhia controlada por acionista que utiliza oportunidades do interesse de sua controlada. 


\section{BIBLIOGRAFIA}

Apud: BATALHA, Wilson de Campos. Comentários à Lei das S.A., vol. 2, p. 562 In: FILHO, Alfredo Lamy. Temas de S.A. Rio de Janeiro: RENOVAR, 2007. $450 \mathrm{p}$.

CAMPOS, Luiz Antônio de Sampaio. Conselho de Administração e Diretoria. In: LAMY FILHO, Alfredo. PEDREIRA, José Luiz Bulhões (coords.). Direito das Companhias. Rio de Janeiro: Forense, 2009. p. 1.084 -1.262 .

CARVALHOSA, Modesto. KUYVEN, Luiz Fernando Martins. Tratado de Direito Empresarial: Volume III - Sociedades Anônimas. São Paulo: Revista dos Tribunais, 2016. 1.245 p.

CARVALHOSA, Modesto. Comentários à lei de sociedades anônimas, $2^{\circ}$ volume: artigos 75 a 137. $4^{\mathrm{a}}$ ed. São Paulo: Saraiva, 2008.912 p.

CLAUDINO, Felipe Demori. BULHÕES, Francisco Simsen. A usurpação de oportunidade comercial pelo acionista controlador: uma abordagem prática. In: HANSZMANN, Felipe (Org.). Atualidades em Direito Societário e Mercado de Capitais. $1^{\mathrm{a}}$ ed. Rio de Janeiro: Lumen Juris, 2016. p. $101-123$.

COMPARATO, Fábio Konder. Ensaios e Pareceres de direito empresarial. Rio de Janeiro: Forense, 1978. 556 p.

COMPARATO, Fábio Konder. SALOMÃO FILHO. Calixto. O poder de controle na sociedade anônima. Rio de Janeiro: Ed. Forense, 2008. 597 p.

CRSFN, Recurso 12709, Rel. Johan Albino Ribeiro, Brasília, 09 nov. 2011.

CRSFN, Recurso 14047, Rel. Ana Paula Zanetti de Barros Moreira, Brasília, 27 set. de 2016. 
CRSFN, Recurso 13883, Rel. Haroldo Mavigner Guedes Alcoforado, Brasília, 19 abr. 2017.

CVM. O mercado de valores mobiliários brasileiro. 3. ed. Rio de Janeiro: Comissão de Valores Mobiliários, 2014. 376 p.

CVM, PA No RJ2004/5494, Rel. Wladimir Castelo Branco, Rio de Janeiro, 14 dez. 2004.

CVM, PAS CVM RJ2008/1815, Rel. Eli Loria, Rio de Janeiro, 28 abr. 2009.

CVM, PAS CVM RJ2012/10487, Rel. Ana Dolores Moura Carneiro de Novaes, Rio de Janeiro, 5 nov. 2013.

CVM, PAS CVM RJ2013/1840, Rel. Ana Dolores Moura Carneiro de Novaes, Rio de Janeiro, 15 abr. 2014.

CVM. PAS TA No RJ2002/1846, Rel. Eli Loria, Rio de Janeiro, 14 Jul. 2004.

Estudo A Governança Corporativa e o Mercado de Capitais, elaborado pela KPMG. $\quad 11^{\mathrm{a}} \quad$ ed. $\quad$ Disponível em $<$ https://assets.kpmg.com/content/dam/kpmg/br/pdf/2016/12/br-estudogovernanca-corporativa-2016-2017-11a-edicao-final.pdf $>$. Acesso em 06 nov. 2017.

Estudo Consolidação de Dados - Indústria Private Equity e Venture Capital no Brasil - 2016, elaborado pela KPMG em conjunto com a ABVCAP. Disponível em <http://www.abvcap.com.br/Download/Estudos/3484.pdf>. Acesso em 06 nov. 2017.

Exposição de motivos da Lei $n^{\circ}$ 6.404/76, de 24 de Junho de 1976. Disponível em: <http://sistemas.cvm.gov.br/port/atos/leis/6404_Exposicao.asp>. Acesso em 07 nov. 2017. 
Suprema Corte de Delaware, 5 A.2d 503 Guth vs. Loft, Chief Justice Layton, 11 abr. 1939. Disponível em <https://h2o.law.harvard.edu/collages/4308>. Acesso em 07 nov. 2017

Suprema Corte de Massachusetts, 323 Mass. 187 Durfee v. Durfee \& Canning, Inc., Justice Dolan, 5 dec. 1947 - 9 jul. 1948. Disponível em <http://masscases.com/cases/sjc/323/323mass187.html>. Acesso em 07 nov. 2017.

Suprema Corte de Minnesota, 222 N.W.2d 71 Miller v. Miller, Justice Rogosheske, $20 \quad$ set. $1974 . \quad$ Disponível em: <https://law.justia.com/cases/minnesota/supreme-court/1974/437591.html>. Acesso em 07 nov. 2017.

LAMY FILHO, Alfredo. PEDREIRA, José Luiz Bulhões. Direito das Companhias. $2^{\mathrm{a}}$ ed. Rio de Janeiro: Forense, 2017. 1.680 p.

LAMY FILHO, Alfredo. PEDREIRA, José Luiz Bulhões. A lei das S.A.: (pressupostos, elaboração, aplicação). Rio de Janeiro: Renovar, 1997. 508 p.

LAMY FILHO, Alfredo. Temas de S.A. Rio de Janeiro: RENOVAR, 2007. $450 \mathrm{p}$.

MARTINS, Fran. Direito Societário: estudos e pareceres. Rio de Janeiro: Ed. Forense, 1984. 332 p.

PEREIRA NETO, Caio Mário da Silva. CASAGRANDE, Paulo Leonardo. Direito Concorrencial. São Paulo: Saraiva, 2016. 512 p.

SANTOS, Alexandre Pinheiro dos. OSÓRIO, Fábio Medina. WELLISCH, Julya Sotto Mayor. Mercado de Capitais - Regime Sancionador. São Paulo: Saraiva, 2012. 295 p.

SILVA, Thiago Mascarenhas de Souza e. O Controle Societário nas Companhias com Investimentos de Fundos de Private Equity Listadas na 
BM\&FBOVESPA. São Paulo, 2010. 160 p. Tese - Escola de Direito de São Paulo da Fundação Getúlio Vargas.

SLAUGHTER, James C. The Corporate Opportunity Doctrine. Disponível em:

$<$ http://scholar.smu.edu/cgi/viewcontent.cgi?article=4215\&context=smulr $>$. Acesso em 07 nov. 2017.

SPAMANN, Holger. Guth v. Loft (Del. 1939) [Pepsi]. Disponível em: https://h2o.law.harvard.edu/collages/4308. Acesso em 07 nov. 2017.

O'KELLEY, Charles Rogers Taber. THOMPSON, Robert B. Corporations and other business associations: cases and materials. $3^{\mathrm{a}}$ ed. Apen Law \& Business: Nova Iorque, 1999. 1.233 p.

TALLEY, Eric e HASHMALL, Mira. The corporate opportunity doctrine. U.S.C. Institute for Corporate Counsel: Los Angeles, 2001. 28 p.

TRINDADE, Marcelo. Processo Sancionador na CVM: Limites e Possibilidades. In: VENANCIO FILHO, Alberto; LOBO, Carlos Augusto da Silveira; ROSMAN, Luiz Alberto Colonna (orgs.). Lei das S.A. em seus 40 anos. $1^{\mathrm{a}}$ ed. Rio de Janeiro: Forense, 2017. p. $481-500$.

YING, Jennifer. Guth v. Loft: The Story of Pepsi-Cola and the Corporate Opportunity Doctrine. Disponível em: $<$ https://papers.ssrn.com/sol3/papers.cfm?abstract_id=1414478>. Acesso em 07 nov. 2017. 